
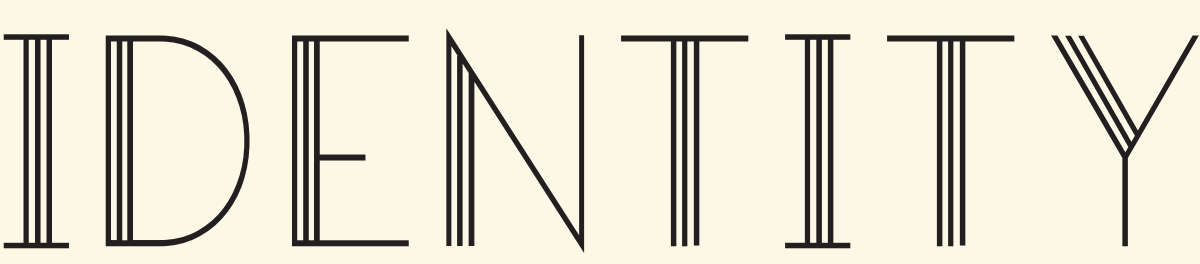

Understanding Aspects of Process, Content, and Structure in Context

\title{
Fanny Gyberg
}




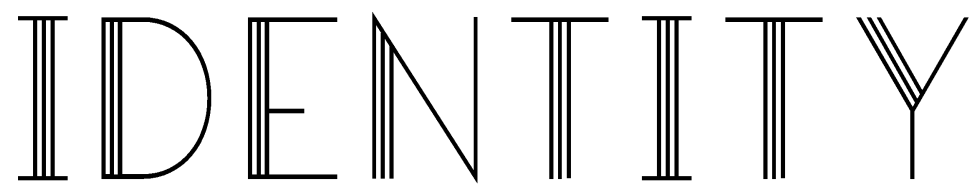

Understanding Aspects of Process, Content, and Structure in Context 
Doctoral Dissertation in Psychology

Department of Psychology

University of Gothenburg

November 8, 2019

\section{(C) Fanny Gyberg}

Cover art: Camia Pia

Cover layout: Camia Pia

Printing: BrandFactory AB, Kållered, Sweden, 2019

ISBN: 978-91-7833-624-1 (Print)

ISBN: 978-91-7833-625-8 (PDF)

ISSN: 1101-718X Avhandling/Göteborgs universitet, Psykologiska inst.

http://hdl.handle.net/2077/61799 
We contain multitudes. 



\section{ABSTRACT}

Gyberg, F. (2019). Identity: Understanding aspects of process, content, and structure in context. Department of Psychology, University of Gothenburg, Sweden.

The overall aim of this thesis was to broaden our knowledge of identity by using an integrated theoretical approach to understanding multidimensional aspects of identity process, content, and structure. Specifically, in Study I, the aim was to investigate identity processes among young adults in Sweden by studying identity status (i.e., varying degrees of exploration and commitment to identity-defining issues) globally and across domains (i.e., occupation, romantic relationships, parenthood, and work/family priorities). In addition, differences in social comparison between identity statuses were investigated. The results indicated that most of the 124 participants (50\% women, $M_{\text {age }} 33.29$ years) had made identity-defining commitments, and gender differences in identity status were found in the occupational and parenthood domains. In addition, differences in social comparison orientation were found only in the parenthood domain, where those actively exploring without making commitments scored higher in social comparison than did those who had not explored this domain. The aim of Study II was to investigate identity content by studying what types of ethnicity-related experiences were prevalent among young people in Sweden with and without an immigrant background (i.e., at least one parent born outside Sweden). Using a narrative approach, 95 participants $\left(87 \%\right.$ women, $66 \%$ with an immigrant background, $M_{\text {age }}=19.62$ ) shared their ethnicity-related experiences. Through thematic analysis, we found six themes for which most of the related narratives were about struggling to adapt and fit in, regardless of age, ethnicity, or immigrant status. In Study III, the aim was to investigate identity structure by studying how young adults in Sweden negotiated their sometimes conflicting multiple identifications of occupation and family into different types of identity configurations. Six different types of identity configurations were found among the participants (the same sample as in Study I) varying conceptually on two dimensions: 1) choosing or not choosing one identification over another and 2) level of certainty, ambivalence, or discrepancy in prioritizing between work and family. Few gender differences were found across the identity configurations. The quantitative analyses indicated differences in the degree of internal conflict and life satisfaction between different identity configurations. In sum, this thesis emphasizes the complexity of identity development and the importance of cultural context in obtaining a multidimensional understanding of aspects related to the process, content, and structure that constitute identity.

Keywords: identity development, identity process, identity content, identity structure, gender, ethnicity, cultural context 



\section{SVENSK SAMMANFATTNING (SWEDISH SUMMARY)}

Vem är du? Svaret på den frågan handlar om olika aspekter av din identitet. Det kan vara vem du är i din yrkesroll, vem du är som partner, vem du är som förälder och vem du är i relation till din etniska tillhörighet. Allt detta och mer därtill gör att du är du och jag är jag. De områden i livet som är viktiga för vår identitet varierar mellan oss och skiljer sig åt under olika faser i livet. Vilka vi är präglas också av de olika sammanhang vi befinner oss i, även kallat kontexter. Kontext kan exempelvis handla om var du bor, var du arbetar eller går i skolan, samt hur din familj och din vänskapskrets ser ut. I studierna som utgör denna avhandling fokuseras det på det kulturella sammanhang vi som lever i Sverige befinner oss i, det vill säga den svenska kontexten. Sverige är ett ganska speciellt land i relation till resten av världen när det handlar om kulturella värden och värderingar. Exempelvis lägger människor i Sverige generellt sett stor vikt vid självförverkligande, frågor om miljö samt frågor om jämlikhet och mindre vikt vid traditionella värderingar vad gäller könsroller, familjeroller och religion. Sverige anses även vara ett av världens mest jämställda länder och ett land med integrationsvänliga policyer. Även om dessa normer och värderingar i det svenska samhället inte upplevs av alla människor på ett individuellt plan, så är det troligt att de på olika sätt påverkar vilka vi är - det vill säga hur vi tar oss an frågan Vem är jag?.

Det finns flera olika sätt att närma sig och förstå begreppet identitet, liksom det finns olika sätt att måla av ett landskap - där en konstnär fokuserar på himlens färgskiftningar och en annan på haren som skuttar över fälten. Ändå porträtterar de båda konstnärerna samma landskap. I denna avhandling var det övergripande syftet att på olika sätt studera identitet hos människor i Sverige, inom olika områden och under olika faser i livet för att på så vis få en ökad förståelse och kunskap om några av de aspekter som ryms i svaret på frågan: Vem är du?

Ett sätt att förstå identitetsskapandet är att undersöka processer kopplade till identitetsutveckling, till exempel i vilken grad människor utforskar och tar ställning till frågor som är viktiga för deras identitet. Genom att studera individers grad av utforskande och ställningstagande så är det också möjligt att se vilken typ av identitetsskapande, så kallad identitetsstatus, de ger uttryck för. Det finns fyra olika typer av identitetsstatus: ställningstagande efter att ha utforskat olika alternativ viktiga för identiteten (uppnådd identitet), ställningstagande utan att ha utforskat olika alternativ viktiga för identiteten 
(för tidig identitet), aktivt utforskande av olika alternativ viktiga för identiteten utan att ha tagit ställning (moratorium) och frånvarande eller vagt ställningstagande och utforskande av frågor viktiga för identiteten (diffus identitet).

I Studie I var syftet att undersöka dessa identitetsskapande processer hos kvinnor och män i trettioårsåldern, både generellt och inom viktiga identitetsområden såsom yrke, relationer, föräldraskap och prioriteringar mellan yrke och familj. Således undersökte vi hur vanliga olika identitetsstatus var bland 62 kvinnor och 62 män samt om det fanns några könsskillnader $\mathrm{i}$ identitetsstatus både generellt och inom olika identitetsområden. Vi undersökte också om det fanns något samband mellan deltagarnas olika identitetsstatus och hur mycket de jämförde sig med andra människor, så kallad social jämförelse.

Resultaten visade att majoriteten av deltagarna hade utforskat och tagit ställning till viktiga identitetsfrågor både generellt och inom specifika identitetsområden. Vidare pekade resultaten på att även om det fanns något fler likheter än skillnader i identitetsstatus mellan kvinnor och män så kan identitetsskapandet se olika ut inom vissa identitetsområden. Vi fann att fler kvinnor än män hade utforskat innan de tog ställning till frågor rörande yrke och föräldraskap. När det kom till relationen mellan identitetsstatus och i vilken utsträckning deltagarna jämförde sig med andra fann vi få samband. Det enda samband vi fann mellan identitetsstatus och social jämförelse var inom området föräldraskap. Mer specifikt fann vi att de som aktivt utforskade frågor om föräldraskap jämförde sig mer med andra än de som inte hade utforskat dessa frågor.

Sammantaget belyser resultaten från Studie I vikten av att studera processer relaterade till identitet inom olika identitetsområden, då identitetsskapandet inom dessa kan se olika ut beroende på kön. Fynden, att kvinnor utforskat identitetsbärande frågor relaterade till yrke och föräldraskap i högre grad än män, kan spegla de kulturella normer och förväntningar som finns på kvinnor och män i Sverige.

Ett annat sätt att förstå identitetsskapandet är att undersöka själva innehållet i identiteten, där individens berättelse om sig själv står i fokus. Detta synsätt kännetecknas av att identiteten formas och ges mening genom de berättelser vi skapar om oss själva, om vår omvärld och om våra erfarenheter. Dock skapas berättelsen om oss själva inte i ett vakuum. I den kulturella kontext vi befinner oss i finns det tongivande berättelser om vad det exempelvis innebär att vara svensk vilket ofta påverkar vår egen personliga berättelse. När våra personliga berättelser inte stämmer överens med den kulturella berättelsen brukar detta göra identitetsskapandet särskilt påtagligt eftersom vi behöver förklara och 
förstå dessa skillnader. Att inte kunna känna sig hemma i de normer och förväntningar som finns inom en kultur kan således vara psykologiskt påfrestande. Forskning har dock visat att människor, som skiljer sig från den kulturellt tongivande berättelsen om vad som är förväntat och accepterat, ofta skapar en egen berättelse innehållandes positiva element av stolthet och samhörighet med andra personer som också skiljer sig från normen.

I Studie II var syftet att förstå innehållet i unga individers etniska identitet, det vill säga den del av identiteten som är kopplad till etnisk tillhörighet. Således undersökte vi vilka typer av erfarenheter relaterade till etnicitet som unga i Sverige hade och om dessa erfarenheter skilde sig åt beroende på åldersgrupp (tonåringar och unga vuxna) och etnisk tillhörighet (svensk, annan än svensk, svensk och annan än svensk) och utländsk bakgrund (minst en förälder född utanför Sverige). Gymnasieelever och universitetsstudenter fick skriftligen beskriva erfarenheter, när de upplevt att deras syn på sig själva (deras berättelse) hade skiljt sig från vad som anses normalt, förväntat eller accepterat (den kulturellt tongivande berättelsen).

Av de 437 berättelser som samlades in handlade 95 (22\%) av dem om erfarenheter kopplade till etnicitet. Vi fann att berättelser om etnicitet var vanligare hos kvinnor med utländsk bakgrund än hos andra. När vi undersökte deltagarnas berättelser om erfarenheter kopplade till etnicitet så fann vi sex typer av berättelser. Den vanligaste typen av berättelse var om diskriminering och rasism, där erfarenheterna handlade om att utsättas för, eller se andra utsättas för, rasism, fördomar och diskriminering. Vanligt förekommande var också berättelser om generella skillnader, vilket oftast handlade om att se kulturella skillnader mellan sig själv och andra. Ytterligare ett tema var att vara en annan sorts svensk, där berättelserna handlade om att känna sig som svensk men inte bli sedd som svensk av andra, eller det motsatta, att bli sedd som svensk av andra men själv inte känna sig som svensk. Ett annat tema var distansering till kultur eller etnicitet, där berättelserna handlade om att aktivt ta avstånd från aspekter kopplade till den etniska bakgrund individen helt eller delvis tillhörde. Vidare fann vi berättelser på temat att vara mittemellan kulturer/etniska tillhörigheter, där deltagarna berättade om att inte veta vilken etnisk tillhörighet de hade, där de upplevde det som att de befann sig i en gråzon eller ett ingenmansland. Ett ytterligare tema var kulturella ideologier, där deltagarna delade med sig av mer åsiktsbaserade berättelser om alla människors lika värde. Vi fann att det var vanligare att tonåringar skrev om att vara en annan sorts svensk än vad unga vuxna gjorde. Däremot så påverkade varken etnisk tillhörighet eller om individerna hade en utländsk bakgrund vilken typ av berättelse de berättade.

Sammantaget belyser resultaten från Studie II vikten av att studera innehållet $\mathrm{i}$ unga individers identitet där erfarenheterna deltagarna delade med sig av ofta handlade om att inte passa in i det svenska samhället på grund av 
sin etniska bakgrund. Det var främst negativa berättelser som berättades om att inte passa in vilket kan skapa en känsla av utanförskap som i sin tur kan få psykologiska konsekvenser. Sådana konsekvenser kan antas påverka identitetsskapandet på ett negativt sätt.

Ett tredje sätt att förstå identitetsskapandet är att studera hur människor strukturerar sina olika delar av identiteten till en fungerande helhet. Ibland kan olika områden stå i konflikt med varandra, till exempel kan det vara svårt att få ihop att vara förälder, partner och att göra karriär. Att integrera olika identitetsområden till en fungerande helhet handlar inte enbart om att få ihop sin tid och sin planering; det handlar också om hur vi strukturerar de olika delarna inom oss och hur viktiga de är för vilka vi är som individer. Det finns med andra ord olika sätt att strukturera sin identitet på. För en individ kan exempelvis vem hen är som förälder vara mycket viktigare än vem hen är i sin yrkesroll, medan det för en annan individ är helt tvärt om och där en tredje individ kan ha flera områden, som är precis lika viktiga för vem hen är, exempelvis att vara både mamma och ingenjör.

I Studie III var syftet att förstå hur individer i tidiga vuxenåren strukturerar sina identiteter inom olika områden till en fungerande helhet. Närmare bestämt undersöktes hur individer strukturerade de delar av identiteten som är kopplade till yrkesroll och familjeroll. Vi studerade också om det fanns könsskillnader i de olika sätt kvinnor och män strukturerade sina identiteter. Vidare undersökte vi eventuella samband mellan hur deltagarna strukturerade sina identiteter och graden av inre konflikt de uttryckte via intervjuer, samt hur de skattade sin tillfredsställelse med livet.

Vi fann sex olika sätt som deltagarna strukturerade sina yrkes- och familjeidentiteter på. Vanligaste sättet deltagarna strukturerade sina identiteter på var att se familj som det viktigaste för vilka de var som individer (1). Yrke ansågs av dessa deltagare enbart vara ett sätt att försörja sig på. Vanligt förekommande var också att uttrycka att både yrke och familj var lika viktiga delar av identiteten (2), där dessa deltagare ofta förklarade det som att de ville "maxa allt". Det fanns också många deltagare, som trots att de ansåg att en del av identiteten var viktigare än en annan, tampades med att förverkliga detta $\mathrm{i}$ vardagen (3). Ofta handlade det om att de uttryckte att familj var det mest identitetsbärande området, men att de ändå ägnade den mesta tiden åt att arbeta. Färre deltagare lyfte fram att både yrke och familj var viktiga för vilka de var som individer, men där de uppgav att de hade satt yrkeslivet och karriären på paus (4). Ofta beskrev dessa deltagare att de hade valt att gå in helt i familjerollen för att de nyligen ingått romantiska relationer eller just skaffat barn. Vissa av deltagarna beskrev att de hade svårare att strukturera sina yrkesoch familjeidentiteter (5). Flera av dessa deltagare tycktes inte ha reflekterat 
över hur de balanserade de olika delarna av identiteten. För somliga kunde detta bero på att ingen av dessa identitetsområden betydde särskilt mycket för dem som individer. Det minst vanliga sättet att strukturera sina identiteter på var att beskriva yrke som den viktigaste delen av identiteten (6). Att se yrke som det mest identitetsbärande området var också den enda identitetsstrukturen där vi fann en könsskillnad, då detta mönster endast återfanns hos männen. När vi undersökte relationen mellan identitetsstruktur och upplevd grad av inre konflikt fann vi att de deltagare där familjeidentiteten var det viktigaste (1), uttryckte lägre grad av inre konflikt än de deltagare där allt var viktigt (2), de deltagare som tampades med att prioritera i vardagen utefter hur de kände inombords (3), samt de deltagare där allt var viktigt men karriären var satt på paus (4). De deltagare som hade svårt att strukturera sina yrkes- och familjeidentiteter (5), samt de deltagare där yrkesidentiteten var viktigast (6), uttryckte mindre inre konflikt än de deltagare som tampades med att prioritera i vardagen utefter hur de kände inombords (3). När vi sedan analyserade eventuella samband mellan identitetsstruktur och grad av tillfredsställelse med livet, fann vi att de deltagare som fann både yrke och familj lika viktigt (2), rapporterade högre grad av livstillfredsställelse än de deltagare som hade svårt att strukturera sina yrkes- och familjeidentiteter (5), samt de deltagare där yrkesidentiteten var viktigast (6).

Sammantaget belyser resultaten från Studie III vikten av att studera hur identiteten struktureras eftersom de olika sätt vi strukturerar våra identiteter på kan se olika ut för olika individer. De sätt individer strukturerar sina identiteter på tycks också vara beroende av den kulturella kontext de lever i. Vidare indikerar resultaten att en högre grad av upplevd konflikt mellan olika delar av identiteten inte nödvändigtvis behöver påverka livstillfredsställelsen på ett negativt sätt.

De sammantagna resultaten i denna avhandling visar på hur komplext identitetsskapandet är och hur viktigt det är att fånga olika dimensioner av identitet (process, innehåll, struktur), när vi försöker förstå vad identitet är. Vidare är det viktigt att betona vikten av att ta hänsyn till den kulturella kontext vi lever i då kulturella normer och förväntningar påverkar vår bild av oss själva. I denna avhandling lyfts också betydelsen av att tillåtas och få utrymme att vara "många" - att exempelvis få vara både svensk och iranier, både mamma och ingenjör. Att få vara "många" kan liknas vid att ha flera olika krokar att hänga upp våra identiteter på. Sammanfattningsvis belyser de sammantagna studierna värdet av att studera identitet på flera olika sätt, inom olika identitetsområden och under olika faser av livet. Genom att integrera teorier och metoder kan vi få en ökad förståelse för de aspekter som ryms i svaret på frågan: Vem är $d u$ ? 



\section{LIST OF PUBLICATIONS}

This thesis consists of a summary and the following three papers, which are referred to by their roman numerals:

I. Gyberg, F., \& Frisén, A. (2017). Identity status, gender, and social comparison among young adults. Identity, 17, 239-252. doi:10.1080/15283488.2017.1379905

II. Gyberg, F., Frisén, A., Syed, M., Wängqvist, M., \& Svensson, Y. (2018). "Another kind of Swede": Swedish youth's ethnic identity narratives. Emerging Adulthood, 6, 17-31. doi: $10.1177 / 2167696817690087$

III. Gyberg, F., Frisén, A., \& Syed, M. (2019). “Being stuck between two worlds": Identity configurations of occupational and family identities. Provisional acceptance in Identity.

Studies I and III were financially supported by a grant from the Research Council for Health, Working Life and Welfare (Forskningsrådet för Hälsa, Arbetsliv och Välfärd, FORTE) awarded to Professor Ann Frisén, University of Gothenburg, Sweden. 



\section{ACKNOWLEDGEMENTS}

"Who am I?" is the question that sparked this thesis. For me, I would not be the person, daughter, lover, friend, student, or researcher that I am today without all the incredible people I am fortunate to have in my life. You see, as we all contain multitudes, this thesis also contains multitudes. It would not have been written without the tremendous support I've received from the people around me. For that, I am eternally grateful.

First, I would like to thank my supervisor Ann Frisén for her valuable guidance and for making it possible for me to follow my longtime dream of studying identity. I also want to thank my second supervisor, Moin Syed, for all the encouragement, inspiring me to think bigger and broader. I am very fortunate to have had both as my supervisors. In addition, I want to acknowledge my examiner for the first two years of this research, Tomas Tjus, who has sadly passed away: his warmth and sunny view of life are things I will always remember. Inga Tidefors is thanked for all her support and guidance, both academically, as a stand-in examiner, and at a more personal level as a friend. Thanks are also due to Jan Johansson Hanse for taking on the examiner role in the last crucial year of thesis work, with both interest and meticulous precision.

I also want to thank additional people who helped make this thesis better: Margareta Bohlin and Monica Martinussen for their insightful thoughts on a partial version of this thesis; Kjerstin Almqvist for her detailed, consistent, and insightful comments on an earlier version of this thesis; and Ann Backlund for all her support and guidance throughout my years as a doctoral student.

A big thanks is expressed to my colleagues in the GReY research group for all the interesting discussions, companionship at conferences, and great fika moments: a special thanks to Jonas Burén for all the tea breaks, car rides, and chats about many more or less important matters of life; to Johanna Kling, Ylva Svensson, and Maria Wängqvist for the great collaboration and much-needed support during these years; and to Carolina Lunde for taking me under her wing from the get-go - she has truly been an inspiration.

Mentioning all my other friends and colleagues at the department would be a thesis in itself, and I thank them for giving me strength and motivation: I am 
forever grateful for all our conversations, whether over lunch, a cup of coffee, or a glass of wine. There are nonetheless a few people I would like to acknowledge specifically. I would like to extend special thanks to Elin Alfredsson, Karin Boson, Sara Ingevaldson, Johan Melander Hagborg, and Karin Wallgren Thorslund for being my life rafts throughout the research process: it has meant the world to have them by my side through all the tears and laughter. I thank Emelie Ernberg for always being there, ready to take on anything, whether concerning research projects, new courses, world domination, or simply everyday matters. Thanks to Lisa Rudolfsson and Elisabeth Punzi for all the jävlaranamma, love, and support, to Kerstin Adolfsson for always having a positive take on things, to Sandra Buratti for not having so, and to Jennifer Strand for trusting me to be her lecturer sidekick. Thanks are also due to my former roommate Isabelle Hansson for being a perfect match in terms of levels of neuroticism and perfectionism. Finally, I acknowledge Leif Strömwall for all his help and encouragement, whether concerning methodological issues or issues of self-doubt, or for simply sharing obscure facts on popular culture.

Also, I would like to acknowledge some people on "the outside." Thanks to Gotlandsgänget - although we do not see each other that often, our rendezvous when on öjn mean the world to me. A special thanks to Nina Engelbrektsson and Anita Tarverdi for being there, through thick and thin, with endless love and good humor. Thanks also to all the kids and leaders in Passalen for keeping me grounded and giving me perspective on the things important in lifespending the weekends with them has given me the strength and energy to move forward.

I would also like to express my sincere gratitude to all the participants in the three studies for so generously sharing their stories.

Finally, my largest thank you goes to my huge crazy, wonderful, mildly psychotic, warm, loving, and highly dysfunctional family, without whom I never would have turned to the field of psychology to begin with. ILY! And $J a k o b$, there are no words describing what you have meant to me during this process, both emotionally and for making it possible for me to have it all: working intensely on my thesis as well as being a mother to the love of our lives, Assar.

Fanny Gyberg, Gothenburg, October, 2019 


\section{CONTENTS}

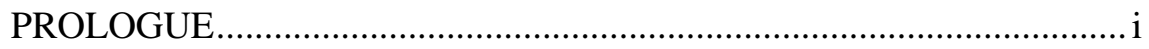

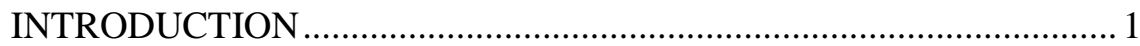

The Cultural Context of Sweden .................................................................. 1

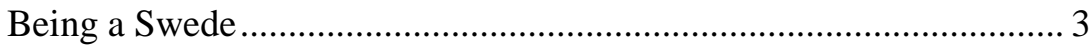

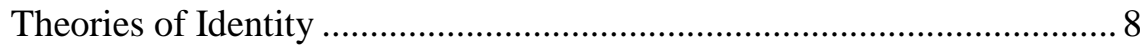

Integrating Theories and Applying a Multidimensional Approach.... 11

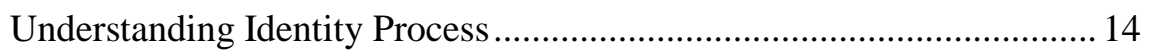

Identity Status Model ................................................................ 14

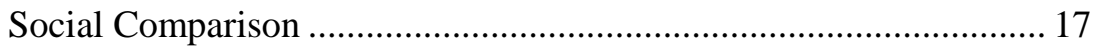

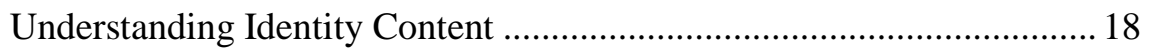

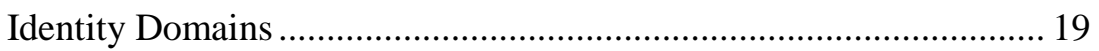

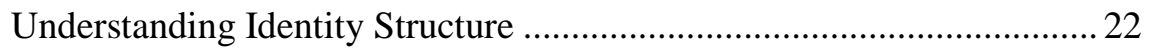

Identity Configurations ............................................................... 23

Challenges in Understanding Identity Process, Content, and Structure .. 25

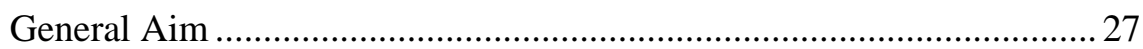

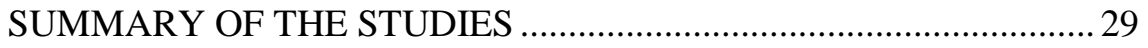

The GoLD Project ……………………………….............................. 29

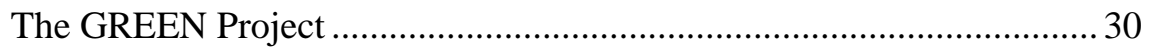

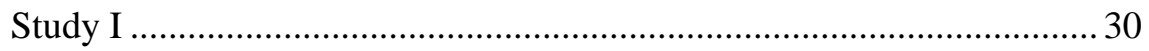

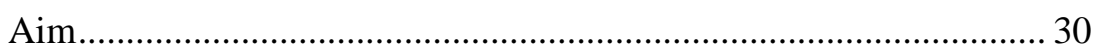

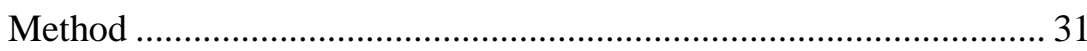

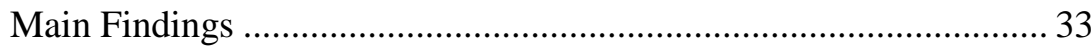

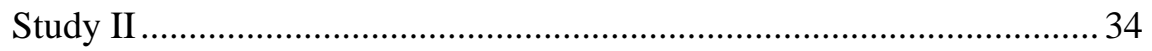

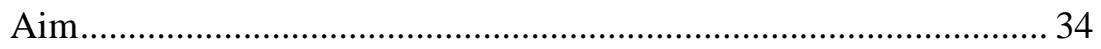

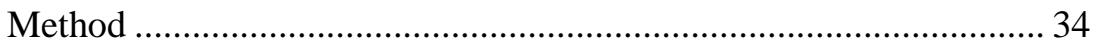

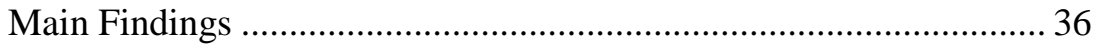

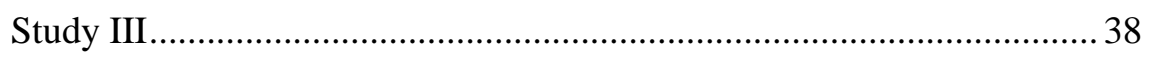




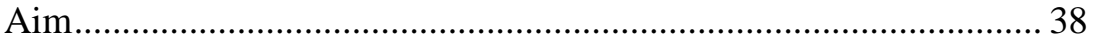

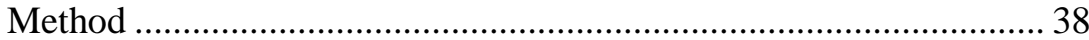

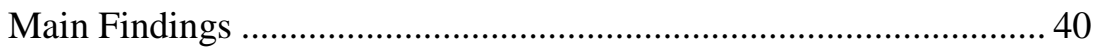

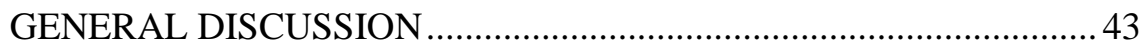

Discussing Identity Process ....................................................................... 43

Identity Status and Gender ................................................................ 44

Social Comparison and Identity ......................................................... 45

Implications and Future Directions ................................................... 47

Discussing Identity Content ................................................................ 48

Ethnic Identity Content in Sweden..................................................... 48

For Whom is Ethnic Identity an Important Domain?......................... 51

Implications and Future Directions ……………….......................... 52

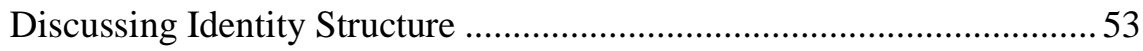

Identity Configurations of Occupational and Family Identities ......... 53

Implications and Future Directions ................................................... 56

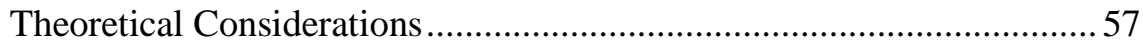

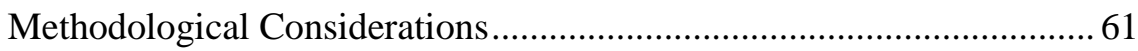

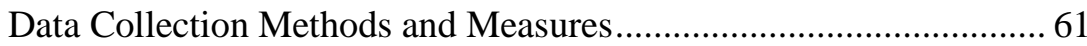

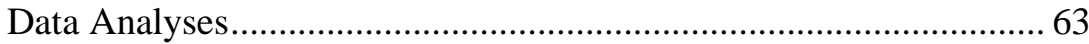

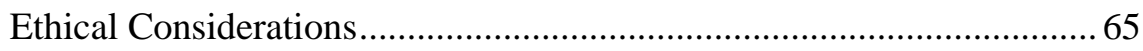

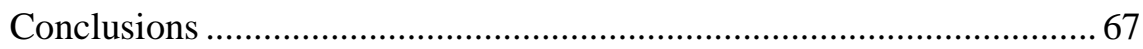

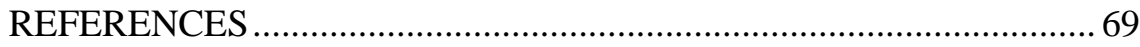

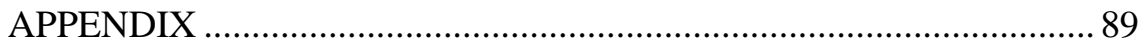




\section{PROLOGUE}

For, indeed, in the social jungle of human existence, there is no feeling of being alive without a sense of identity.

Erik H. Erikson

Identity is integral to our lives as human beings. In fact, few aspects of our lives are as fundamental as the sense of identity, as emphasized in the above quotation from Erikson (1968, p. 130). Stemming from the Latin word idem, which means being the same, identity may be defined as the notion of being the same - in the past, present, and future (Erikson, 1956, 1968). Identity therefore concerns the conception of remaining the same while being different from all other human beings in the world. One could say that identity is what answers the fundamental question "Who am I?"

Identity is something to which we all must relate, in one way or another, regardless of our own personal answers to the question "Who am I?" Identity may be seen both as a whole, a global concept, and as the combination of our identities in the various identity-defining areas of life (also called identity domains), for example, who we are in relation to our ethnic group, at work, as partners, and as parents. Identity is a developmental process that comes to the fore in adolescence and continues throughout the lifespan, during which the importance of various identity domains, such as occupation, romantic relationships, parenthood, and the balance between them, varies between ages and contexts. Although many contexts, for example, social contexts (e.g., peers and family), are important to who we are, this thesis focuses on personal identity from a broader cultural context perspective.

Not only can we consider different domains when studying identity, but we can also adjust our focus when studying its different dimensions. We could concentrate on the processes that identity formation entails, such as the processes of identity exploration and commitment. We can set our focus on the specific content of which identity is made, such as everyday experiences. Also, we can consider how we structure our identities, such as our occupational and family identities, to form a reasonably workable whole. This thesis examines 
several aspects of identity process, content, and structure to obtain a more multidimensional understanding of the inherent complexity of identity, which calls for multiple perspectives. As identity is a universal aspect of life, several theories and schools of thought address what forms and constitutes it. This thesis treats three theories of identity. The main theory used in all three appended studies is Erikson's theory of identity development (Erikson, 1950, 1956, 1968, 1980), the second, building on Erikson's work, is narrative identity theory (McAdams, 1993, 2001, 2011, 2015), which is addressed in studies II and III, and finally, the third is social identity theory (Tajfel \& Turner, 1979, 1986), which is addressed in limits I and II.

As mentioned, three studies are included in this thesis. Study I treats aspects of identity process by examining identity status ${ }^{1}$ in different identity domains among young adults, investigating potential gender differences and their relationships to social comparison. In Study II, the identity content of ethnic identity is studied by investigating ethnicity-related experiences narrated by adolescents and emerging adults, with and without immigrant background (i.e., at least one parent born outside Sweden). Last, identity structure is studied in Study III by examining how young adults configure their multiple identifications of occupational and family identities into a workable whole, with potential gender differences and possible associations with perceived conflict and life satisfaction being investigated.

The first section of this thesis introduces cultural context, as it is the area where identity acts and is therefore crucial for our understanding of what constitutes the answer to the fundamental question "Who am I?" In addition, age-specific matters relevant to the Swedish cultural context will be highlighted to shed light on the various developmental aspects relevant to identity development. The succeeding sections concern theories of identity, followed by the identity dimensions of process, content, and structure. Lastly, the three studies are summarized, followed by a general discussion of the main findings and important considerations. Overall, this thesis aims to broaden our knowledge of identity by using a theoretically integrated approach to understanding multidimensional aspects of the process, content, and structure involved in identity development.

\footnotetext{
${ }^{1}$ Identity status is defined according to Marcia's (1966) conceptualization of the identity processes of exploration and commitment.
} 


\section{INTRODUCTION}

Identity is not created in a vacuum, and who we are may also be viewed as reflecting the larger cultural environment (Azmitia, 2015; Erikson, 1968; Fivush \& Zaman, 2015; Galliher, McLean, \& Syed, 2017a; Hammack, 2008; McLean et al., 2018). It is therefore essential to understand the cultural context in which identity is situated. The norms and values of a particular cultural context will likely affect how identity issues are dealt with, as identity is formed in interaction between the internal and external worlds (e.g., Erikson, 1968; McAdams, 2001; Tajfel \& Turner, 1979). It is therefore important to understand the cultural context of Sweden, as it is the backdrop for the identity studies included in this thesis. The following describes cultural values, gender aspects, and ethnicity in Sweden to highlight the contextual features important for the three appended studies.

\section{The Cultural Context of Sweden}

Situated in Northern Europe, the fifth largest country by area and the fifth least densely populated country in Europe, Sweden is an interesting country to study. Although a relatively small country in global terms, Sweden is known by many people around the world for its political neutrality, gender equality, and social welfare system, often referred to as the "Swedish model" (see, Berggren \& Trägårdh, 2011; Towns, 2002; Trägårdh, 1990). According to the World Values Survey (WVS, 2015), which measures aspects of culture in about 100 countries worldwide, people in Sweden have been found to have the highest self-expression values and the second highest secular-rational values relative to people in other countries (see Figure 1). Self-expression values refer to prioritizing environmental protection, participation in decision-making concerning economics and politics, and values of equality regarding gender, sexuality, and ethnicity. Secular-rational values refer to placing less importance on religion, traditional family values, and authority. 


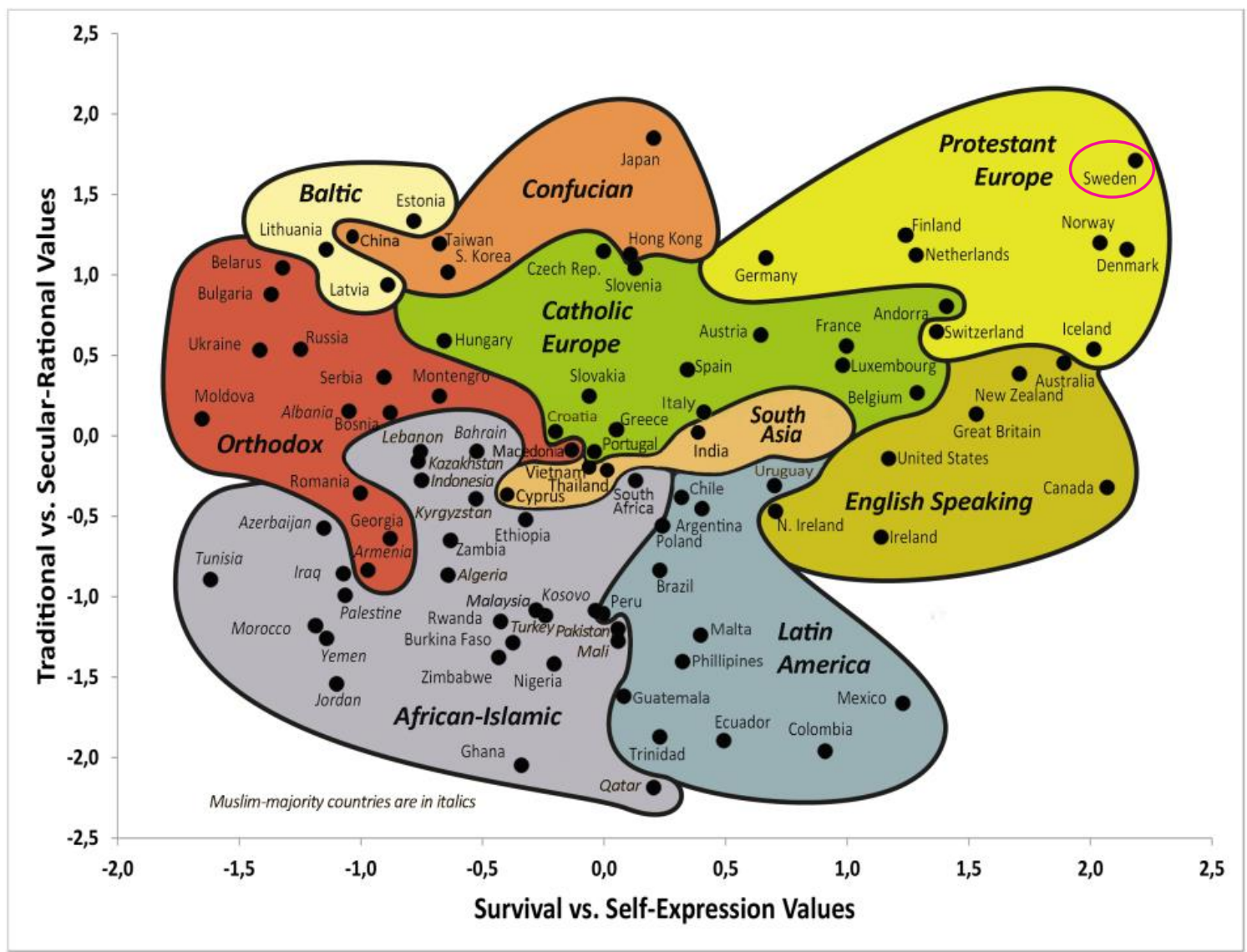

Figure 1. Inglehart-Welzel cultural map (WVS, 2015); Sweden indicated with a circle by the author of this thesis). 
Swedes themselves often view Sweden as like most other countries, with a strong notion of being lagom, a Swedish word meaning "just right" or "just enough" (e.g., Almqvist, 2006; Moon, 2008). In reality, as shown in Figure 1, Sweden and its inhabitants in many respects constitute an extreme compared with the rest of the world (WVS, 2015). As the values and beliefs of a society are likely integrated into personal identity (Galliher et al., 2017a; Hammack, 2008, 2011; McAdams \& Zapata-Gietl, 2015; McLean et al., 2018; Rogers, 2018; Schachter, 2005a), these cultural values may affect how identity is expressed in the Swedish context.

\section{Being a Swede}

\section{Gender Values}

Sweden is often referred to as one of the most gender-equal countries in the world (European Institute of Gender Equality, 2017; World Economic Forum, 2018). Compared with many other countries, Swedes conform less to traditional gender role norms (Holmqvist Gattario et al., 2015; Kling, Holmqvist Gattario, \& Frisén, 2017; Stavrova, Fetchenhauer, \& Schlösser, 2012). In other words, the ideological norms of gender equality in Sweden are reflected in the many policies and laws in favor of living lives as genderequally as possible. For example, both parents are encouraged to take parental leave and are expected to share responsibilities for work and family (Almqvist, Sandberg, \& Dahlgren, 2011; Duvander, 2014; Haas \& Hwang, 2000; Johansson \& Klinth, 2008; Sommestad, 1997). More explicitly, through the Swedish parental leave program, parents can receive a parental benefit that enables them to stay at home and take care of their child (Swedish Social Insurance Agency, 2018). This benefit is paid for 240 days for each parent. However, one parent can decide to transfer all except 90 of his or her days to the other parent. Having 90 reserved and non-transferrable days is intended to encourage both parents to care for their child and have the role of family provider. In practice, however, only $14 \%$ of families share parental leave equally, as mothers take approximately $72 \%$ and fathers $28 \%$ of the leave days (SCB, 2018; Swedish Social Insurance Agency, 2018). The norm of gender equality in Sweden may thus be more of an ideological aspiration than a reflection of everyday life (Magnusson, 2008; Towns, 2002). Moreover, some have argued that the parental benefit system may be more driven by childcentered norms than being an incentive for gender equality (Elvin-Nowak \& Thomsson, 2001). 
Gender role norms in a society, like the cultural values mentioned above, are also likely to be internalized and integrated into individuals' identities (Carter, 2014; Fivush \& Zaman, 2015; McLean, Shucard, \& Syed, 2017). It is therefore particularly interesting to study gender differences and similarities in the Swedish cultural context. It has been suggested that identity development may be more similar between women and men in the Nordic countries (Fadjukoff, Feldt, Kokko, \& Pulkkinen, 2019). The norm of gender equality may make gender differences less obvious in the Swedish context, which may offer more arenas for exploration for both women and men. However, the historical shift toward gender equality may have primarily affected women (England, 2010). It is women who have received greater room for exploration when it comes to occupations, for example, and although men have been given the opportunity by law to take parental leave, it is still women who take the most parental leave and have the largest responsibility for caring for children (Björnberg, 2002; Haas \& Hwang, 2019; SCB, 2018; Swedish Social Insurance Agency, 2018). Identity as related to both occupation and family is likely to be influenced by the dual-breadwinner norm in Swedish society. Taking gender into account when studying identity, regardless of the approach, may shed further light on similarities and differences in identity development between women and men, as is one of the aims of studies I and III.

\section{Ethnicity}

Another important aspect of cultural context is ethnicity (Verkuyten, 2018; Worrell, 2015). Sweden is a country that has increasingly diversified in the last several decades, with almost one out of five citizens now having been born outside of Sweden (SCB, 2019a). In Sweden, approximately 32\% of the population comes from families with at least one parent born abroad (SCB, 2019a). Historically, Sweden has had multiple waves of immigration, first from European countries and more recently from countries outside Europe (Berry et al., 2006). Whereas migrants previously mainly came from other Nordic countries, Syria is now the most common country of birth among migrants (SCB, 2019b). Sweden was previously considered to have the most generous asylum policies in the European Union (Swedish Migration Agency, 2019). However, in 2015, after a rapid increase in the entry of refugees, integration policies and severe restrictions on asylum were enacted (Schierup, Ålund, \& Nergaard, 2018; Swedish Migration Agency, 2019).

Regarding the integration of immigrants in Swedish society, Sweden has been ranked as the country with the most integration-promoting policies in the world (MIPEX, 2015). For example, rather than being forced to learn only the official national language, as is customary in many countries that stress the 
importance of assimilation, children who have migrated to Sweden are often provided with school resources to maintain their heritage language while also learning Swedish and English (Ferrer-Wreder, Trost, Lorente, \& Mansoory, 2012). However, political discussions increasingly emphasize monocultural ideals using nationalist rhetoric (e.g., Hellström \& Nilsson, 2010; Iakimova, 2018; Schierup et al., 2018; Towns, Karlsson, \& Eyre, 2014), and Sweden has even been referred to as endorsing cultural assimilation (SOU, 2005; Wickström, 2013). Although Sweden has many integration-promoting policies, this may not show in the everyday experiences of many young people with immigrant backgrounds.

Ethnicity has largely been studied from a social identity perspective, as ethnicity is often a salient group identity. Research combining the Eriksonian perspective on identity and social identity theory has increasingly explored what has been called ethnic identity (Phinney, 1990, 2000). Ethnic identity will accordingly be more thoroughly described later in this thesis, as it is the main concept investigated in Study II.

\section{Growing up in Sweden}

It is important to highlight the norms and expectations within a culture in order to understand identity development. We also need to understand how these norms and expectations may vary depending on age. ${ }^{2}$ In Sweden, as in many other affluent societies today, youth is notably prolonged (Arnett, 2015; Côté, 2019; Côté \& Allahar, 1994; Syed \& McLean, 2015), for example, with leaving home, becoming established in the labor market, and starting a family occurring much later than they did fifty years ago (e.g., Arnett, 2014; Erikson, 1980). However, it is important to acknowledge that there may be age differences in these role transitions due to, for example, socioeconomic status, urban versus rural context, cultural background, and family situation. The following are brief general descriptions of the developmental phases relevant to this thesis, as well as descriptive information and population statistics on Swedish people more broadly, which are important for understanding identity development in context.

Despite being a lifelong developmental process, identity formation often comes to the foreground in adolescence due to biological and social changes (Erikson, 1968; Ferrer-Wreder \& Kroger, 2019; Kroger, 2007). The onset of puberty accompanied with cognitive, socio-emotional, and bodily changes

\footnotetext{
${ }^{2}$ The studies of this thesis used Arnett's $(2000,2012,2014)$ suggested age spans for different developmental phases, adolescence being proposed to occur largely between 10 and 18 years of age, emerging adulthood between 18 and 29, and young adulthood between 30 and the early forties.
} 
forces adolescents to reevaluate and question the continuity of their sense of self (Erikson, 1968). These individual and societal changes occur when adolescents start to seek identifications other than from their parents and when peer relationships start to become more important, which have been theorized to put greater emphasis on identity formation (Erikson, 1950, 1968, 1980). Adolescence is a time when individuals start to have both the latitude and ability to explore who they are as individuals and in relation to others (Erikson, 1950, 1968; Ferrer-Wreder \& Kroger, 2019; Kroger, 2007; Steinberg, 2014).

Emerging adulthood is notably a time when instability, possibilities, selffocus, feeling "in between," and identity exploration are particularly emphasized (Arnett, 2000, 2014). This instability relates to the fact that most emerging adults finish school during this time and need to sort out whether or not to continue with their studies, start working, or go travelling. In addition, this is a time when many move away from their parents, so living arrangements are often unstable as well. In this period, there are multiple choices in multiple areas that emerging adults need to explore and commit to, which is what Arnett $(2000,2014)$ was referring to when highlighting emerging adulthood as a time of possibilities. Also, the feeling of being in between is typical of this period of life, which lies between adolescence and adulthood, meaning that one feels like neither a child nor an adult (Arnett, 2000, 2014). Emerging adulthood is seen as a time of continued identity development marked by the exploration of future goals and directions in life (Arnett, 2000, 2006, 2014). However, this age of possibilities could arguably prolong the search for who one is and where one is heading in life (also referred to as identity moratorium), with possible negative psychological consequences, such as increased levels of anxiety and depression (Côté, 2019; Côté \& Allahar, 1994). It has been argued that, alongside rapid changes in today's society, experiences have become more individualized among young people, each of whom is responsible for his or her fate (Bauman, 2001; Côté, 2019; Côté \& Allahar, 1994; Furlong \& Cartmel, 2007; Giddens, 1991). In this individualized society, youth must reflexively alter their identities to adapt to their changing experiences, creating heightened feelings of risk and insecurity (Bauman, 2001; Beck, 1992; Giddens, 1991). Consequently, this heightened sense of risk may have a negative impact on multiple dimensions of individual identity formation (Côté, 2019; MottiStefanidi, 2015). Yet, the Nordic countries have been cited as cultural contexts that provide support that counteracts this negative trend (Côté, 2019). Sweden is especially highlighted by Côté (2019) as a cultural context minimizing this risk and insecurity through its policy-based practices (e.g., livelihood support, child allowance, financial aid for students, and parental benefit; see European Commission, 2019) promoting the finding of direction and purpose in life, regarded as important to healthy identity development (e.g., Côté, 2019; McAdams \& McLean, 2013). 
Moving into young adulthood, individuals often face new experiences and changing life circumstances that may challenge their sense of identity (Arnett, 2014; Kroger, 2015). For example, according to Statistics Sweden, many people start a family in their thirties (SCB, 2019c) after having established themselves in the labor market (SCB, 2019d), and during these years some have begun to advance in their careers. These new life experiences also need to be further integrated into the self-concept (Kroger, 2015; Syed \& McLean, 2015), meaning that identity also evolves with these new life experiences (McAdams \& Zapata-Gietl, 2015). In sum, young adulthood is a time in life when people start putting the decisions they made in their twenties, concerning, for example, occupation and family, into practice.

For many Swedes, as in many other affluent countries in the world, one's occupation is an important part of life (Inglehart et al., 2014) - not only from the perspective of making a living. Occupation has also been shown to be very important for who one is, one's identity (Frisén \& Bergh, 2006; Frisén \& Wängqvist, 2011). According to Statistics Sweden (SCB, 2019d), the employment rate increases from 54\% at ages 15-24 to 88\% at ages 25-34 years. The occupational context is clearly an issue that becomes more important during the progression toward adulthood, as most young people need to face issues of, for example, desired occupation, finding employment, and building a career (Arnett, 2014; Erikson, 1980; Kroger, 2007).

Another important area of life for young people in Sweden is that of romantic relationships (Frisén \& Bergh, 2006; Frisén \& Wängqvist, 2011; Wängqvist, Carlsson, van der Lee, \& Frisén, 2016). For many individuals around the world, romantic relationships begin to be important in adolescence, continuing on through emerging adulthood and into young adulthood (Collin, Welsh, \& Furman, 2009; Meier \& Allen, 2009). On their way toward adulthood, people become more intimate in their romantic relationships (Erikson, 1980; Kroger, 2007), and it has been suggested that the exploration of romantic relationships is a particularly important developmental task in emerging adulthood (Arnett, 2000). Many Swedes cohabit and start families without being married (Björnberg, 2001), as most young people in Sweden do not see marriage as important in itself, viewing it as primarily symbolic (Wängqvist et al., 2016). Parenthood can become a salient domain during young adulthood, given that many people choose to have children at this time (Erikson, 1980; Kroger, 2007). In Sweden, the mean age of entering parenthood is 29.3 years for women and 31.6 years for men (SCB, 2019c). Moreover, it has been demonstrated that becoming a parent is a strong norm in Sweden, although many emerging adults want to postpone having children (Frisén, Carlsson, \& Wängqvist, 2014). Although many Swedes do not become parents until reaching young adulthood, parenthood is an issue most people need to deal with and reflect on earlier due to societal expectations, as Sweden 
also has been described as having family-centered norms (Björnberg, 2001; Elvin-Nowak \& Thomsson, 2001; Sommestad, 1997). All in all, family has been shown to be one of the most important areas of life for many Swedes (Frisén et al., 2014; Inglehart et al., 2014).

Sweden is thus a country where both family and occupation are seen as very important (Frisén et al., 2014; Frisén \& Wängqvist, 2011; Inglehart et al., 2014). However, the importance of work/family priorities is not only a practical matter for many Swedes, but is important on an ideological level as well (e.g., Almqvist et al., 2011; Magnusson, 2008; Sommestad, 2008), making it especially interesting from an identity perspective. As occupation, romantic relationships, and parenthood are important identity-defining domains for many young people, the balance between them (i.e., work/family priorities) also likely constitutes a salient issue to be dealt with in everyday life.

\section{Theories of Identity}

What kind of mental models do you have in your head when you think about identity? A map with clear boundaries or the British coastal line of varying scale? In practice, both map types work.

Thomas Hylland Eriksen

Identity is an important aspect of life, and several theories and schools of thought address what forms and constitutes it. As the quotation above indicates (Hylland Eriksen, 2004, pp. 165-166), identity can be mapped in various ways. To understand the different dimensions of identity, such as aspects of identity process, content, and structure, as is striven for here, the multidimensional approach calls for adopting various theoretical perspectives in mapping identity. More specifically, this thesis draws on theoretical perspectives on identity drawn from developmental psychology, personality psychology, and social psychology, integrating the three identity theories described in the following section.

The most common identity theory used in developmental psychology, and the primary theory that informs this thesis, is Erikson's theory of identity development (Erikson, 1950, 1956, 1968, 1980). According to Erikson, 
identity formation is a process taking place at the intersection of the self and one's social context (Erikson, 1956, 1968). More specifically, in what is called the psychosocial perspective, Erikson $(1950,1968)$ postulated that identity has three dimensions-biological, psychological, and social-all of which influence the formation and development of identity. Based on this perspective, Erikson $(1950,1968)$ developed a model of psychosocial development comprising eight stages over the lifespan, each with important developmental tasks to be resolved in order to obtain psychological resources. This thesis focuses on the task of identity formation in the face of role confusion, which arises as a pronounced issue in adolescence and continues to be important throughout adulthood (Erikson, 1980; Kroger, 2007; Kroger, Martinussen, \& Marcia, 2010; Meeus, 2011). It is important to bear in mind that Erikson treated the developmental stages rather fluidly, as he seldom specified any particular age limits for the separate developmental phases (Syed $\&$ McLean, 2015). In addition, due to the prolonging of youth in today's society, what Erikson (1968) meant by adolescence would in today's terminology often encompass adolescence, emerging adulthood, and sometimes even young adulthood. The developmental task of identity formation versus role confusion formulated by Erikson (1968) is resolved by successfully integrating different aspects of the identity, with integrating the cognitive, affective, and behavioral aspects of identity being particularly important in adolescence (e.g., Berzonsky, 2011; Grotevant, 1987; Phinney, 1993). Integrating multiple areas of identity becomes especially important moving into emerging adulthood, as this is a time associated with role transitions and changing contexts (e.g., Arnett, 2000; Azmitia, Syed, \& Radmacher, 2008). In other words, identity development may be viewed as a lifelong process, or as Erikson himself put it: "Such a sense of identity, however, is never gained nor maintained once and for all. Like a 'good conscience,' it is constantly lost and regained" (Erikson, 1956, p. 74).

Although it is viewed as a lifelong process, Erikson $(1956,1968)$ suggested that the identity formation process really comes to the fore when a young person can no longer identify with his or her parents and thus needs to find others to identify with. Not being able to keep his or her childhood identifications, and needing to find his or her roles in society alongside the need to adapt to a changing body, alters the young person's perception of continuity, making the issue of identity formation especially important (Erikson, 1956, 1968). Furthermore, the new roles young adults face, with their multiple identifications (e.g., occupational identity, romantic relationship identity, and parental identity), may be in conflict with one another, possibly challenging identity integration and the sense of sameness (Erikson, 1956, 1968; Schachter, 2005a, 2013). This is crucial, because identity integration is 
seen as the most important developmental task in young adulthood, in order to achieve what Erikson referred to as identity synthesis.

Building on Erikson's work on identity formation, and representing another way to understand the various aspects of identity from the personality psychology perspective, is the theory of narrative identity (McAdams, 2001; McAdams \& McLean, 2013). Narrative identity theory posits that identity is formed through the construction of stories (McAdams; 1993, 2001; McAdams $\&$ McLean, 2013). According to McAdams (2011, 2015), the story might be the best way for people to organize their lives in time, in the past, present, and future, where knowing who one is involves telling a meaningful life story. In the narrated self, people attribute meaning to events to make sense of themselves and their lived experiences across time (McAdams, 1993). In other words, as identity formation takes place at the intersection of the self and one's contexts (Erikson, 1968), the stories one tells may be part of making sense of one's experiences, and at the same time reflect the cultural context in which one is situated (Galliher et al., 2017a; McLean et al., 2018; McLean, Syed, \& Shucard, 2016). The narrated identity, with roots in early childhood, begins to take form in late adolescence, as growing cognitive skill enables individuals to reflect on past, present, and future events (Habermas, Ehlert-Lerche, \& De Silveira, 2009; McAdams, 1993, 2001). These life stories are internalized and evolve over the lifespan, providing individuals with temporal continuity, unity, and a sense of purpose (McAdams, 1993; McAdams \& McLean, 2013). The narrative identity is viewed as an important part of personality development and can be understood as "a further development of the person as a social actor and a motivated agent" (McAdams, 2015, p. 7). McAdams (2015) described narrative identity as a third layer of personality on top of dispositional traits, and goals and values.

One of the most important identity theories from a social psychology perspective is social identity theory (Tajfel \& Turner, 1979, 1986). Primarily, social identity theory provides a means of understanding intergroup behavior and is considered the first theory to conceptualize identity at a group level (Spears, 2011). Social identity theory may be understood as addressing the part of people's identities derived from the social group to which they consider themselves to belong (Tajfel \& Turner, 1979, 1986). According to Tajfel and Turner $(1979,1986)$, it is not enough for others to consider a person part of a group to create a sense of social identity; instead, group membership needs to be internalized within the person's sense of self. Social identity theory further posits that people favorably compare the groups to which they belong (i.e., ingroups) with other relevant groups (i.e., out-groups) to create value and positively distinguish their group from others (Tajfel \& Turner, 1979, 1986). Ultimately, this quest for distinctiveness, as Spears (2011) put it, conveys information about who we are. Furthermore, the integration of an individual's 
sense of self with the social milieu and the group with which he or she identifies intensifies during adolescence (Cross \& Cross, 2008; Ferrer-Wreder \& Kroger, 2019). Lastly, Spears (2011) also emphasized that the original idea of social identity was not that it should be seen as more important than other forms of identity, but that it should be seen as an aspect of identity that may be more or less salient depending on the context.

\section{Integrating Theories and Applying a Multidimensional Approach}

At first glance, some of the various theories of identity may seem to contradict one another, when it is instead a matter of seeing identity from different perspectives stressing different dimensions of identity. For example, a developmental psychologist may tend to zoom in on the internal psychological processes of identity, whereas a social psychologist may zoom out, seeing the external social processes of identity. Furthermore, whereas research into Erikson's identity theory and social identity theory has tended to focus on identity processes, narrative identity research, although also considering processes, concentrates on the in-depth content of identity - the stories we construct about ourselves and our surroundings. None of these perspectives is necessarily better than another; they are simply different ways of understanding and mapping identity. Although there has been an increase in studies adopting an integrated approach (see, Galliher et al., 2017a; Galliher, Rivas-Drake, \& Dubow, 2017b; van Doeselaar, Becht, Klimstra, \& Meeus, 2018), there are still areas where research is scarce. Bringing identity concepts such as social identity theory from social psychology into the Eriksonian field of identity arguably fosters several important insights into the field of identity (Côté, 2015; Crocetti, Prati, \& Rubini, 2018; Thorne, 2004). Doing so would bring out the social aspect of Erikson's psychosocial approach, which has been somewhat neglected in prior research (Rogers, 2018; Syed \& McLean, 2015). Applying an integrated theoretical approach to identity is likely to benefit our understanding of the different dimensions and complexity of the concept of identity (Côté, 2015; Ferrer-Wreder \& Kroger, 2019; Kroger \& Marcia, 2011; Pasupathi, 2014; Schachter, 2013; Schwartz, Luyckx, \& Crocetti, 2015; Syed \& McLean, 2015; van Doeselaar et al., 2018).

Moreover, as emphasized in Figure 2, not only might identity be studied both as a whole and across different domains, but different dimensions of identity may also be studied (see, Berzonsky, Macek, \& Nurmi, 2003; Kroger, 1997, for noteworthy work using a multidimensional approach to identity). One dimension, depicted in Figure 2 as cogwheels, comprises identity 
processes, which include the processes of identity exploration and commitment. Another dimension is identity content, shown by the text in the figure, for example, what actually constitutes occupational identity or the content of which ethnic identity is made. A third dimension is identity structure, illustrated as the fragmented parts of Figure 2, where the sometimes conflicting, multiple identifications need to be configured into a workable whole, in what is described by Erikson $(1956,1968)$ as identity synthesis. Last, as shown in Figure 2, all these dimensions are highly influenced by the cultural context in which the individual is situated (Azmitia, 2015; Erikson, 1968; Fivush \& Zaman, 2015; Galliher et al., 2017a; Hammack, 2008; McLean et al., 2018).

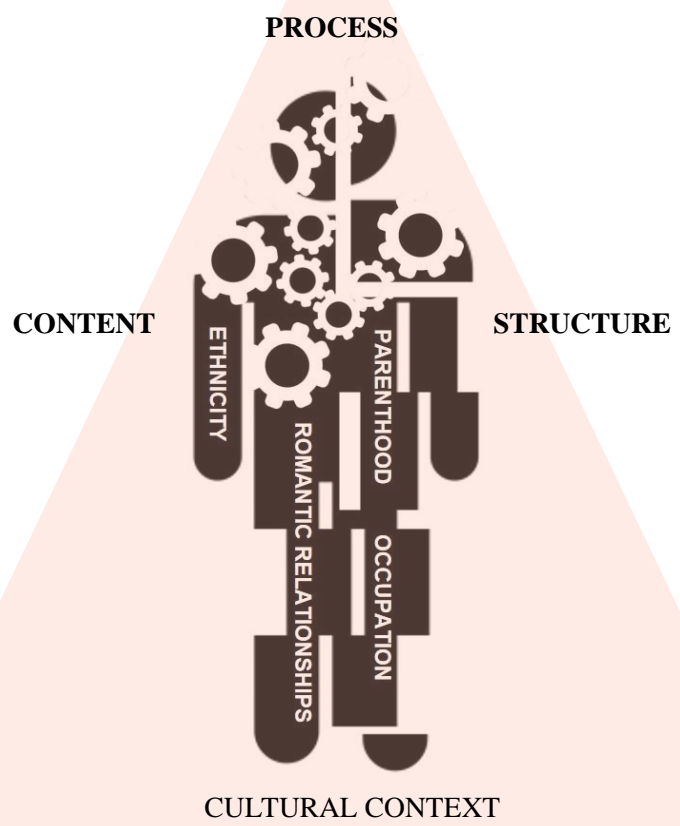

Figure 2. Visualization of the different dimensions of identity. 
Most previous research on identity from a developmental perspective has focused on identity processes, such as the processes of exploring identitydefining issues and committing to the choices made (see, Marcia, 1966; Crocetti \& Meeus, 2015). In the last ten years, increased attention has been paid to the content of identity, that is, the substance that actually constitutes identity, using a narrative approach (see, Adler et al., 2017; Galliher et al., 2017a), including understanding identity both in terms of single domains (e.g., occupation, religion, parenthood, and ethnicity/culture) and as a global construct. However, research on how identity is structured, that is, how individuals manage and negotiate their multiple identifications and structure them into a workable whole in different types of identity configurations, is still in its infancy.

The dimensions of identity process, content, and structure are intertwined and difficult to separate, as they are interdependent. However, to better understand identity we need to look at these dimensions separately when studying them. For example, it has been emphasized that studying narrative content provides a better understanding of identity processes, giving insight into what constitutes identity (Galliher et al., 2017a; McLean \& Syed, 2015). Similarly, studying identity structure may help us understand how both process and content are interdependent and function together to form a workable identity.

In this thesis, I therefore adopt an integrated theoretical approach, as this is necessary in order to capture different dimensions of identity in context. More specifically, identity is investigated mainly from an Eriksonian standpoint, with other identity perspectives being brought in to understand aspects of identity process, content, and structure. Study I examines aspects of identity process by combining Erikson's identity theory with social identity theory. Study II explores aspects of identity content from a theoretical perspective stemming from both narrative identity theory and social identity theory. Last, Study III uses both Erikson's identity theory and narrative identity theory to capture the structure of identity. In this way, this thesis adopts a theoretically integrated approach to understanding multidimensional aspects of identity. In the following sections, the dimensions of identity process, identity content, and identity structure will be described to foster a multidimensional understanding of identity. 


\section{Understanding Identity Process}

An existing individual is constantly in process of becoming.

Søren Kierkegaard

As Kierkegaard (1944, p. 79) emphasized in the above quotation, identity development entails lifelong processes (Erikson, 1980; Ferrer-Wreder \& Kroger, 2019; Kroger, 2007; Kroger, Martinussen, \& Marcia, 2010; Meeus, 2011; Whitbourne, Sneed \& Skultety, 2002). Identity processes have primarily been the object of study in developmental psychology (e.g., Galliher et al., 2017b; Marcia, 1966; Meeus, 2011; van Doeselaar et al., 2018; Whitbourne et al., 2002), conceptualizing Erikson's writings on identity as emphasizing the processes of exploration and commitment. Although other identity-defining processes such as autobiographical reasoning from a narrative identity perspective (e.g., Habermas \& Köber, 2015; Fivush, Habermas, Waters, \& Zaman, 2011; McLean \& Fournier, 2008) and the process of selfcategorization from a social identity perspective (e.g., Hogg, 2000; Hornsey, 2008; Turner \& Reynolds, 2012) should also be acknowledged, this thesis, more specifically Study I, focuses on understanding the processes of exploration and commitment and their relationships to the process of social comparison in young adulthood, a period of life that has been largely neglected in prior research.

\section{Identity Status Model}

One of the most commonly used conceptualizations of Erikson's work is called the identity status model (see Figure 3), formulated by Marcia (1966, 1993). This model is intended to capture the identity processes of exploration and commitment. Identity exploration may be understood as the process by which the individual actively explores identity-defining alternatives with the aim of reaching decisions (Kroger \& Marcia, 2011; Marcia, 1966). Identity commitment, on the other hand, concerns making decisions regarding identitydefining issues (Kroger \& Marcia, 2011; Marcia, 1966). From these processes of exploration and commitment, four identity-formation positions, or identity 
statuses as they are called, were formulated: identity achievement, identity foreclosure, moratorium, and identity diffusion.

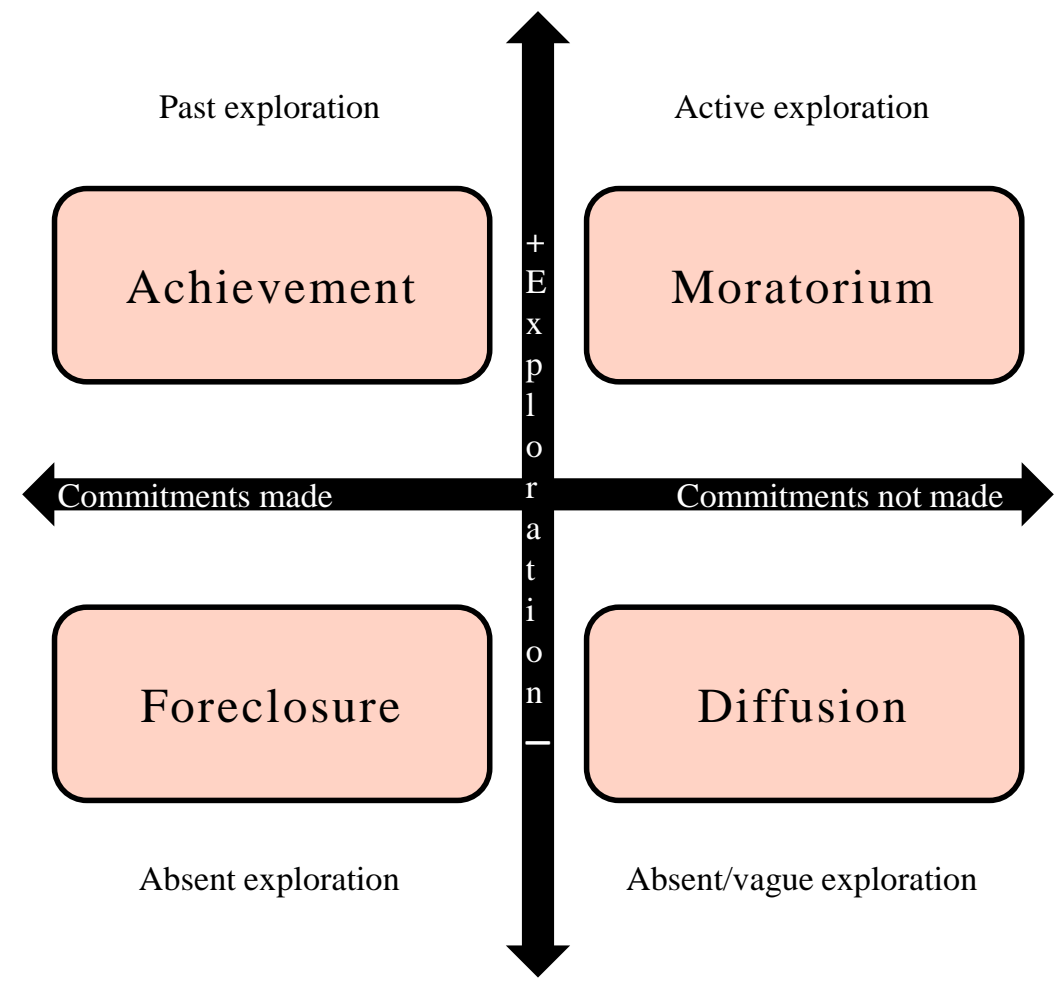

Figure 3. Schematic of the identity status model.

In brief, people in identity achievement are characterized as having made identity-defining commitments after a time of exploration (Kroger \& Marcia, 2011; Marcia, Waterman, Matteson, Archer, \& Orlofsky, 1993). These people have been described as difficult to persuade yet flexible in the decisions they have made concerning identity-related issues (Kroger \& Marcia, 2011). Also, a pronounced feature of people in identity achievement is a high level of moral reasoning (Jespersen, Kroger, \& Martinussen, 2013; Marcia et al., 1993) and an internal locus of control (Lillevoll, Kroger, \& Martinussen, 2013; Marcia et al., 1993). People in foreclosure characteristically have made commitments without exploring possible alternative values or goals (Marcia et al., 1993). People in foreclosure are therefore often considered as having an ascribed rather than a constructed identity (Kroger, 2015). Generally, people in 
foreclosure are not as flexible as are people in identity achievement; instead, they hold on to their commitments and are less autonomous (Kroger \& Marcia, 2011; Marcia et al., 1993). In addition, people in identity foreclosure have been described as having an external locus of control (Lillevoll, Kroger, \& Martinussen, 2013; Marcia et al., 1993) as well as reporting more authoritarianism than do people with the other identity statuses (Marcia et al., 1993; Ryeng, Kroger, \& Martinussen, 2013). Moratorium is described as the identity position of active exploration without making any commitments (Marcia et al., 1993). People in moratorium accordingly experiment with various alternative roles, values, and goals with the aim of making identitydefining commitments (Kroger \& Marcia, 2011). People in moratorium are in the midst of what Erikson (1968) called an identity crisis, although this crisis may be more or less intense (e.g., Arnett, 1999). In addition, people in moratorium are characterized by being very engaged, sometimes intensely so, in their exploration of identity-defining alternatives (Marcia et al., 1993). The final identity position, identity diffusion, was originally described by Marcia (1966) as characterizing those who have not explored nor made any commitments. Subsequent research has found that identity diffusion varies in style and that people in identity diffusion may engage in what has been described as a weak form of exploration (Kroger \& Marcia, 2011). Characteristically, people in identity diffusion often lack an internal sense of self-definition and any clear direction in life (Kroger \& Marcia, 2011). People in identity diffusion have been found to be either carefree individuals going with the flow (e.g., Schwartz et al., 2011) or more troubled individuals without a clear sense of purpose (Kroger \& Marcia, 2011).

As most research on identity status has focused on identity development in adolescence and emerging adulthood, there is a lack of research on identity status in young adulthood (Kroger, 2015). The few studies conducted among people in their thirties have found that the proportion of people in identity diffusion and moratorium seems to decrease when approaching young adulthood, and that many young adults tend to have made identity commitments after a time of identity exploration, thus being identity achieved (see Arneaud, Alea, \& Espinet, 2016; Kroger et al., 2010; Meeus, 2011; Shirai, Nakamura, \& Katsuma, 2016). Furthermore, research into gender differences in identity status among young adults is even scarcer (see Kroger, 1997; Kroger et al., 2010; Meeus, 2011, for reviews). However, some studies, not specifically on people in their thirties, have shown that women seem to progress toward identity achievement before men do (Fadjukoff, Pulkkinen, \& Kokko, 2016; Kroger, 1997; Meeus, Van De Schoot, Keijsers, Schwartz, \& Branje, 2010), while still others have suggested that the pattern of identity development is similar in both genders (Archer \& Waterman, 1988; Waterman, 1999). When it comes to young adults, no gender differences have been found 
in the distribution of global identity status (Pulkkinen \& Kokko, 2000) or, more specifically, in the degrees of commitment and exploration (Shirai et al., 2016). Still, not only may identity status vary between genders across cultural contexts and ages, but there may also be gender differences across different life areas, also known as identity domains (Archer, 1989, 1985; Fadjukoff, Pulkkinen, \& Kokko, 2005; Meeus \& Deković, 1995; Meeus et al., 2010; Waterman, 1999).

\section{Social Comparison}

Another process important to identity development, and the focus of Study I, is that of social comparison. The link between social comparison and Eriksonian identity theory is not tenuous, given that social comparison concerns "our quest to know ourselves, about the search for self-relevant information and how people gain self-knowledge and discover reality about themselves" (Mettee \& Smith, 1977, pp. 69-70). In fact, Erikson (1968) wrote about the importance of social comparison for identity formation: "The counterplayers of the 'selves' are the 'others,' with which the 'I' compares the 'selves' continually - for better and for worse" (Erikson, 1968, p. 217). As Erikson's (1968) idea was that identity was created through interaction between the inner and outer worlds, one such interaction is likely the process of comparing oneself with other people.

Originally formulated by Festinger (1954), social comparison theory aims to explain how and why people compare themselves with others. Social comparison may also be viewed as a process closely related to identity formation. Festinger (1954) claimed that the drive to compare oneself to similar others is inherent in all humans, as a means to evaluate where one stands in life regarding opinions and abilities in various areas of life, the more important the area, the stronger the need for social comparison. Postulated as essential to human social life, social comparison has been found to be associated with multiple factors related to various self-concepts, such as neuroticism, openness, narcissism, low self-esteem, and uncertainty about the self (e.g., Buunk \& Gibbons, 2007). Moreover, according to social identity theory, it is partly through social comparison that a sense of the self as an individual is formed (Hogg, 2000; Spears, 2012; Tajfel \& Turner, 1979, 1986).

Social comparison has primarily been studied in the social psychological and sociocultural research fields (see, Buunk \& Gibbons, 2007; Gerber, Wheeler, \& Suls, 2018; Lunde \& Gyberg, 2016), where, as previously mentioned, it is considered an important part of social identity (e.g., Spears, 2011; Tajfel \& Turner, 1979, 1986; Turner, 1975). Although Erikson wrote about the importance of social comparison for identity formation, research 
linking social comparison and identity status is scarce. Even though social comparison has been emphasized as theoretically important in relation to identity status (Crocetti et al., 2018; Meeus et al., 1997), no studies have specifically investigated this potential relationship. To address this lack, Study I investigates identity process by studying the relationship between social comparison and identity status globally and across domains among women and men in young adulthood.

\section{Understanding Identity Content}

I have parents and occupation. I have family, children, interests. My self must be in the combination of all this.

Sven-Eric Liedman

In the last decade, increased attention has been paid to the content of identity, that is, the constituent elements that is identity (Galliher et al., 2017a; McLean, Syed, Yoder, \& Greenhoot, 2016; Syed \& McLean, 2015). To understand what identity content is, Galliher and colleagues (2017a) have developed an integrated developmental model with four interrelated levels of analysis to capture identity content. The levels of the model range from distal to proximal in order to understand the content that constitutes identity. At the broadest level of content lie the cultural and historical contexts in which the individual is situated. Culture influences who we are by means of the norms and expectations it upholds as well as the limitations and constraints prescribed (e.g., Galliher et al., 2017a; McLean et al., 2017; McLean \& Syed, 2015). At the second level of identity content are social roles, that is, how we relate to important others (Galliher et al., 2017a). Our relational selves are important for who we are and are integrated into our sense of self. At the third level of identity content are identity domains, that is, the different areas of life important to who we are. Last, at the most proximal fourth level of identity content are everyday experiences, including our thoughts, feelings, and actions embedded in our identities. In this thesis, Study I focuses on identity processes in different identity domains, Study II on the lowest level of identity content, that is, everyday experiences, in the identity domain of ethnic identity, and Study III on how identity content is negotiated within potentially conflicting 
identity domains. The following section describes the concept of identity domains.

\section{Identity Domains}

Identity development takes place across multiple identity-defining domains, also referred to as content domains, each with its own identifications, as emphasized in the above quotation from Liedman (1999, p. 65). Several advantages of studying identity domains have been highlighted (e.g., Kroger, 2003; Goossens, 2001; Grotevant, 1987; Schwartz, 2001). For example, by studying identity domains separately, differences in processes, such as those previously mentioned, may be captured that otherwise might not be obvious when studying global identity, such as different developmental trajectories for women and men across different identity domains (Archer, 1989; Fadjukoff et al., 2005; Galliher et al., 2017a; Kroger, 1997). Erikson (1968) theorized that the occupational and ideological domains were the most important ones, whereas Marcia (1966) separated the ideological domain into the political and religious domains. Later, Grotevant, Thorbecke, and Meyer (1982) added the interpersonal domains of friendship, dating, and sex roles. The salience of different identity domains for individuals generally depends on what is important for the particular age group and cultural context involved (Marcia, 2001; Marcia et al., 1993). Thus, the identity domains that are salient for individuals do not need to reflect what they already have, although having, for example, a family may make the exploration of and commitment to identity issues related to family more relevant to some people. Rather, the norms, values, and expectations of the cultural context in which the individual is situated, often referred to as master narratives, are important aspects of the domains important for people's identities (see Galliher et al., 2017a; Hammack, 2008; McLean, Boggs, Haraldsson, Lowe, Fordham, Byers, \& Syed, 2019; McLean et al., 2017; McLean \& Syed, 2015). In addition, multiple studies have shown that deviating from cultural norms of what is expected induces further identity development processes and identity awareness, as individuals deviating from master narratives may need to develop an alternative narrative in order to feel belongingness and a positive sense of self, making the domain even more central to people's identities (Galliher et al., 2017a; McLean et al., 2017, 2019; McLean \& Syed, 2015).

In Sweden, previous studies have demonstrated that important life domains are occupation, romantic relationships, parenthood, work/family priorities (Bergh \& Erling, 2005; Carlsson, Wängqvist, \& Frisén, 2015; Fagerberg \& Kihlgren, 2001; Frisén et al., 2014; Frisén \& Wängqvist, 2011; Wängqvist et al., 2016), and, more recently, the body (Kling, Wängqvist, \& Frisén, 2018; 
Nelson, Kling, Wängqvist, Frisén, \& Syed, 2018; Wängqvist \& Frisén, 2013). However, only a few of these studies have looked more closely at the actual identity content of some of these domains (i.e., Frisén et al., 2014; Kling et al., 2018; Wängqvist et al., 2016). One important aspect of identity content that has been largely neglected is in the domain of ethnicity, more specifically, ethnic identity (Phinney, 1990; Syed \& Fish, 2018), which is also likely to be relevant in a Swedish context, especially for those whose ethnicities do not correspond to the normative expectations of "Swedishness". As the content of ethnic identity is the focus of Study II, in the following I describe this identitydefining domain more thoroughly.

\section{Ethnic Identity}

Building on both Erikson's theory of identity and social identity theory, the concept of ethnic identity has been suggested to be "based on a universal need to define oneself in one's context" (Phinney, 2000, p. 30). Ethnic identity may be described as the degree to which individuals identify themselves in relation to beliefs, attitudes, and behaviors associated with their ethnic group or groups (Phinney \& Ong, 2007; Umaña-Taylor et al., 2014; Verkuyten, 2018). The formation of ethnic identity may be explained as people's exploration of their own ethnicity, of the meaning, expectations, and knowledge that ethnicity brings to their understanding of themselves (Phinney, 1990; Phinney \& Ong, 2007). Furthermore, ethnic identity may become especially pronounced in young people with immigrant backgrounds, as they are more likely to experience contrasting beliefs and attitudes from different cultures that they need to integrate into their self-concept (e.g., Phinney, Ong, \& Madden, 2000; Verkuyten, 2018). Although we all have one or several ethnicities, most research on ethnic identity has concentrated on ethnic minorities (see RivasDrake et al., 2014a; Rivas-Drake, Syed, Umaña-Taylor, Markstrom, French, Schwartz, \& Lee, 2014b; Schwartz, Syed, Yip, Knight, Umaña-Taylor, RivasDrake, \& Lee, 2014; Smith \& Silva, 2011, Umaña-Taylor et al., 2014, for reviews).

From a developmental perspective, adolescence is a period when an understanding of shared (or unshared) experiences of ethnic identity become especially pronounced (Ferrer-Wreder \& Kroger, 2019; Umaña-Taylor et al., 2014). Moving into emerging adulthood and later young adulthood, ethnic identity content may become more complex: it has to be integrated into other parts of life as one's contexts often change and one's social setting expands (Syed, 2010; Umaña-Taylor et al., 2014). Establishing a sense of ethnic identity is thus an important developmental task during adolescence and emerging adulthood (Ferrer-Wreder \& Kroger, 2019; Phinney, 2006; Umaña- 
Taylor et al., 2014). Moreover, possessing an integrated ethnic identity, that is, feeling part of both one's ethnic group and of larger society, has been linked to several positive outcomes, such as positive psychological functioning and well-being (Kiang, Yip, \& Fuligni, 2008; Quintana, 2007; Rivas-Drake et al., 2014a, 2014b; Smith \& Silva, 2011; St. Louis \& Liem, 2005; Syed \& Juang, 2014; Wissink, Deković, Yağmur, Stams, \& de Haan, 2008).

Although a vast amount of international research has explored ethnic identity development (see Rivas-Drake et al., 2014a, 2014b; Smith \& Silva, 2011; Umaña-Taylor et al., 2014, for reviews), research on the specific content of ethnic identity is still scarce. Only two psychological studies have investigated the everyday experiences of ethnic identity (i.e., Syed \& Azmitia, 2008, 2010). The everyday experiences examined in these studies, which included ethnically diverse American college students, mainly concerned prejudice and discrimination, feelings of being connected to culture, awareness of difference in terms of ethnicity, behavior, or cultural practices, and awareness of underrepresentation, which involved realizing that the surrounding people belonged to an ethnic group other than one's own.

Although ethnic identity is formed through lived experiences in a broader cultural context, experiences that are integrated into the self-concept (Phinney, 2000; Phinney \& Ong, 2007; Syed, 2015; Umaña-Taylor et al., 2014; Worrell, 2015), we know very little about the development of ethnic identity in the Swedish cultural context (Ferrer-Wreder et al., 2012). However, a few studies within the International Comparative Study of Ethnocultural Youth (ICSEY; Berry et al., 2006) included measures of ethnic identity among immigrant youth. Comparing 13 countries around the world (including Sweden), these studies from the ICSEY focused on theories of acculturation, that is, how individuals balance multiple cultural orientations (Berry et al., 2006). These studies demonstrated that ethnic identity was related to more positive outcomes, such as psychological adaptation, among immigrant youth in Sweden than in some of the other studied countries (e.g., Vedder \& Virta, 2005; Virta, Sam, \& Westin, 2004). However, we still know little about the content of ethnic identity in Sweden.

Few studies have examined the content of ethnic identity in Sweden. Although not specifically addressing the everyday experiences of ethnic identity, the combined results of several studies indicate that people with immigrant backgrounds struggle to fit in and adapt to Swedish society (Johansson \& Olofsson, 2011; Scuzzarello \& Carlson, 2018; Wikström, 2007; Wigg, 2008). Wikström (2007) interviewed parents and young adults from seven Iranian families in Sweden, identifying three types of experiences connected to their ethnic identity: experiences of distancing from the Iranian heritage, experiences of being both Swedish and Iranian, and experiences of being neither. In a study by Wigg (2008), interviews with eight emerging 
adults, all but one from the former Yugoslavia, indicated that experiences of being an immigrant in Sweden included elements of both being part of a community and being an outsider. The main themes identified in these interviews were having an outsider identity and having a torn identity. In a case study of four young individuals with immigrant backgrounds, Johansson and Olofsson (2011) found that the participants tried to adapt to expectations of "Swedishness." Furthermore, Scuzzarello and Carlson (2018) conducted focus group interviews and individual interviews with emerging adult Somalis in Sweden and the United Kingdom. Their findings indicated differences between the Swedish and British samples in how ethnic identify was constructed and negotiated, with the Somalis in the Swedish sample expressing difficulties identifying with majority society due to clear boundaries between being a "Swede" and being an "immigrant." This resulted in competition with native Swedes to forge a positive identity.

These studies, which suggest areas for future research, are all, except the study by Scuzzarello and Carlson (2018), based on sociological theories of identity. Also, these studies use small homogenous samples and do not take differences in experience due to age or self-identified ethnicity into account. There is thus a need to further explore these findings from a psychological identity perspective, investigating ethnicity-related everyday experiences among young people in Sweden and how these experiences might vary by age and among individuals with different ethnic backgrounds. This is the aim of Study II.

\section{Understanding Identity Structure}

I am not one and simple, but complex and many... Underneath, and, at the moment when I am most disparate, I am also integrated.

Virginia Woolf

Erikson (1956, 1968) emphasized a "final" identity, taking form when all important identifications become integrated into a whole, as emphasized in the above quotation (Woolf, 1931, pp. 76-77). Erikson stated that identity "includes all significant identifications, but it also alters them in order to make a unique and reasonably coherent whole of them" (Erikson, 1968, p. 161). This reasonably coherent identity is also referred to by Erikson $(1956,1968)$ as 
identity synthesis, and achieving this is one of the most important developmental tasks in young adulthood. In other words, identity synthesis is what comes of identity formation as childhood identifications are internalized to a state in which the sense of self is the same in the past, present, and future, endowed with a sense of sameness and continuity. As previously mentioned, the vast majority of prior research on identity has focused on identity processes and, more recently, on identity content, largely neglecting how individuals structure their identities. Research on how identity is structured, for example, on how individuals manage and negotiate their multiple identifications across identity domains and structure them into a workable whole in various identity configurations, is still in its infancy. In the following section, identity configurations are further described, as this is the dimension investigated in Study III.

\section{Identity Configurations}

Identity configurations are one way of capturing and understanding the actual structure of how individuals negotiate and integrate their sometimes conflicting multiple identifications across domains, consisting of values, beliefs, and experiences, into their broader sense of self (Schachter, 2004, 2013). To create what Erikson referred to as a reasonably coherent whole, the individual must, as previously mentioned, organize and structure his or her multiple identifications (Erikson, 1956, 1968; Schachter, 2004, 2013). Although such structuring is an essential part of identity formation, few studies examine how people structure their identities into different identity configurations (i.e., Dahl \& Galliher, 2012; Hammack, 2010; Hammack, Thompson, \& Pilecki, 2009; Schachter, 2004, 2005; Syed, 2010), and most of these studies have focused on drawing theoretical conclusions in understanding identity structure and investigating minority identities.

Schachter (2004) was the first to conceptualize Erikson's writings on identity configuration by investigating how 30 Jewish Modern Orthodox young men negotiated conflicting sexual and religious identities to form different types of workable configurations. He found that some men tried to suppress or reject one identification over another, while others tried to keep both identifications. Schachter (2005a) went on to deepen our knowledge of identity configurations through a case study of a young Jewish Modern Orthodox man's developmental experiences of science and religion. Schachter $(2004,2005 a)$ concluded that identity development should be viewed as the configuration of identity elements that are negotiated and co-constructed within a given context in multiple ways depending on the cultural context, content, and developmental specifics. Building on this work, two studies of 
sexual minority youth (i.e., Dahl \& Galliher, 2012; Hammack et al., 2009) found different ways of creating workable identity configurations, highlighting the matter of context, as the societal discourse did not always match the participants' desires and behaviors. Two studies with a longitudinal approach have been conducted (i.e., Hammack, 2010; Syed, 2010), illustrating how identity configurations evolved over time as young people faced new experiences, which sometimes made them restructure their identities.

In young adulthood, most individuals face new life experiences, such as getting established in the labor market and starting a family, and these new roles need to be integrated into their existing sense of identity (Kroger, 2015; Syed \& McLean, 2016). However, these identifications may conflict with one another, which may challenge individuals' identity integration and sense of sameness (Erikson, 1956, 1968; Schachter, 2004, 2013). This type of role immersion is not limited to people who have a family and an occupation; family and work constitute issues that most young adults must relate to in one way or another, due to societal norms and expectations (e.g., Arnett, 2006, 2015; Kroger, 2007, 2015). Erikson (1968) specifically highlighted this type of role immersion between work and family in his writings on identity formation and womanhood, where he stated (p. 291):

As an individual person, finally, she utilizes her (biologically given) inclinations and her (technologically and politically given) opportunities to make the decisions that would seem to render her life most continuous and meaningful without failing the tasks of motherhood and citizenship. The question is how these three areas of life reach into each other-certainly never without conflict and tension and yet with some continuity of purpose.

In many societies today, in contrast to the historical context in which Erikson was situated, the negotiations between occupational and family identifications are identity issues not exclusively facing women. Configuring occupational and family identities may be particularly interesting in relation to the Swedish cultural context, as both occupation and family have been shown to be highly important for Swedish women and men (Inglehart et al., 2014), related not only to practical issues in everyday life, as people are expected both to have a career and care for their families (e.g., Almqvist et al., 2011; Duvander, 2014; Haas \& Hwang, 2000; Johansson \& Klinth, 2008; Sommestad, 1997), but also to their identities (e.g., Frisén et al., 2014; Frisén \& Wängqvist, 2011). Yet Erikson's question regarding how these areas interpenetrate, how they are structured into different types of identity configurations, remains unanswered. 
Understanding identity configurations is important in order to get a more multidimensional understanding of the complexity that identity entails, in terms of both how identity is formed in regard to process, content, and structure, and how it is affected by cultural context (Galliher et al., 2017a; Hammack, 2008; Schachter, 2004, 2005a, 2005b). However, although all the abovementioned studies add to research illustrating how identity configurations may provide meaning and coherence to individuals' sense of self and their experiences when facing conflicting discourses, few of them enable broader generalizations to a wider population. In addition, although some studies have measured conflict related to integrating multiple identifications (e.g., Dahl \& Galliher, 2009; Dehlin, Galliher, Bradshaw, \& Crowell, 2015), no study has measured the degree of conflict across different types of identity configurations. Also, no study has investigated how different identity configurations, with their potentially different degrees of conflict, are related to measures of psychological well-being. Study III responded to this research gap by investigating how young adult women and men in Sweden structure their work and family identities into different types of identity configurations, and the potential differences in degree of conflict and life satisfaction related to different identity configurations.

\section{Challenges in Understanding Identity Process, Content, and Structure}

Despite the advances in our knowledge of identity development, as previously mentioned, important questions remain to be answered. The following summarizes existing research gaps in our understanding of identity process, content, and structure in context.

Although research on identity development has concentrated on identity process such as the processes of exploration and commitment to identitydefining issues, certain aspects of these processes remain to be explored. One such aspect is identity status in young adulthood, a period in life largely neglected in prior research (see Kroger et al., 2010; Meeus, 2011, for reviews). Even scarcer is research on gender similarities and differences in identity status among people in their thirties (see Pulkkinen \& Kokko, 2000; Shirai et al., 2016, for noteworthy exceptions). Furthermore, most studies conducted among young adult women and men have investigated identity status globally without investigating the identity processes of exploration and commitment across important identity domains, even though it has been suggested that identity 
status may vary between women and men across domains, contexts, and points in life (e.g., Archer, 1989; Fadjukoff et al., 2005; Kroger, 1997; Meeus et al., 2010; Waterman, 1999). In addition, no prior study has specifically investigated how the identity processes of identity exploration and commitment are related to the process of social comparison, although this link has been theoretically implied (Erikson, 1968; Crocetti et al., 2018; Meeus et al., 1997).

Although research on identity content, that is, the lived everyday experiences that constitute identity, has increased over the latest decade, there are still identity domains that need to be further explored (Galliher et al., 2017a; McLean et al., 2016; Phinney, 2003; Syed \& McLean, 2015). One such aspect of identity content is in the domain of ethnicity, more specifically, ethnic identity (Phinney, 1990; Syed \& Fish, 2018). Furthermore, although ethnic identity development is arguably highly dependent on cultural context (e.g., Dimitrova, 2014; Syed, 2015; Worrell, 2015), research on ethnic identity content outside the United States is generally lacking (Chao \& Otsuki-Clutter, 2011; Syed \& Mitchell, 2013; Way \& Rogers, 2015). Research on ethnic identity content in a Swedish context is even scarcer, especially research from a psychological point of view and using relatively large samples including individuals with diverse ethnic backgrounds.

In addition, identity structure is the least studied identity dimension, especially regarding identity configurations and how individuals negotiate and integrate their sometimes conflicting multiple identifications across domains into a broader sense of self, about which only a handful studies have been conducted (i.e., Dahl \& Galliher, 2012; Hammack, 2010; Hammack et al., 2009; Schachter, 2004, 2005; Syed, 2010). As prior research has mostly focused on limited domains related to minority identity with limited sample sizes, there is a need for research on other culturally important identity domains using larger samples drawn from more general populations in order to increase our ability to generalize and draw broader conclusions. We also do not know whether there may be differences in identity configurations between women and men. In addition, although the matter is highly relevant to understanding how individuals negotiate their conflicting multiple identifications (Erikson, 1956, 1968; Schachter, 2004), no study has investigated how internal conflict may vary between different identity configurations. Likewise, no empirical research has considered how different ways of structuring one's identity in different identity configurations are related to aspects of well-being.

Last, although it is highly important for aspects related to identity process, content, and structure, identity research taking the cultural context into account is still limited (e.g., Galliher et al., 2017a, 2017b; McLean et al., 2018; Schachter, 2005). Even more so, identity research taking an integrated 
approach within the cultural context of Sweden, a country that differs notably from other countries (e.g., WVS, 2015), is even scarcer.

\section{General Aim}

The general aim of this thesis is to obtain a multidimensional understanding of identity in context by using an integrated theoretical approach to investigating understudied aspects of identity process, content, and structure in context. More specifically, as can be seen in Figure 4 (on the following page), Study I examines aspects of identity process among young adults by investigating:

- gender similarities and differences in identity status both globally and across important identity-defining domains

- the relationship between identity status and social comparison

Study II examines aspects of identity content among adolescents and emerging adults by investigating:

- ethnicity-related experiences among adolescents and emerging adults using a narrative approach

- differences in these experiences due to immigrant status, selfidentified ethnicity, and age group

Last, Study III examines aspects of identity structure among young adults by investigating:

- types of configurations of occupational and family identities among young adults

- gender similarities and differences in identity configurations

- differences in degree of conflict and life satisfaction across identity configurations 


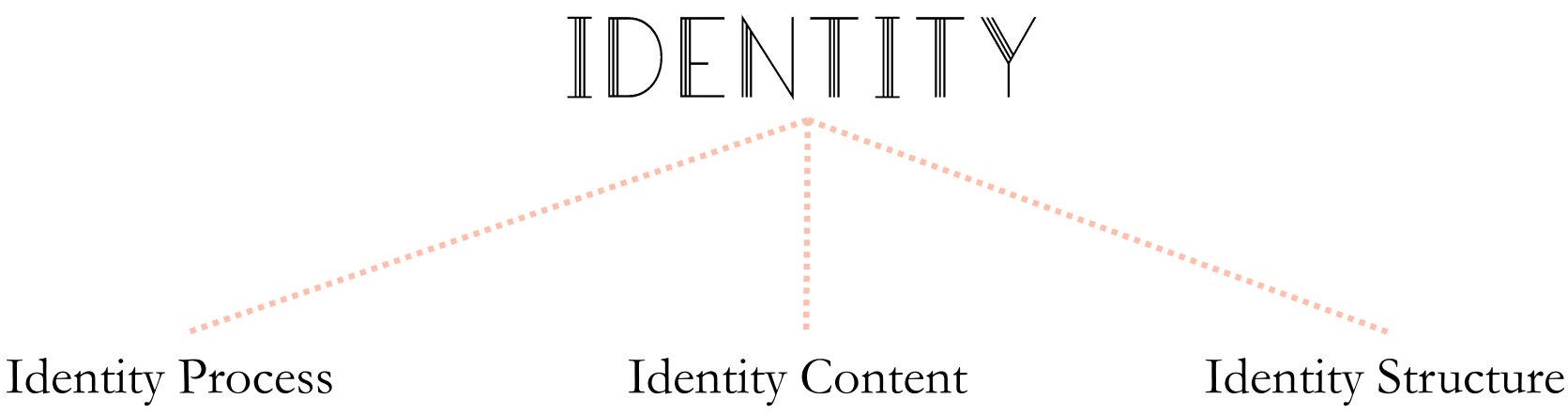

\section{STUDY I}

Gyberg, F., \& Frisén, A. (2017). Identity status, gender, and social comparison among young adults. Identity, 17, 239-252.

\section{STUDY II}

Gyberg, F., Frisén, A., Syed, M., Wängqvist, M., \& Svensson, Y. (2018). "Another kind of Swede": Swedish youth's ethnic identity narratives. Emerging Adulthood, 6, 17-31.

\section{STUDY III}

Gyberg, F., Frisén, A., \& Syed, M. (2019) "Being stuck between two worlds" - Identity configurations of occupational and family identities. Provisional acceptance in Identity.

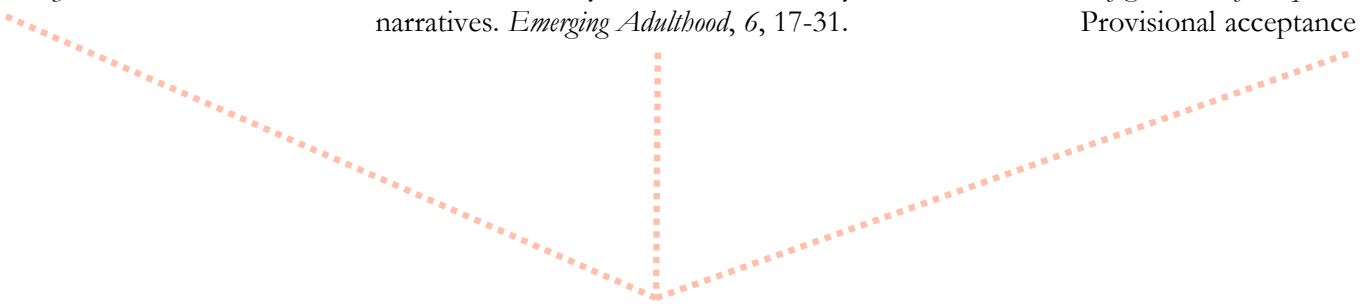

Cultural Context 


\section{SUMMARY OF THE}

STUDIES

As the studies appended to this thesis draw on two different research projects, these projects are briefly described below before continuing with a summary of the three studies.

\section{The GoLD Project}

Studies I and III were conducted within the Gothenburg Longitudinal Study of Development (GoLD), which has been ongoing since 1982 at the Department of Psychology at the University of Gothenburg in Sweden. At the beginning of the project, the participants were recruited from public day care waiting lists and consisted of 144 children between the ages of one and two years. The sample has proved to be representative of children in Gothenburg at that time, in relation to a variety of background variables (see Broberg, 1989). The focus of the GoLD project has changed over the years as the participants have faced different developmental issues. The main focus of the three latest waves of data collection has been on identity development in emerging adulthood and young adulthood. Studies I and III drew on the tenth wave of data collection, including 124 individuals from the original sample (attrition rate 14\%). 


\section{The GREEN Project}

Study II was conducted within the Gothenburg Research on Ethnicity-related Experiences and Identity Narratives project (GREEN), which was a collaboration between the Department of Psychology at the University of Gothenburg in Sweden and the Department of Psychology at the University of Minnesota in the United States. The GREEN project has mainly focused on young people's identity by studying young people's stories about who they are and their everyday experiences. In total, 719 participants were recruited to the study, 437 of whom shared their stories. Study II was conducted on a subsample consisting of the adolescents and emerging adults who wrote about ethnicity-related experiences (see below for more information).

\section{Study I}

\section{Aim}

The aim of Study I was to investigate identity processes (i.e., exploration of and commitment to identity-defining issues) by examining identity status in young adulthood both globally and across central identity domains (i.e., occupation, romantic relationships, parenthood, and work/family priorities), and to determine whether there were any similarities or differences due to gender. Also, we wanted to investigate whether the degree of social comparison orientation differed between young adults assigned to different identity statuses. The following hypotheses were tested:

(1) Based on previous research (e.g., Fadjukoff et al., 2005; Kroger et al., 2010; Pulkkinen \& Kokko, 2000), we expected most young adults to have made identity-defining commitments, being assigned to either identity achievement or identity foreclosure, both globally and across identity domains.

(2) In line with two prior studies (i.e., Pulkkinen \& Kokko, 2000; Shirai et al., 2016), we expected to find no gender differences in global identity status between women and men. Due to the lack of previous relevant research, no hypothesis regarding gender differences in identity status across domains was formulated. 
(3) Although no prior study has investigated the relationship between identity status and social comparison, we formulated the following hypotheses building on theoretical assumptions (see Erikson, 1968; Festinger, 1956). We expected there to be differences in the degree of social comparison orientation among individuals assigned to the different identity statuses globally and across the domains of occupation, romantic relationships, parenthood, and work/family priorities. More specifically, we expected that young adults engaging in identity exploration (moratorium) would score higher in social comparison orientation than would young adults engaging less in identity exploration (foreclosure and diffusion). Also, we anticipated that young adults assigned to moratorium would engage in social comparison more than young adults in identity achievement.

\section{Method}

\section{Participants and Procedure}

Study I is based on the tenth wave of data collection in the GoLD project (see p. 29) and included 124 individuals (mean age 33.29, $\mathrm{SD}=0.54$ ), 62 women and 62 men. All participants were interviewed and given questionnaires, most at the Department of Psychology at the University of Gothenburg; when this was not possible, the participants were interviewed in other public places, such as at universities or libraries in other cities, in their homes, or in a few cases via telephone or Skype. At the time of data collection, $83 \%$ of participants $(n$ $=103)$ were in a romantic relationship and $66 \%(n=82)$ were expecting or had children. Regarding employment, ${ }^{3} 69 \%$ of participants $(n=86)$ were working, $7 \%(n=8)$ were on parental leave, $4 \%(n=5)$ were unemployed or on sick leave, $3 \%(n=4)$ were studying, and $17 \%(n=21)$ were combining work, parental leave, sick leave, and/or studies.

\footnotetext{
${ }^{3}$ As many participants combined several sources of income, employment was operationalized differently in studies I and III in line with the studies' different objectives. In Study I, more distinct categories of employment status were presented, resulting in many participants being described as combining work, parental leave, sick leave, and studies. In Study III, the main source of income was operationalized differently, resulting in a slightly different categorization of participants.
} 


\section{Measures}

Background Interview. All participants were asked about their demographics, housing, employment, and family situations through a structured interview.

Identity Status Interview. To assess identity status, the semi-structured Identity Status Interview was used in accordance with the identity status model (Marcia, 1966; Marcia et al., 1993). A Swedish version of the interview was used (Frisén \& Wängqvist, 2011). The identity domains explored, chosen for their importance during emerging adulthood and young adulthood, were: occupation, romantic relationships, parenthood, and family/work priorities. Several example questions are: "What do you think has influenced your choice of occupational career?"; "Is it important for you to have a long-term relationship?"; "How would you like to be as a parent?"; and "Do you have experience of work/family conflicts?" By assessing the individuals' exploration and commitment as evidenced in the answers, the participants were, in line with Marcia and colleagues (1993), assigned to one of four identity status positions: achievement, foreclosure, moratorium, or diffusion (see pp. 14-16 for descriptions). The inter-rater agreement was $85-90 \%$ with a Cohen's kappa of .70-.89, both globally and across the different domains. All interviewers were trained in using the identity status interview, in terms of both interviewing and assessing identity status, before collecting the data.

Social Comparison. To measure social comparison orientation, we used the first six items of the Iowa-Netherlands Comparison Orientation Measure (INCOM; Gibbons \& Buunk, 1999). One example item from the scale is: "I always pay a lot of attention to how I do things compared with how others do things." Responses ranged from 1 ("I disagree strongly") to 5 ("I agree strongly"). The items used were translated into Swedish for the study by a professional and then back-translated to confirm accuracy. Individual mean scores were calculated, with higher scores indicating a stronger comparison orientation. The Cronbach's $\alpha$ for the present sample was .75.

\section{Data Analyses}

To test the first hypothesis, concerning the distribution of identity status in young adulthood, we explored the frequencies of individuals' assigned identity statuses both globally and across domains. To test the second hypothesis, concerning possible gender differences, we used chi-square analyses and Fisher's exact test. Finally, the third hypothesis, regarding the possible 
relationship between identity status and social comparison, was tested using the Kruskal-Wallis non-parametric test. Significant results were followed up using Bonferroni corrections.

\section{Main Findings}

In line with the first hypothesis, the results indicated that most participants were assigned to an achieved global identity status and had made commitments across domains in young adulthood. In line with the first part of the second hypothesis, we did not find gender differences between women and men in global identity status. Regarding gender differences across domains, we found both similarities and differences between the two genders. Gender differences in identity status were found in the occupational and parenthood domains, with women more often being assigned to identity achievement. Men, on the other hand, were more often assigned to identity foreclosure in the occupational domain and, although few, more men were assigned to identity diffusion in the parenthood domain. Largely contradicting the third hypothesis, most of the identity statuses did not differ in the degree of social comparison orientation. However, there was one exception in the parenthood domain, with those assigned to moratorium scoring higher in social comparison orientation than did those assigned to foreclosure and diffusion.

In sum, reflecting the cultural context in Sweden, where the findings in Study I indicated more similarities than differences in identity status between young adult women and men, gender differences in identity status were present in some areas of life. What can be concluded from the findings is that the studied women more often explored issues of occupation and parenthood before making identity-defining commitments. Our findings also suggest that social comparison may be particularly important for young adults actively exploring issues of parenthood. Taken together, these results bring important knowledge to our understanding of aspects of identity processes in young adulthood. 


\title{
Study II
}

\begin{abstract}
Aim
The purpose of Study II was to investigate ethnic identity content, more specifically, the types of ethnicity-related experiences prevalent in the lives of adolescents and emerging adults in Sweden and whether these types of experiences differed depending on immigrant status, self-identified ethnicity, and age group. The following research questions were investigated:
\end{abstract}

(1) What are the characteristics of youth who choose to write narratives about ethnicity-related experiences?

(2) What is the nature of ethnicity-related experiences for adolescents and emerging adults in Sweden?

(3) Are there any differences in these experiences due to immigrant status, self-identified ethnicity, or age group?

\section{Method}

\section{Participants and Procedure}

Study II was based on a sub-sample of 95 participants (22\% of the 437 participants who shared their stories) from the GREEN project (see p. 30) who wrote narratives about ethnicity-related experiences $(87 \%$ women, $66 \%$ with immigrant backgrounds, $57 \%$ emerging adults, $43 \%$ adolescents, $M_{\text {age }}=$ 19.62). These 95 individuals included more individuals with an immigrant background than without, and more women with an immigrant background than individuals with other combinations of gender and immigrant status. The participants were recruited through visiting six upper secondary schools (three years of education following primary school, normally starting at age 16) and two universities in the west and south of Sweden (i.e., in Gothenburg, Malmö, Falkenberg, and Borås) and informing the students about the study in their classrooms. The participants were then given questionnaires to complete, either on paper or through a web interface. 


\section{Measures}

Background Variables. Participants completed questionnaires in which they reported their age, gender, self-identified ethnicity, and birth country for both themselves and their parents.

Narrative Prompt. To capture the content of ethnic identity, we used a master narrative prompt (Alpert, Marsden, Szymanowski, \& Lilgendahl, 2014; McLean et al., 2017), as it has been shown to be a useful way to capture contextualized identities (see McLean et al., 2017). The prompt was translated into Swedish by a professional and then back-translated to confirm accuracy. The prompt begins with a brief text explaining that life may be viewed as a story and that we all have our own personal stories based on our experiences, stories that may differ from what others expect. This is followed by a question worded as follows: "Have you ever felt that your story diverged from what was considered to be normal, expected, or accepted by family, peers, society etc.?" The prompt was followed by open-ended followup questions building on Syed and Azmitia (2008) to let the participants elaborate on their stories. The followup questions were as follows: (1) "What did you do to handle, resolve, or otherwise make sense of the event?" (2) "How did you feel when this event occurred?" and (3) "Did this event affect what you think about or how you view when/how you deal with difficult problems?" Study II draws on the narratives concerning ethnicity-related experiences.

\section{Data Analyses}

To answer our research questions, a mixed-methods approach (Creswell \& Plano Clark, 2007; Teddlie \& Tashakkori, 2010) was used. In the qualitative part of the study, addressing the second research question capturing the participants' own voices about their ethnicity-related experiences, we used thematic analysis as described by Braun and Clarke (2006) with a narrative approach (see, Adler et al., 2017) to identify both broad themes and more specific subthemes. Overall inter-rater percent agreement between two raters on 55 of the narratives was $86 \%$, with an average kappa of .83 . In the quantitative part of the study, addressing the first and third research questions, we used frequencies, chi-square analyses, and Fisher's exact test to assess the prevalence of the participants' ethnicity-related experiences and analyze whether any experiences were more common in specific age groups, selfidentified ethnicities, or different groups depending on immigrant status. 


\section{Main Findings}

Answering the first research question, the results indicated that more women than men and more people with than without an immigrant background shared stories of ethnicity-related experiences. Further analysis showed that more women with an immigrant background wrote about ethnicity-related experiences than did women without an immigrant background, men with an immigrant background, and men without an immigrant background. Answering the second research question, we found that most of the reported experiences concerned feelings of not fitting in, with six themes being found (see Table 1): experience of prejudice or racism, experience of general difference, experience of being another kind of Swede, experience of distancing to culture, experience of being in between cultures or ethnicities, and experience of cultural ideologies. Furthermore, answering the third research question, the results indicated that more adolescents than emerging adults wrote about the theme experience of being another kind of Swede.

In sum, the themes identified in Study II reflect complex and multicultural identities. The findings reflect the Swedish cultural context and mirror issues of otherness and segregation that may play an important part in many young people's identity formation. The ethnicity-related experiences found in the present study were salient not just for immigrants or a specific age group (except for the another kind of Swede theme) but also for young people in Swedish society in general. Taken together, these results bring important knowledge to our understanding of aspects of identity content in adolescence and emerging adulthood. 


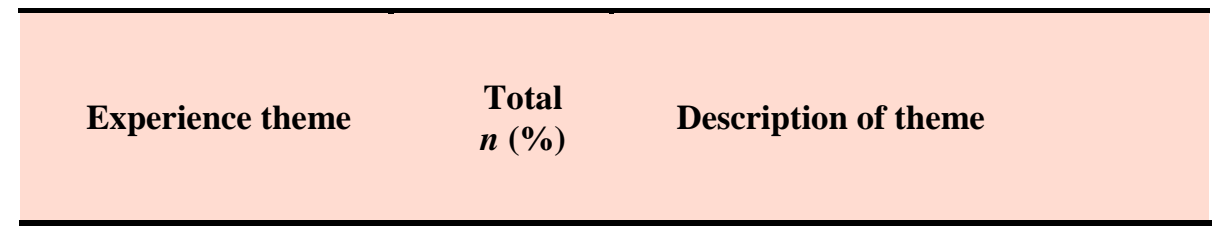

\section{Experience of prejudice} or racism

Experience of general
difference
$29(31 \%)$

Experience of prejudice, discrimination, or racism, or more elaborate thoughts about these issues.

\begin{tabular}{lll}
\hline $\begin{array}{l}\text { Experience of general } \\
\text { difference }\end{array}$ & $26(27 \%)$ & $\begin{array}{l}\text { Experience of being different or } \\
\text { acknowledging others being different } \\
\text { with regard to culture, nationality, or } \\
\text { appearance. }\end{array}$ \\
\hline $\begin{array}{l}\text { Experience of being } \\
\text { "another kind of }\end{array}$ & $13(14 \%)$ & $\begin{array}{l}\text { Experience of identifying oneself as } \\
\text { having a different ethnicity than is } \\
\text { attributed by other people. }\end{array}$ \\
\hline $\begin{array}{l}\text { Expede" } \\
\text { distancing to culture or } \\
\text { ethnicity }\end{array}$ & $13(14 \%)$ & $\begin{array}{l}\text { Experience of distancing to or actively } \\
\text { breaking norms connected to the host } \\
\text { culture or culture of family origin. }\end{array}$ \\
\hline
\end{tabular}

\section{Experience of being in between cultures/ ethnicities} $10(10 \%) \begin{aligned} & \text { Experience of not knowing which } \\ & \text { ethnicity to belong to. }\end{aligned}$ acknowledging others being different with regard to culture, nationality, or appearance.

.




\title{
Study III
}

\begin{abstract}
Aim
The aim of Study III was to investigate identity structure by studying how individuals negotiated their sometimes conflicting multiple identifications of occupation and family to form different types of identity configurations. Also, we wanted to investigate potential gender similarities and differences in the degree of conflict and life satisfaction between the different identity configurations. The following research questions were investigated:
\end{abstract}

(1)

a) What different types of identity configurations are evident as young adults negotiate their work and family identities?

b) Are there any gender differences in the distribution of these configurations?

(2) Does the degree of conflict vary across the different identity configurations?

(3) Do reports of life satisfaction vary across the different identity configurations?

\section{Method}

\section{Participants and Procedure}

Study III is based on the tenth wave of data collection in the GoLD project (see p. 29) and included 124 individuals (mean age 33.29, SD = 0.54), 62 women and 62 men (the same dataset as in Study I). All participants were interviewed and given questionnaires, most at the Department of Psychology at the University of Gothenburg; when this was not possible, the participants were interviewed in other public places, such as at universities or libraries in other cities, in their homes, or in a few cases via telephone or Skype. At the time of data collection, $83 \%$ of participants $(n=103)$ were in a romantic relationship and $66 \%$ of participants $(n=82)$ were expecting or had children. Regarding the main source of income, $77 \%$ of participants $(n=96)$ were working, $7 \%(n$ 
=9) were on parental leave, $4 \%(n=5)$ were studying, $4 \%(n=5)$ were unemployed or on sick leave, and $10 \%(n=13)$ were combining part-time work, parental leave, sick leave, and/or studies.

\section{Measures}

Background Interview. All participants were asked about their demographics, housing, employment, and family situations through a structured interview.

Identity Status Interview. For this study, we only used the work/family priorities domain part of the Identity Status Interview (see description under Study I). To encourage the participants to reflect on work/family priorities, the interviewer began by reminding the participant how they had rated the work, romantic relationships, and parenthood domains on a 1-7-point scale where 1 was "Not important at all" and 7 was "Extremely important." The interviewer then explained that one can have thoughts about how to divide one's time between work and family and that inner conflicts may arise as a result of having to prioritize. The semi-structured interview followed, with the first question asking whether the participant had thought about that type of conflict. Other examples of questions for this identity domain were: "How would you like to prioritize between work and family in your life?" and "Do you have experience of work/family conflicts?" Additional followup questions were asked to encourage the participants to elaborate on their answers.

Life Satisfaction. To measure life satisfaction, we used the Satisfaction with Life Scale (SWLS; Diener, Emmons, Larsen, \& Griffin, 1985). The SWLS is a five-item measure with responses ranging from 1 ("I disagree strongly") to 5 ("I agree strongly"). One example item from the scale is "In most ways my life is close to my ideal." A Swedish version of the scale was used, which has been validated by Hultell and Gustavsson (2008). Individual scores were calculated, with higher scores indicating greater life satisfaction. The Cronbach's $\alpha$ for the five-item scale in the present study was .85 .

\section{Data Analyses}

The three research questions were answered using a mixed-methods approach (Creswell \& Plano Clark, 2007; Teddlie \& Tashakkori, 2010). The qualitative components of the first and second research questions, coding for type of identity configuration and degree of conflict, were explored using thematic 
analysis (Braun \& Clarke, 2006) with a narrative approach (see, Adler et al., 2017). Identity configuration was assessed by investigating how the participants described their prioritizing between work and family in the identity status interviews. Degree of conflict was coded for on a 1-4-point scale, with 1 representing "No conflict" (i.e., no indications of conflict in the interview), 2 "Low conflict" (i.e., indications of minimal or little conflict, happening once or twice with little impact), 3 "Moderate conflict" (i.e., descriptions of conflict as happening sometimes or periodically and not seen as very burdensome), and 4 "High conflict" (i.e., heavy conflict described as an everyday struggle and/or of high intensity). To ensure reliability in the coding, a trained research assistant re-coded $30 \%$ of the interviews for identity configuration (Cohen's $\mathrm{K}=.79,84 \%$ agreement) and an additional $30 \%$ of the interviews for degree of conflict $(\mathrm{ICC}=.90)$. In the quantitative components of the three research questions, we used frequencies, chi-square analyses, and the Kruskal-Wallis non-parametric test. Significant results were followed up using Bonferroni corrections.

\section{Main Findings}

Answering the first research question, we identified six different types of identity configurations, the most common being family first, followed by everything is important, struggling to prioritize, now family comes first, inability to prioritize, and work first (Table 2). Furthermore, the results indicated that there were no gender differences in identity configurations except in the work first configuration, which included only men. Answering the second research question, we found differences in conflict across the different identity configurations. More specifically, participants with a family first configuration reported less conflict than did those with a now family comes first, everything is important, or struggling to prioritize configuration. Participants with a work first or inability to prioritize configuration reported less conflict than did participants with a struggling to prioritize configuration. Answering our third research question, the results indicated differences in life satisfaction across identity configurations. More specifically, participants with an everything is important configuration reported higher satisfaction with life than did participants with a work first or an inability to prioritize configuration. In addition, there was a small positive association between degree of conflict and life satisfaction. 
Table 2. Distribution and descriptions of ethnicity-related experiences among participants.

$\begin{array}{lll}\text { Identity } & \text { Total } & \text { Description of configuration } \\ \text { configuration } & n(\%) & \end{array}$

Family first

$29 \%(n=36)$

Family is the most important thing in life; work is something subordinate, purely for money. This configuration is often described as natural or as a personality characteristic.

Everything is
important $21 \%(n=26)$

Work and family are equally important. Participants want a $50 / 50$ balance, or to maximize everything. Both family and work are part of their identity, so they are reluctant to choose and do not want to or need to prioritize. Often, participants add that if forced to choose, they would choose their families.

Participants want to prioritize family more but cannot. They say that family is the most

Struggling to prioritize

$19 \%(n=23)$ important part of life, although this does not always show in practice. Work generally takes up most of their time, but in a few cases the reverse is the case, and they want to prioritize work.

Both work and family are important, but right now the family role takes first place. Participants Now family
comes first $\quad 12 \%(n=15)$ actively step back from their career, putting it on hold, although it was an important part of who they were. Many participants are open to this changing later on.

Inability to prioritize between work and family is manifested in different ways: participants make brief statements either about not really

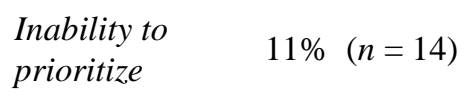
prioritizing or about changing their priorities several times, ending up with very inconsistent narratives; for many, neither work nor family seems important.

Work is the main priority, an active choice sometimes being made to focus on career, opt Workfirst $\quad 8 \%(n=10)$ out of family. For others, family is viewed as something that just happens, and when it does, priorities might change. 
In sum, the findings of Study III reflect the complex and dynamic ways in which young adults structure important aspects of their identities to form different types of identity configurations, emphasizing the importance of the cultural context in which those identities develop. The identified configurations differed conceptually on two dimensions (Figure 5): 1) choosing or not choosing one identity over another, or somewhere in between; and 2) level of certainty, ambivalence, or discrepancy in their prioritization between work and family. Taken together, these results bring important knowledge to our understanding of aspects of identity structure in young adulthood.

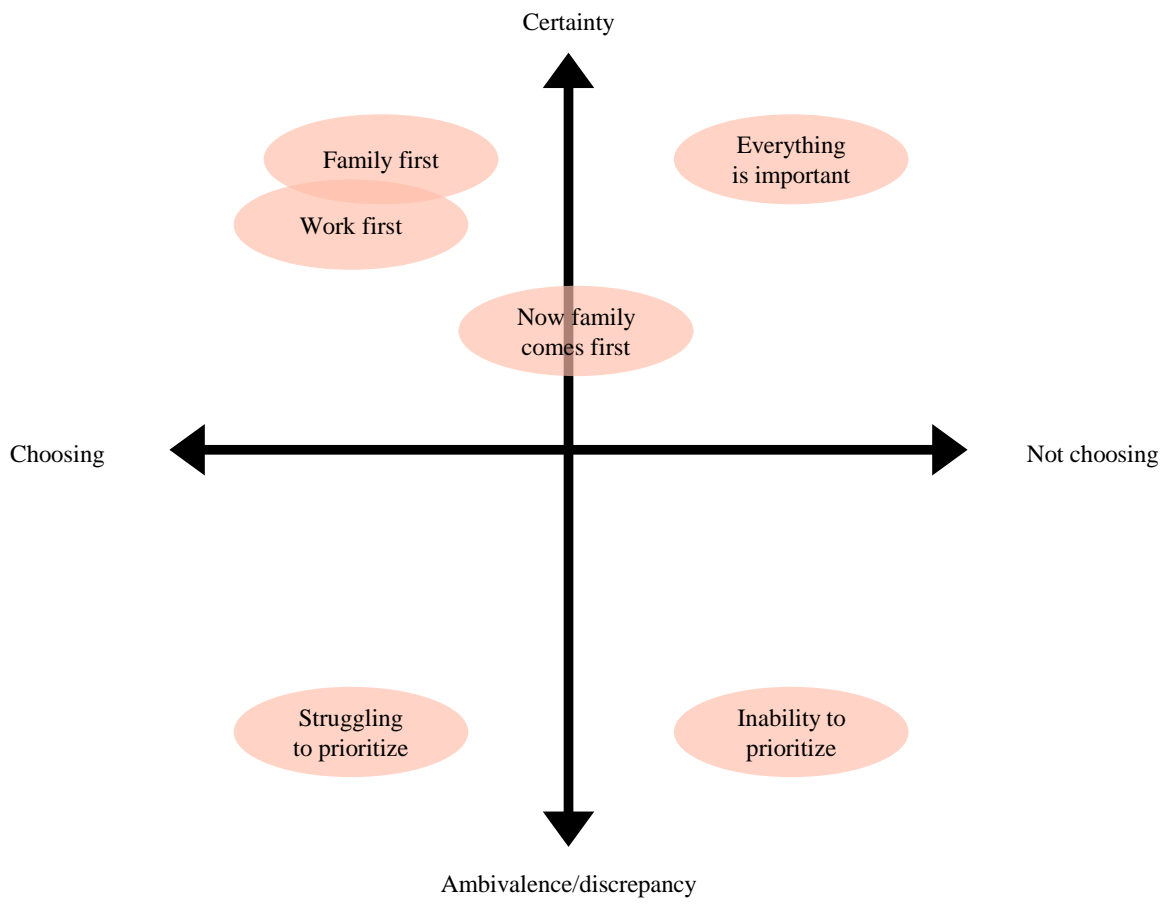

Figure 5. Visual schema of the identity configurations. 


\section{GENERAL DISCUSSION}

The general aim of this thesis was to investigate multidimensional aspects of identity, namely, aspects of identity process, content, and structure, among young people in Sweden using an integrated theoretical approach. More specifically, Study I focused on the identity processes of exploration and commitment globally and across central identity domains among young adults. In addition, gender differences in these processes were investigated as was the relationship with social comparison. The aim of Study II was to investigate identity content in the different types of ethnicity-related experiences narrated by young individuals and whether these experiences differed depending on immigrant status, self-identified ethnicity, and age group. In Study III, identity structure was investigated by studying how young adults negotiated their sometimes conflicting multiple work and family identifications to form different types of identity configurations. Also, potential gender differences, differences in degree of conflict, and differences in life satisfaction between the identity configurations were evaluated. The overall findings are further discussed below, followed by the theoretical, methodological, and ethical considerations. The limitations of the three included studies are then addressed, before the conclusions of this thesis are finally drawn.

\section{Discussing Identity Process}

Using Marcia's (1966, 1993) conceptualization of the identity processes of exploration and commitment, Study I focused on identity status in young adulthood both globally and across important identity-defining domains such as occupation, romantic relationships, parenthood, and work/family priorities. The overall results indicated that most young adults participating in the study had made identity-defining commitments when in their thirties, both globally and across domains. Furthermore, the findings indicated that, although there were more similarities than differences between women and men, several gender differences warrant discussion. In addition, when investigating the 
relationship between people's assigned identity status and social comparison behavior, we only found differences between identity statuses within the parenthood domain. The results of Study I, capturing aspects of identity process, are discussed in the following sections.

\section{Identity Status and Gender}

Focusing on aspects of identity process, as was done in Study I, the overall results indicated that most women and men participating in the study had made identity-defining commitments when in their thirties, both globally and across central domains. These findings add to the notion that most young adults have either an achieved or a foreclosed identity at this time in life (e.g., Kroger, 2007; Kroger et al., 2010; Meeus, 2011), meaning that most people in their thirties have settled on decisions concerning work, family, and the balance between them. Globally, most participants were assigned to identity achievement, meaning that they had made identity-defining commitments after a time of exploration. Others had not explored different options to a large extent, and were assigned to identity foreclosure. Less frequent were participants being assigned to moratorium and identity diffusion, which is not surprising given that most young adults are, as mentioned, expected to have made identity-defining commitments by this time in life.

Although identity status research has seldom found gender differences in global identity status, it has been pointed out that women and men may follow different trajectories across domains (Archer, 1989; Fadjukoff et al., 2005; Meeus \& Deković, 1995; Meeus et al., 2010; Waterman, 1999). This notion corresponds to the results of Study I, as we did not find any gender differences globally but found gender differences in identity status in two domains. Specifically, more women than men were found to have made commitments after a time of exploration (identity achievement) in the occupational domain, whereas men had more often made commitments without exploring different options (identity foreclosure). In addition, more women than men had made commitments after a time of exploration (identity achievement) in the parenthood domain, in which it was also found that only men were among those few assigned to identity diffusion, who had neither explored nor committed to identity-defining issues. These identified gender differences should be seen in light of the gender-equality norm in the Swedish context and the fact that the participants in Study I were the "first children of the gender revolution," as Gerson (2010, p. 3) put it. Being the "first children of the gender revolution" in Sweden means that these participants, born in the early 1980s, have grown up in a society with a pronounced gender-equality norm where there are several societal incentives aimed at, for example, helping mothers 
and fathers to equally share family responsibilities (e.g., Haas \& Hwang, 2000; Swedish Social Insurance Agency, 2018).

As the gender revolution may be seen as primarily affecting women (England, 2010), it may be argued that it is in fact women who have obtained greater space for exploration, not men. For example, it was primarily women who were affected by the gender revolution regarding occupational possibilities, women having been encouraged to enter male-dominated jobs while men have not been encouraged to enter female-dominated jobs to the same extent (England, 2010). This reasoning aligns with the results of Study I in that more women than men had explored before making commitments in the occupational domain, and more men than women had made commitments without exploring identity-defining issues related to occupation. Furthermore, in the Swedish context, both women and men are expected to care for their families alongside having a career (Almqvist et al., 2011; Duvander, 2014; Haas \& Hwang, 2000; Johansson \& Klinth, 2008; Sommestad, 1997). Nevertheless, it is still primarily women who take parental leave and it is still women who are the most responsible for caring for their children (SCB, 2018; Swedish Social Insurance Agency, 2018).

Corresponding to these results, parenthood may therefore be a more pressing issue for women to explore before making commitments, resulting in women being assigned to identity achievement more often than men. The fact that only men - although only a few-were assigned to identity diffusion in the parenthood domain could indicate that parenthood is not as important an identity domain for some men, whereas women are more expected to make some kind of commitment regarding this issue, both in terms of societal norms and due to "the biological clock," a pressure previously identified by Frisén and colleagues (2014). However, as research into identity status among people in their thirties from other cultures than American and Nordic contexts is so far mostly lacking (see Arneaud et al., 2016; Shirai et al., 2016, for notable exceptions), it is difficult to draw any firm conclusions about these patterns. One could question whether the gender differences found in Study I would be the same in other cultural contexts with, for example, more traditional values regarding gender role norms.

\section{Social Comparison and Identity}

When bringing the process of social comparison to the identity status field, as was done in Study I, the results indicated that people exploring identitydefining issues without having made commitments (moratorium) in the parenthood domain engaged in more comparison behavior than did people assigned to foreclosure or diffusion. Theoretically, it was expected that the 
more people explored their identities, the more they would also compare themselves with others, as social comparison is a process of evaluating where one stands in life in relation to others (Festinger, 1954). However, this assumption was not found in the other domains or globally. It is possible that although romantic relationships and work are central domains, young adults have likely had more experience in them than in the parenthood domain, meaning that, during their identity exploration, they do not need to compare themselves with others as much in those domains as in the parenthood domain. As the occupational and romantic relationship domains might have been important for much longer, the need for comparison might not be as strong. This also corresponds to Festinger's (1954) theory of social comparison, which states that the need for social comparison increases the more pronounced the domain. It may be that people use social comparisons in their explorations toward making identity-defining commitments in areas that have new salience, as is the case in the parenthood domain. In the thirties, parenthood is something that does in fact have new salience for many, as most people in Sweden have just started their families at this point in life (SCB, 2019c), which was also true of the participants in studies I and III. Furthermore, seeing that Erikson (1968, p. 87) described the identity-formation process as a "persistent adolescent endeavor to define, overdefine, and redefine themselves and each other in often ruthless comparison," the process of social comparison might be especially important at younger ages when people have less experience in these domains. This question calls for future research in order to fully understand the relationship between identity formation and social comparison across developmental phases.

Although it was only in Study I that social comparison was explicitly brought in and measured, it is clear that the process of comparing oneself with others was treated one way or another in all three appended studies. In Study II, the experience of deviating from the norm was likely to be particularly perceptible through the process of comparison with others. This is especially so when it comes to ethnic identity, which is often made salient when encountering contrasting beliefs and attitudes from various cultures (e.g., Phinney et al., 2000; Verkuyten, 2018). This suggestion is supported by a recent study from the GREEN project by Svensson, Berne, and Syed (2018), which found that others were often used as a contrast or a reference point when identifying oneself. In addition, although not part of the results of Study III, social comparison behavior was evident in the interview material, as several participants used comparisons with others, often their partner, when accounting for their work/family priorities in negotiating their multiple identifications.

Correspondingly, although not explicitly studied in any of the three appended studies, the role of others is apparent in the combined findings of this 
thesis. The role of important others, such as peers, partners, and parents, could therefore be an important avenue for future research on identity development, especially as research has shown that we, for example, develop our identities and personal narratives in relation not only to the cultural context, but also to our family contexts (see Bohanek, Marin, Fivush, \& Duke, 2006; Fivush \& Zaman, 2015; McLean, 2015; Merrill \& Fivush, 2016).

\section{Implications and Future Directions}

Study I sheds light on some of the complex and dynamic aspects of identity process by integrating theories and concepts from both developmental psychology and social psychology. More specifically, Study I contributes to our understanding of identity processes by investigating identity status in a previously understudied age group, assessing gender similarities and differences both globally and across several identity-defining domains, an approach lacking in previous research. In addition, Study I brings the process of social comparison into identity status research, following up on one of the important, but largely neglected, social components of identity formation emphasized by Erikson (1968). The findings of Study I of varying gender similarities and differences in identity status across domains underscore the importance of studying identity in diverse identity-defining domains, as women and men may follow different trajectories of identity development in different domains. Study I also emphasizes the importance of cultural context concerning these different trajectories, as societal norms and expectations are likely to be reflected in the studied processes of exploration, commitment, and social comparison. An interesting avenue for future research would be to conduct a cross-cultural investigation of gender similarities and differences in identity status across identity domains, as this would advance our understanding of how cultural context interacts with processes of identity development. The possibility of relating cross-cultural findings to psychological health outcomes, in light of Côté's (2019) suggestion that people in the Nordic countries may have greater capital for identity exploration than do people in many other countries, would have important implications for policy-makers. In addition, it would be interesting to bring other dimensions of identity to our understanding of the processes of exploration and commitment and their relationship to social comparison. For example, investigating the identity content associated with the studied domains, especially as related to occupation and parenthood, among young adults would be an interesting avenue for future research, as this would enable deeper knowledge of the differences between women and men in terms of exploration 
and commitment and would shed further light on the relationship with social comparison.

\section{Discussing Identity Content}

Through adopting a narrative approach, Study II examined aspects of identity content, more specifically the ethnic identity content of everyday experiences, by exploring ethnicity-related experiences among adolescent and emerging adults in Sweden. In sum, the results reflect complex and multicultural identities and mirror a society where many young individuals struggle to adapt and fit in. The results of Study II are discussed in the following sections.

\section{Ethnic Identity Content in Sweden}

The overall results of Study II, which treated aspects of identity content, indicated that most of the ethnicity-related experiences narrated by the young participants concerned various types of awareness of difference, with stories about not fitting in being common. The feeling of not fitting in may make it harder to achieve an integrated ethnic identity. Having an integrated ethnic identity, meaning feeling part of both one's ethnic group and larger society, is important, as it has been linked to several positive outcomes, such as positive psychological functioning and well-being (Kiang et al., 2008; Quintana, 2007; Rivas-Drake et al., 2014b; Smith \& Silva, 2011; St. Louis \& Liem, 2005; Syed \& Juang, 2014; Wissink et al., 2008). This positive association between ethnic identity and measures of psychological adjustment has also been found in the Swedish cultural context (e.g., Vedder \& Virta, 2005; Virta et al., 2004). However, most of the stories shared by the participants in Study II were about negative experiences.

In line with the master narrative framework (see Galliher et al., 2017a; McLean et al., 2017, 2019; McLean \& Syed, 2015) and in light of the previous studies mentioned, alongside the notions that Sweden has the most integrationpromoting policies in the world (MIPEX, 2015) and is supposed to be one of the top ten countries when it comes to having the happiest people (both native Swedes and migrants; Helliwell, Layard, \& Sachs, 2018), we expected that people deviating from the norms and expectations of Swedish society would have created more positive alternative narratives. This was especially so as previous research by Syed and Azmitia (2008, 2010), using a methodology 
similar to that of Study II, found narratives of connectedness and feeling proud of one's heritage among young people in the United States. In addition, as the results of Study II corresponded to research drawing on theories of acculturation processes in how individuals negotiate and balance multiple cultural orientations (see Berry, 1980; Berry et al., 2006), Svensson and Syed (2019) recently conducted a cross-cultural study comparing identity processes associated with the immigrant experience in Sweden and the United States. Comparing a sub-sample of 29 young participants from the GREEN study and 30 young participants from an American sample, the results indicated that the youth deviating from societal norms in the American sample found a sense of belonging in social groups but that the participants from the Swedish sample did not. Therefore, in line with the results of Study II and of Svensson and Syed (2019), it appears that Swedish youth struggle to find a positive alternative narrative.

The findings of Study II, together with further findings of the GREEN project (i.e., Svensson et al., 2018; Svensson \& Syed, 2019), likely reflect recent public debate in Sweden concerning immigration, in which nationalistic voices are increasingly heard, trying to define what is or is not "Swedish enough" (Hellström \& Nilsson, 2010; Iakimova, 2018; Schierup et al., 2018). Moreover, compared with the United States, Sweden lacks a strong tradition of publicly celebrating diverse cultural heritages, for example, through cultural events and organizations, and ethnicity and culture may not be frequently discussed in public debates other than when negative aspects associated with immigration are brought up. All of these differences may afford fewer opportunities for youth in Sweden, than for youth in the United States, to have positive experiences in which they connect to their ethnic backgrounds. Yet there are, as mentioned, several integration-promoting policies in Sweden, such as native language education, that could be suggested to reinforce positive ethnicity-related experiences. However, this was not reflected in our findings. Future research is needed to understand the gap between societal policies and people's lived everyday experiences, especially as this gap recurs in various ways in all three appended studies.

When exploring the specific ethnic identity content in Study II, we found six different themes: experience of prejudice or racism, experience of general difference, experience of being another kind of Swede, experience of distancing to culture, experience of being in between cultures or ethnicities, and experience of cultural ideologies. One of the most common types of ethnicityrelated experiences was that involving prejudice and racism, as also found in research from the United States (e.g., Syed, 2015; Syed \& Azmitia, 2008, 2010). Discrimination and racism are serious problems with several negative psychological consequences for the individual exposed to them (see Pascoe \& Smart Richman, 2009, for a meta-analysis). However, it has been found that 
group identification serves as a factor protecting against the possible negative health effects associated with perceived discrimination (Pascoe \& Smart Richman, 2009). Nevertheless, many young people in Sweden may lack such protective group identifications, as most of the stories identified were about not fitting in. This suggestion was further supported by Svensson and Syed (2019), who found that youth with bicultural backgrounds in Sweden have a harder time finding group belonging than do bicultural youth in the United States. This observation is also applicable to two of the other common types of ethnicity-related experiences identified in Study II, more specifically, experience of being another kind of Swede and experience of being in between cultures or ethnicities.

In Sweden, it may be difficult to live up to the normative expectation of being "Swedish enough," and it may be even more difficult to feel at home and self-identify in terms of ethnicity due to the notion that, in Swedish society, one is generally viewed either as a Swede or an "immigrant" (Almqvist, 2006; Johansson \& Olofsson, 2011; Scuzzarello \& Carlson, 2018; Svensson et al., 2018). Not feeling at home in any of these broad, yet restrictive, identifications may create ambivalence between them, both renegotiating and reinforcing the duality of being an immigrant and a Swede simultaneously (Wikström, 2007). The stories about experience of distancing to culture may also be understood in light of this reasoning, as it can be viewed as a way of guarding against being the marginalized and stigmatized immigrant, by attempting to fit the norm of being a Swede (Johansson \& Olofsson, 2011; Wikström, 2007). The distancing may also be an effect of assimilation norms in Swedish society, where there has been increased public debate about immigration, sometimes incorporating nationalist rhetoric (Hellström \& Nilsson, 2010; Iakimova, 2018; Schierup et al., 2018). The experience of being a minority can make ethnicity a more salient aspect of identity, raising questions about having to navigate between "two worlds" (García Coll \& Marks, 2012; Umaña-Taylor et al., 2014). It has been suggested that youth with an immigrant background are especially prone to feeling this type of "in-betweenness," which may affect their identity formation due to difficulties with ethnic identity integration (Sam \& Berry, 2010). Another factor that may hinder protective group identifications is the issue of not having language with which to discuss one's identifications and who one is. Swedish society mostly lacks accepted "hyphenated identities" (Scuzzarello \& Carlson, 2018; Svensson et al., 2018), such as Asian-American or British-Somali, a lack that may increase the feelings of marginalization and otherness. Having words that allow for and encourage the integration of multiple identifications may be important, as research has shown that having multiple ethnic identities is associated with several positive psychological outcomes (Kiang et al., 2008; Quintana, 2007; Rivas-Drake et al., 2014b; 
Smith \& Silva, 2011; St. Louis \& Liem, 2005; Syed \& Juang, 2014; Wissink et al., 2008).

\section{For Whom is Ethnic Identity an Important Domain?}

The results of Study II indicate that ethnicity-related experiences may be important and pressing for many young people in Sweden, as $22 \%$ of the participants chose to write about such experiences when asked an open-ended question encouraging them to narrate what separated them from what was expected or accepted by others or society. Unsurprisingly, it was mostly individuals with an immigrant background who wrote about ethnicity-related experiences. This result corresponds to previous findings suggesting that ethnic identity may be especially important for those belonging to a minority group (Phinney, 1990; Phinney et al., 2000; Umaña-Taylor et al., 2014). However, $78 \%$ of the original sample did not write about ethnicity-related experiences. Hence, although we all have an ethnicity, it may not be an important part of everyone's identity, recalling the above discussion of the domain of parenthood in Study I. Furthermore, Study II demonstrated that it was common for women with an immigrant background to share ethnicityrelated experiences. This could be explained by theories of intersectionality (see, Cole, 2009; Crenshaw, 1991; Ghavami, Katsiaficas, \& Rogers, 2016; Syed \& Ajayi, 2018), which posit that having two or more subordinate group identities tends to make ethnicity-related experiences even more pronounced. However, other group identities, such as social class, gender, or belonging to a specific ethnic group, may be important for the salience of ethnic identity. For example, it is possible that ethnic identity may be more pronounced for a working-class woman of African background than for a middle-class man of European background, as the former would have several subordinate group identities.

No differences across the different ethnicity-related experiences were found to be attributable to immigrant status or self-identified ethnicity; however, the stories told by the participants were not always solely about the participants themselves, but could be about friends or family members, which could explain why. Similar non-significant results were found when comparing age groups, with one exception. For the theme experience of being another kind of Swede, more adolescents narrated this type of story than did emerging adults. This result could be interpreted from a developmental perspective in which adolescence is a period with more pronounced role expectations than is emerging adulthood (Arnett, 2006, 2015). In other words, it may be more important for adolescents to label themselves as belonging to one specific ethnicity. Furthermore, it has been suggested that it is in adolescence that an 
understanding of shared (or unshared) experiences of ethnic identity become particularly relevant (Umaña-Taylor et al., 2014). However, most of the narratives captured by the themes seem to convey common ethnicity-related experiences among young people regardless of age.

\section{Implications and Future Directions}

Study II shed light on some of the complex and dynamic aspects of identity content by integrating theories and concepts from developmental psychology, personality psychology, and social psychology. More specifically, Study II contributes to our understanding of identity content by investigating ethnicityrelated experiences and ethnic identity content among adolescents and emerging adults in Sweden. Although Sweden is ranked as having the most integration-promoting policies in the world (MIPEX, 2015), for example, offering native language education, which is thought to strengthen the sense of belonging to multiple ethnic identifications, the stories from Study II indicate otherwise. The finding of ethnicity-related experiences being mostly negative is important, as it underscores the need to address issues of negative attitudes toward immigration and discrimination in Swedish society. Addressing these issues may be particularly important for anybody working with adolescents and emerging adults, since public debate in Sweden has tended to focus on economic and social issues concerning immigration and not on peoples' lived experiences. The findings of Study II also further emphasize the need to take identity content into account, as studying this content may engender valuable insights that scale measures sometimes cannot capture. An interesting avenue for future research would be to further investigate ethnic identity development by bringing in other dimensions of identity, such as identity structure, for example, by studying how young people in Sweden of immigrant descent configure their multiple ethnic identifications into a reasonably workable whole. An important question would be what distinguishes those who can successfully integrate multiple ethnic identities to form a sense of self, as this, as previously mentioned, has been shown to be associated with multiple positive psychological outcomes (Kiang et al., 2008; Quintana, 2007; RivasDrake et al., 2014b; Smith \& Silva, 2011; St. Louis \& Liem, 2005; Syed \& Juang, 2014; Wissink et al., 2008). There might be differences in underlying identity processes and different possibilities to explore in this domain depending on, for example, gender or socioeconomic background. Additionally, it would be useful to further investigate ethnic identity content cross-culturally, outside the United Kingdom and the United States, to improve our understanding of how cultural norms and expectations may influence our 
narrative identities. Answering these questions would have valuable implications for how to promote positive identity integration.

\section{Discussing Identity Structure}

By adopting a narrative approach using the identity status interview, Study III focused on aspects of identity structure by investigating the identity configurations of occupational and family identities among young adults in Sweden. The overall results indicated different ways of negotiating between conflicting work and family identifications diverging on two dimensions: 1) choosing or not choosing one identity over another and 2) level of certainty or ambivalence in the prioritization between work and family. In addition, although there were more gender similarities than differences, one configuration included men only. We also found differences in conflict and life satisfaction between different identity configurations. The results of Study III, capturing aspects of identity structure, are discussed in the following sections.

\section{Identity Configurations of Occupational and Family Identities}

The results of Study III indicated six different ways of configuring occupational and family identities, the most common being family first, followed by work first, now family comes first, everything is important, struggling to prioritize, and inability to prioritize. These different ways of negotiating between occupational and family identities diverged on two dimensions: 1) choosing (i.e., family first, work first, and struggling to prioritize) and not choosing (i.e., everything is important and inability to prioritize) one identity over another, with some participants found in the middle, having it both ways (i.e., now family comes first); and 2) level of certainty or ambivalence in the prioritization between work and family.

There were three different types of identity configurations in which the participants chose one identification over another, namely, family first, work first, and struggling to prioritize. The occurrence of choosing one identification and suppressing another has been found in previous research and may be viewed as a way to minimize the internal conflict between identifications (Hammack, 2010; Schachter, 2004). This suggestion is supported by the finding that the participants choosing family first, which was 
chosen with certainty, were assessed as experiencing the least conflict. Similarly, the work first configuration was also found to be among the identity configurations with the least conflict. However, the participants struggling to prioritize between work and family were found to experience significantly more conflict than did the participants choosing family first or work first. Although they had chosen one identification over another, they struggled to realize this prioritization in everyday life, which might reflect some of the inconsistencies seen in Swedish society, where the norms, attitudes, and policies do not always match everyday practices (Almqvist et al., 2011; Magnusson, 2008; SCB, 2018).

From a developmental perspective, the finding that the family first configuration was the most common configuration is unsurprising, as the participants were at a time in their life when the family becomes salient, with new role expectations that need to be integrated into their sense of self, as many people at this age have started or are planning to start their own families (Arnett, 2012, 2015; SCB, 2019c). In addition, there are strong family-centered norms in Sweden, parallel to norms of gender equality (Björnberg, 2002; Elvin-Nowak \& Thomsson, 2001; Sommestad, 1997). In line with this reasoning, the work first configuration was the least common among the participants, though all those coded to it were men. That it was as uncommon as it was reflects the dual norms in Swedish society, where family values are important alongside sharing responsibilities (Björnberg, 2002; Magnusson, 2008; Sommestad, 1997). Corresponding to the findings of Study I, it may also be that, for some men, family is not an important area of life. This is supported by the fact that none of the participants coded to a work first configuration had children and less than half of the men were in a romantic relationship. Still, many of these men were open to the suggestion that when "family happened," they might change their priorities. This reasoning may be a way for some of these men to handle not living up to the norms and expectations of Swedish society, in terms of both gender role norms and family norms. In addition, the results indicated that these men had lower life satisfaction ratings than did the participants with an everything is important configuration. This corresponds to the suggestion that family and friends are the most important influences on life satisfaction (Diener, 2006).

On the dimension of not choosing one identification over another, the second most common and the second least common identity configurations were found, namely, the more certain configuration everything is important and the more ambivalent inability to prioritize configuration. Not wanting to choose between identifications, as was the case for the participants considering both occupation and family extremely important, may be especially salient and reflective of the expectation in Swedish society that one should succeed on all fronts, which might have been internalized in the participants' sense of self. 
This resonates with Schachter's (2004) suggestion that prioritizing one identification over another could, for some people, be equivalent to rejecting part of themselves. Although the participants considering everything equally important were assessed as having more conflict that those choosing family first, and noticeably struggled with balancing work and family, they also reported more life satisfaction than did participants unable to prioritize and those choosing work first. As mentioned, this finding corresponds to the suggestion that life satisfaction is highly influenced by social relationships, such as family and friends, as well as by performance-based roles, such as occupation (Diener, 2006). Another explanation could be that the lower life satisfaction is an effect of not living up to the cultural norms and expectations of Swedish society, in terms of both having it all and family-centered norms (Björnberg, 2002; Elvin-Nowak \& Thomsson, 2001; Sommestad, 1997). In addition, as has been discussed in relation to ethnic identity, having multiple identifications is argued to serve as a protective factor against negative experiences versus having only one or no identifications (Barnett \& Hyde, 2001). These suggestions may also account for the positive relationship found between degree of conflict and life satisfaction. However, future research is required to confirm this observation and better understand the relationship between internal conflict and measures of subjective well-being. Standing in contrast to wanting it all was the inability to prioritize configuration, in which the participants did not seem to find either work or family to be important to who they were. It might be that these participants lack direction in life and a sense of meaning and purpose (Côté, 2019; Kroger \& Marcia, 2011), which aligns them with the participants assigned to identity diffusion in Study I. The ambivalence shown by the participants coded to the inability to prioritize configuration could also indicate that this configuration is in its early stages formalizing, still being very loose without a clear structure. It may also be that these participants find other areas of life more important for who they are as people. The fact that more than two thirds of the participants with an inability to prioritize were in romantic relationships and about a third of them had or were expecting children further supports the notion that identity is not merely where one is positioned in terms of these domains.

The identity configuration in which participants both choose an identification and leave a door open to choose differently in the future, as seen in the now family comes first configuration, may highlight how identity configuration is also an ongoing process of negotiating and renegotiating multiple identifications over time (Dahl \& Galliher, 2012; Hammack, 2010; Syed, 2010). Furthermore, this way of negotiating multiple identifications may be a way to minimize the conflict in having to reject one identification fully, even though it does not seem all that successful given that the participants with 
a now family comes first configuration experienced more conflict than did those choosing family first.

Moreover, the lack of gender differences in configurations of occupation and family identities might be surprising given that relational domains of identity often are considered more important for women (Archer, 1989; Fadjukoff et al., 2005; Lewis, 2003). However, these findings may be especially reflective of the Swedish cultural context, emphasizing genderequality norms concerning work and family (Almqvist et al., 2011; Duvander, 2014; Haas \& Hwang, 2000; Johansson \& Klinth, 2008; Sommestad, 1997) and making it more accepted for men to care for the family. This suggestion is also supported by the lack of gender differences in identity statuses found in the work/family priorities domain in Study I.

\section{Implications and Future Directions}

Study III shed light on some of the complex and dynamic aspects of identity structure by integrating theories and concepts from developmental psychology, personality psychology, and social psychology. More specifically, Study III builds theoretically on prior identity structure research, finding that there are numerous ways of achieving what Erikson $(1956,1968)$ described as identity synthesis. Moreover, the findings emphasize how identity configuration is an ongoing process that is highly dependent on cultural context (Dahl \& Galliher, 2012; Hammack, 2010; Hammack et al., 2009; Schachter, 2004, 2005a; Syed, 2010). The configurations identified in Study III likely mirror the duality of having both strong family-centered norms and strong gender-equality norms in Sweden, where both women and men are expected to both have a career and care for the family, while it is often difficult to live up to these expectations in everyday life (Almqvist et al., 2011; Elvin-Nowak \& Thomson, 2001; Duvander, 2014; Haas \& Hwang, 2000, 2019; Johansson \& Klinth, 2008; Sommestad, 1997). The finding from Study III that the participants who found both occupation and family important for who they were reported higher life satisfaction than did those who prioritized work or did not prioritize anything, may reflect the norm in Sweden of having it all. However, negative psychological outcomes might still be associated with experiencing high internal conflict. For example, it may be that these individuals also experience high levels of stress. Future research should investigate psychological health among people with high conflict between their identifications to better understand the ongoing process of identity configuration. Likewise, it may be useful to further investigate the processes involved in configuring one's identifications, for example, by investigating how the processes of exploration and commitment vary between different identity configurations, as there might 
be, as previously suggested, some similarities between different identity statuses. Furthermore, both studies II and III illustrate the importance of being able to have multiple identifications, for example, to be both Swedish and Iranian, or both a lawyer and a mother. Having several central identifications does not necessarily mean being less of a complete person, less Swedish, less Iranian, less of a lawyer, or less of a mother. Having multiple identifications that are configured into a workable whole may in fact serve as an empowering and protective factor associated with positive psychological health outcomes (Barnett \& Hyde, 2001; Kiang et al., 2008; Quintana, 2007; Rivas-Drake et al., 2014b; Smith \& Silva, 2011; St. Louis \& Liem, 2005; Syed \& Juang, 2014; Wissink et al., 2008). Society needs to allow for, and encourage, multiple identifications, not only in terms of policy, but also by allowing for and facilitating this in everyday life.

\section{Theoretical Considerations}

Although the present studies have expanded our knowledge in the field of identity, several questions remain to be answered. Also, there are additional possible ways of integrating the various theories used to capture the different dimensions studied in this thesis. The three studies have not fully integrated all discussed aspects of identity theories and concepts, for example, the process of social comparison orientation in studies II and III, or narrative identity content in Study I. Also, as all three studies were cross-sectional, only snapshots of identity formation were captured. Future studies would accordingly benefit from longitudinally investigating the identity aspects considered here, namely, the identity processes of exploration and commitment, gender, social comparison, ethnic identity, identity configurations, conflict, and life satisfaction, in order to capture stability and change in content, process, and structure over time. Furthermore, it is important to acknowledge that there are other theories of identity not considered in this thesis but that still might foster important insights when trying to capture the "whats" and "hows" of identity formation (e.g., Burke \& Stets, 2009; Gergen, 1991; Josselson \& Harway, 2012; Stryker, 2008). Still, including three of the major identity theories with the aim of integrating them is a first step toward offering a more holistic and multidimensional understanding when answering the question "Who am I?"

All three constituent studies of this thesis combined aspects of different identity theories. In Study I, we used Marcia's (1966) identity status model, derived from Erikson's identity theory, in order to capture identity processes, and we also measured social comparison, which is an important aspect of social 
identity theory. In Study II, we focused on identity content by investigating ethnic identity, a concept derived from both Erikson's (1968) identity theory and social identity theory (Tajfel \& Turner, 1979, 1986). We conducted the study using a narrative approach, including narrative identity theory (McAdams, 1993, 2001) in the study design and in interpreting the results of the study. In Study III, we studied identity structure using Erikson's (1968) concept of identity configurations, which we integrated with narrative identity theory (McAdams, 1993, 2001). Each of these perspectives on identity has characteristic strengths and weaknesses. Although the psychosocial perspective in developmental psychology positions itself as combining nature and nurture, it is sometimes criticized for primarily concerning itself with individual processes and psychological growth theorized as universal developmental stages (e.g., Arnett, 2015), not taking cultural context, socioeconomic status, ethnicity, or gender into account (Lalander \& Johansson, 2007). However, few other theories have been able to capture identity processes at an individual level over time, as has been done in the Eriksonian field of identity (see Kroger \& Marcia, 2011). Although identity researchers increasingly acknowledge the value of studying narrative identity (e.g., Arnett, 2015; Kroger, 2015; Syed \& McLean, 2015), the approach has certain acknowledged limitations. The narrative perspective has been criticized for having difficulties generating general conclusions of identity development (Ferrer-Wreder \& Kroger, 2019; Kroger, 2007). Still, the narrative approach is able to capture the actual content of what constitutes identity (Syed \& McLean, 2015). As for the sociocultural perspective on identity, used mostly by social psychologists, it has been criticized for primarily emphasizing social processes and interpersonal relationships, not taking inner processes or the subjective meaning of identity into account (e.g., Huddy, 2001; Kroger, 2007). However, the sociocultural approach takes context into account to a much greater extent than does the psychosocial approach (Kroger, 2007). These abovementioned limitations may best be addressed, as done in this thesis, by approaching identity from various perspectives and using multiple methods (e.g., Côté, 2015; Ferrer-Wreder \& Kroger, 2019; Kroger \& Marcia, 2011; Pasupathi, 2014; Schachter, 2013; Schwartz et al., 2015; Syed \& McLean, 2015; van Doeselaar et al., 2018).

As no researcher acting alone can fully uncover the process, content, and structure that together constitute identity, we need to work together. Instead of pitting theories against each other, we need to see them as supplying different pieces of the puzzle of identity. As Côté (2015) argued, there is a need to be judgment free and open to other theories and ideas. We need an integrated approach to the complex concept that is identity, otherwise we will not succeed in moving forward. That is what has been argued to be the future of identity research by many researchers in the field (Arnett, 2015; Côté, 2015; Ferrer- 
Wreder \& Kroger, 2019; Kroger \& Marcia, 2011; Pasupathi, 2014; Schachter, 2013; Schwartz et al., 2015; Syed \& McLean, 2015; van Doeselaar et al., 2018). This thesis, and its constituent studies, adds several new pieces to the puzzle of identity research, in its attempt to integrate identity theories and to take cultural context into account.

Furthermore, it has been questioned whether the identity status model is the best way to capture Erikson's theory of identity (see Schwartz, 2001; Schwartz et al., 2015), especially as differences in identity processes are somewhat difficult to capture using quantitative measures after commitments have been made (McAdams \& Zapata-Gietl, 2015). There have been other ways of implementing and theorizing Erikson's theory of identity, aiming at capturing the underlying developmental processes of exploration and commitment (Crocetti \& Meeus, 2015). For example, a dual-cycle model (see Crocetti, Rubini, \& Meeus, 2008; Luyckx, Goossens, \& Soenens, 2006; Luyckx, Goossens, Soenens, \& Byers, 2006; Meeus et al., 2010) has been developed to capture different types of exploration. Still, using qualitative measures, such as Marcia's original identity status interview (Marcia, 1966; Marcia et al., 1993), to capture the processes of exploration and commitment, as done in Study I, allows for a more in-depth analysis capturing identity development even when commitments have been made, as is often the case in young adulthood. A further advantage of using qualitative methods, such as the identity status interview, is that it allows the capturing of identity processes across identity domains and cultural contexts, which may be more difficult using quantitative approaches. Thus, the identity status model may still have significance, and unexplored areas remain where this model may shed further light on the processes of identity formation (McAdams \& Zapata-Gietl, 2015).

In addition, it merits consideration whether identity status really is a representation of identity processes or a way of understanding identity structure. I argue that identity status could be understood both ways, especially when mapping it across domains. Identity status may be both a way of understanding identity processes in how people have explored and committed to various identity-defining issues as well as a way of understanding how identity status is structured and corresponds across domains (e.g., achieved in one domain and moratorium in another). There has been some notable work on identity structure by investigating the stability and instability of identity processes such as exploration and commitment across domains and over time (e.g., Crocetti, Scrignaro, Sica, \& Magrin, 2012; Luyckx, Seiffge-Krenke, Schwartz, Crocetti, \& Klimstra, 2014). However, the term identity configurations as used in this stream of research is unfortunate given that it does not capture identity configurations as Erikson described them (see Erikson, 1968; Schachter, 2004, 2013) or as the term is used in this thesis. 
In line with Galliher and colleagues' (2017a) model of identity content, Study II included the investigation of ethnic identity content, focusing on the most proximal level of content, namely, everyday experiences. Although not specifically studies of identity content, both studies I and III tapped into levels of content, with Study I assessing identity processes across identity domains and Study III focusing on identity structure by investigating negotiations of identity domains. Furthermore, all three studies took cultural context into account. Thus, the appended studies in this thesis not only included the level of everyday experiences, but also the levels of cultural context and identity domains. Still, one level of content has been somewhat neglected in this thesis, namely, social roles. Social roles, such as social identity and relational identity, are very important for who we are (Galliher et al., 2017a; Simpson \& Carroll, 2008), and although Study I takes account of social comparison, an important process in social identity formation, none of the constituent studies of this thesis looks more closely at social aspects beyond the individual. As previously discussed, the role of others is important to consider in future research seeking to understand aspects of identity.

Lastly, it is open to discussion whether identity configurations also could be understood as identity process or as identity content. As with identity status, I believe that identity configurations could be understood several ways. Configuring one's multiple identifications may be viewed as an ongoing process of structuring one's identity while realizing the content involved (Dahl \& Galliher, 2012; Galliher et al., 2017a; Hammack, 2010; Hammack et al., 2009; Schachter, 2004, 2005a; Syed, 2010). Study III is a good example of this, as the different configurations both highlight the ongoing negotiations of conflicting identities among many of the participants and reflect the content encompassed in the identified configurations. As mentioned in the introduction, the process, structure, and content of identity are in reality impossible to definitively separate from one another, at the same time as it is necessary to do so to better understand these identity dimensions and how they are connected. Thus, this thesis and its three appended studies allow for a multidimensional understanding of identity, offering new theoretical insights into the answer to the fundamental question "Who am I?" 


\section{Methodological Considerations}

\section{Data Collection Methods and Measures}

A cross-sectional design as used in all three appended studies inhibits us from drawing any conclusions on how the studied dimensions of identity evolve over time. More longitudinal research is therefore needed in order to understand the temporal aspect of identity process, content, and structure. Moreover, in studies I and III, data were collected through interviews. With the interview format come challenges of social desirability, and of responses being affected by the interviewer-respondent relationship (Bourne, 1978). However, all interviewers were thoroughly trained in adopting an open attitude and in asking follow-up questions. Furthermore, using interviews to establish identity status has been criticized for relying too much on people's verbal abilities (van Hoof, 1999). However, both the interview and coding manuals were developed to minimize the risk of confounding variables (Marcia et al., 1993). In addition, using the Identity Status Interview to capture identity structure as we did in Study III may have yielded specific types of identity configurations and precluded others through the way the interview and its questions were structured. It may also be that other types of identity configurations than those found are present in other identity domains, which is an important avenue for future research. For example, the participants wanting and having it all examined in Study III may also be wanting it all in other identity domains, which likely also has an effect when prioritizing between work and family. In sum, the advantages of the interview format outweigh its disadvantages, in that it yields a large quantity of rich data that might have been lost using another data collection method.

Using a self-report measure of social comparison orientation, as was done in Study I, limits our in-depth understanding of what constitutes the process of comparing oneself with others. We used only a short version of INCOM (Gibbons \& Buunk, 1999) due to space and time constraints. It is therefore possible that we could not fully capture social comparison. Still, the shortversion scale has been found to be a valid representation of the full scale (Gibbons \& Buunk, 1999). In addition, a narrative approach might have been more suitable for capturing the relationship between social comparisons and identity, as the status paradigm has been criticized for being too static and being unable to capture identity development after identity-defining commitments have been made, as would be expected in most domains in young adulthood (McAdams \& Zapata-Gietl, 2015). Therefore, analyzing qualitative data on the content of the identity-social comparison relationship could yield 
important knowledge of the types of comparisons used and of those with whom people compare themselves.

In Study II, data were collected using a narrative prompt, which entails a few limitations. One concern is that it may not be representative to draw conclusions based on a single self-reported memory, as several surrounding factors may affect what memory comes to mind (e.g., Syed, 2015). However, the same concern applies to other methods of measuring psychological experiences. Also, using an open prompt, as was done in Study II, permits a variety of interpretations and answers. For example, we could have asked directly about ethnicity-related experiences, which might have resulted in different types of narratives. Still, asking a broad question allowed us to investigate the individuals for whom ethnicity-related experiences were especially salient. In addition, it has been suggested that using a narrative approach allows people's own voices to be heard, which is difficult to do using scale measures (Syed, 2015). Identifying themes about not fitting in when asking for narratives about what separates someone from what is expected may not be that surprising. In addition, one might question whether the narratives really reflected identity. Several studies using a master narrative framework have shown that deviating from cultural norms is associated with more identity work within the relevant domains, as individuals need to explain their deviations, in turn making the deviations seem more central to identity (see McLean et al., 2016, 2017, 2018). As a result, individuals deviating from societal norms and expectations often construct alternative narratives, which often also include more positive stories of connectedness and group belonging, in addition to acknowledging differences or marginalization (see McLean et al., 2017, 2018; Syed \& Azmitia, 2008, 2010). Also, eliciting themes by asking a broad question, as was done with the master narrative prompt (Alpert et al., 2014; McLean et al., 2017), encourages young people to reflect on themselves in relation to societal norms, allowing for qualitatively different experiences to be reported, as seen in the results of Study II.

The results of Study II indicated that none of the themes found was more common depending on immigrant status or self-identified ethnicity. However, it may be argued that our conceptualization of immigrant status as having at least one parent born outside Sweden is far too simple. For example, the experience of integration in Swedish society could well be very different for a person born in Sweden, with one parent born in Sweden, compared with that of a person not born in Sweden or with both parents born in another country. Therefore, we also tested for this, but found no difference in the reported experiences. It may still be that ethnicity-related experiences differ depending on, for example, the specific ethnic group to which individuals belong, age at arrival in Sweden, social context, and family context. Similarly, there may be individuals coded as having no immigrant background although they share the 
experience of not fitting in due to ethnicity, as they might be the grandchildren or great grandchildren of people who immigrated to Sweden, a matter that we did not collect information about. This is important for future research to consider, in order to better understand ethnic identity formation.

Furthermore, it may be that the self-report measure of life satisfaction used in Study III does not capture enough aspects of psychological wellbeing. In addition, it is important to highlight that even though internal conflict and life satisfaction were correlated positively in Study III, there might, as previously mentioned, be other negative psychological outcomes that the participants with high conflict are at risk of being subjected to, such as high levels of stress. Another possible way of understanding this positive correlation is that participants in high conflict configurations may be more prone to social desirability, as they are the ones living up to societal expectations of doing it all, both having a career and focusing on their families. However, some studies argue that social desirability does not affect subjective measures of well-being (e.g., Pavot \& Diener, 2009). In addition, the measure of degree of conflict that was coded for in the interviews of Study III may not have captured all aspects of internal conflict associated with negotiating multiple identifications. Additional associations might be found using a more standardized measure of conflict than coding for it using a thematic analysis approach, which may create issues of internal consistency, especially since we only re-coded $30 \%$ of the interviews to confirm inter-rater reliability. Future research is therefore required to more fully uncover the associations between internal conflict and psychological health outcomes.

\section{Data Analyses}

Concerning data analyses, certain limitations warrant discussion. First, all three studies have major power issues due to sample size constraints that limit both the type of analyses that could be conducted as well as the generalizability of the results. Despite the sample size constraints prohibiting more complex quantitative analyses, all three studies have relatively large samples in relation to the qualitative measures used, and they all yield valuable information on aspects of identity process, content, and structure that have previously been understudied. Nevertheless, the small sample sizes prevented us from taking a more intersectional approach to identity. In this thesis, I have discussed how norms concerning ethnicity and gender may affect people's identities, but none of the studies in itself investigated how gender intersects with, for example, ethnicity or social class in relation to people's identities. This is a limitation of all three studies due to sample size constraints and study design, as our quantitative analyses relied on the categorical grouping of data, which arguably 
has difficulties capturing the complexity of intersectionality (e.g., Bowleg, 2008; McCall, 2005). Future studies would therefore benefit from incorporating an intersectional approach to capture the complexity of identity more fully.

Moreover, there is a risk of type-II error in studies I and III, in that the small sample sizes might make it difficult to find effects due to issues of power. Similarly, using the Bonferroni correction as done in studies I and III might also increase the risk of type-II error. Furthermore, although we performed non-parametric tests in studies I and III, we could not test for interaction effects in the relationship between the identity dimensions studied, gender, and social comparison in Study I and between degree of conflict and life satisfaction in Study III. Therefore, future research would benefit from using larger samples when investigating gender differences in various dimensions of identity and associated psychological outcomes.

Furthermore, in Study I, very few or no participants were assigned to moratorium or identity diffusion when we investigated gender differences in identity status across domains, which makes it difficult to draw firm conclusions. However, the small number of people assigned to moratorium or identity diffusion corresponds to the results of the few identity studies examining people in their thirties (see, Kroger et al., 2010; Meeus, 2011). Studying the relationship between identity status and social comparison at younger ages could be beneficial, as more people would be expected to be assigned to moratorium, meaning that they are actively exploring these issues and are therefore more prone to comparing themselves with others in their quest to find out who they are and where they stand regarding these issues.

In Study II we were unable to control for differences across specific selfidentified ethnicities or gender due to the sample size constraints. So far, there has been very little support in the literature for gender differences regarding ethnic identity factors (e.g., Rivas-Drake et al., 2014a, 2014b; Smith \& Silva, 2011). However, most of the relevant research has used quantitative measures and not examined the actual content of ethnic identity, and most research has been conducted in an American context. Since gender equality has been suggested to be an important part of how Swedes view themselves (e.g., Towns, 2002) and traditional gender role norms are somewhat muted in Sweden (Holmqvist Gattario et al., 2015; Kling et al., 2017; Stavrova et al., 2012), these types of differences are unlikely to be present in the Swedish cultural context (Fadjukoff et al., 2019). However, research on identity in Sweden has demonstrated that there in fact are gender differences connected to identity, which may show that the norms and values of gender equality do not always correspond to people's lived everyday experiences (e.g., Frisén \& Wängqvist, 2011; Frisén, Carlsson, \& Wängqvist, 2014; Magnusson, 2008). Hence, the question remains as to whether gender differences also exist 
regarding ethnic identity. In addition, individuals from a specific ethnic group may be at more risk of being subjected to racism, while individuals from another ethnic group are more at risk of distancing themselves from their culture, ethnicity, or origin, which could be an area for future research. In addition, categorizing immigrant status only in terms of "immigrants" versus "non-immigrants" may reinforce the normative notion in Sweden that people with diverse backgrounds constitute one homogenous group. We therefore tested an additional conceptualization of immigrant status, in which individuals without an immigrant background were grouped with those who had one parent born in Sweden, and individuals who were descendants (i.e., children or grandchildren) of first-generation immigrants constituted another category. The results were the same. This may be because there is a strong emphasis on the concept of "immigrants" as an ascribed position contrasted to "Swedes" (e.g., Johansson \& Olofsson, 2011; SOU, 2005; Svensson et al., 2018), which is likely internalized in people's ethnic identity.

Lastly, as the thematic analyses (Braun \& Clarke, 2006) conducted in studies II and III could have been influenced by coder preconceptions and preunderstandings, multiple coders were involved in the coding process in order to ensure validity. Furthermore, inter-rater reliability was tested with good results. Using a data-driven thematic analysis, as was done in both studies II and III, yields deeper knowledge and broadens our understanding of identity content in Study II and identity structure in Study III, as the participants themselves determined what to share and what they considered most important for them in their lives and as individuals.

\section{Ethical Considerations}

The three studies included in this thesis were ethically reviewed before being conducted, studies I and III by the ethical review board in Gothenburg (Dnr: 263-15) and Study II by the institutional review board at the University of Minnesota. Although ethical considerations for the three studies were carefully taken into account based on the Swedish Ethical Review Act (SFS 2003:460), the Swedish Personal Data Act (SFS 1998:204), and ethical standards derived from the American Psychological Association (see APA, 2002), which require that researchers apply high ethical ideals, some ethical issues nevertheless warrant further discussion.

With the responsibility as a researcher to do good and avoid doing harm, there are always potential risks that participants may be exposed to (Alderson $\&$ Morrow, 2011; APA, 2002). For example, since all three studies in this 
thesis included questions about the participants' lives, thoughts, and feelings, this could create discomfort for some participants. Therefore, the participants were carefully informed of the aims of the studies and how the data would be stored and archived before they gave their informed consent. It was emphasized that participation in the studies was voluntary, that the participants had the right not to answer any question they did not feel comfortable answering, and that they could withdraw from participation at any time. Also, using broad questions that could be answered in many different ways, as was done in all three studies, with a master narrative prompt (Alpert et al., 2014; McLean et al., 2017) being used in Study II and the semi-structured Identity Status Interview (Marcia et al., 1993) being used in studies I and III, allowed the participants to tell their stories as they wanted to tell them.

In addition, the background questions used in Study II, for example, to collect information about gender and ethnicity, were open ended, allowing the participants themselves to define their gender and ethnicity. Giving the participants the possibility of self-definition limits the risk of using only narrow categories of, for example, gender and ethnicity, which could reinforce stereotypical notions of differences. However, due to analytical restrictions, we ended up categorizing the self-definitions and categorizing the participants as either having an immigrant background or not in the analysis. This issue has previously been discussed in this thesis, and it is an issue that is important to emphasize. In a society where ethnic groups are often increasingly pitted against each other, where one might be considered either an immigrant or a Swede, it is particularly important for researchers to reflect on what effects our categorizations of, for example, participants' ethnicity and gender may have, and the signals they send, when conducting and presenting our research. Although it has been argued that being an immigrant or not is an important aspect in understanding social status within Swedish society (de los Reyes, 2005), it is important to acknowledge that people with immigrant backgrounds are not a homogenous group. In addition, although commonly done in research, labeling people as second- or third-generation immigrants, as done in Study II, risks reinforcing racist ideologies in that one can never become Swedish enough. Similar issues can be found in studies I and III, where searching for gender differences risks reinforcing stereotypical gender role norms, even though our findings reinforce the notion, established in psychological research, that there are more similarities than differences between women and men in general (see Halpern, Benbow, Geary, Gur, Hyde, \& Gernbacher, 2007; Hyde, 2005; Magnusson, 2019).

Another issue that merits discussion concerns protecting the anonymity and confidentiality of participants. Although Study II was anonymous and we carefully masked any possible identifying information when selecting the quotations presented, there is still a small risk that someone might recognize 
their own phrases. Studies I and III, on the other hand, being part of a longitudinal project, relied on personal data in order to make recurring contact with the participants. Therefore, great measures have been taken to ensure that the data are handled in accordance with Swedish law (Personal Data Act, SFS 1998:204), in that all personal data are kept separate from other data, from which possible identifiers have been removed. Also, all interviewers were blind to individual data from previous waves, and we tried to ensure that the interviewer had not met the participant in a prior wave of data collection, as that could risk influencing both the interview and the subsequent coding.

In sum, although there were potential risks for the participants stemming from the appended studies, my belief is that the benefits of the research outweighed these risks, due to the measures taken in both planning and conducting the three studies.

\section{Conclusions}

Taken together, the findings of this thesis reflect some of the complex multidimensional aspects of identity in context (Figure 2) and further underline the importance of using an integrated theoretical, as well as methodological, approach to understanding the dimensions of identity process, content, and structure.

The combined results of this thesis reinforce the notion that identity development is a lifelong endeavor in which individuals might follow different trajectories due to factors such as gender and ethnicity and across different identity domains. Furthermore, the findings of this thesis emphasize that identity development is highly dependent on cultural context, underscoring the importance for society of both allowing and encouraging individuals to have multiple identifications, not only through policy, but also by facilitating this in everyday life. More importantly, this thesis highlights the need to take societal norms and expectations into account when exploring identity development and seeking to answer the fundamental question "Who am I?" 


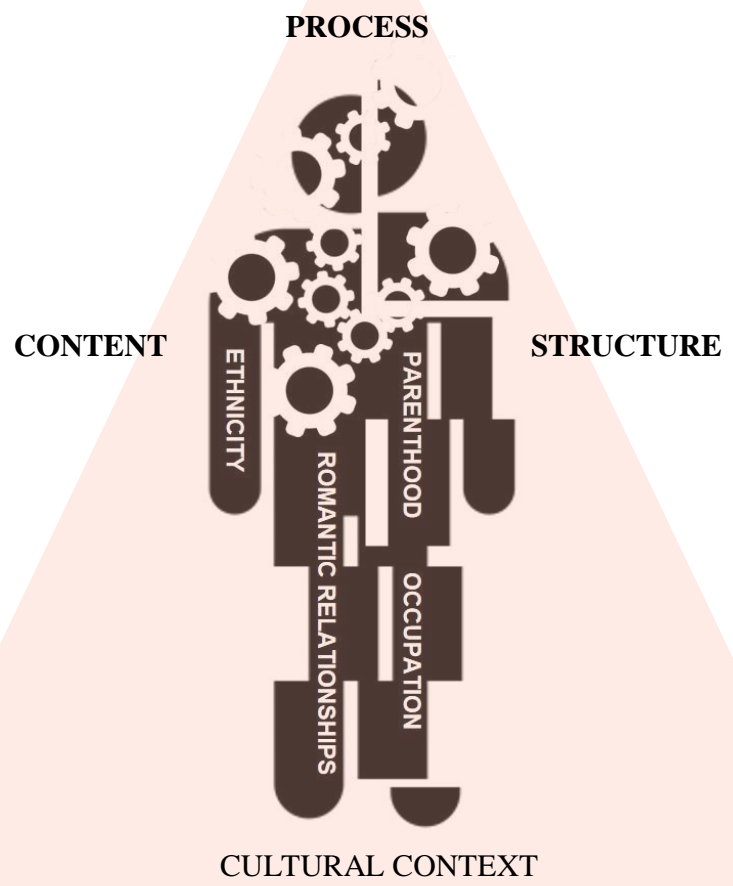

Figure 2. Visualization of the different dimensions of identity.

Do I contradict myself?

Very well then I contradict myself;

(I am large, I contain multitudes.)

Walt Whitman (excerpt from Song of myself, 1855) 


\section{REFERENCES}

Adler, J. M., Dunlop, W. L., Fivush, R., Lilgendahl, J. P., Lodi-Smith, J., McAdams, D. P., . . . Syed, M. (2017). Research Methods for Studying Narrative Identity:A Primer. Social Psychological and Personality Science, 8, 519-527. doi: 10.1177/1948550617698202

Alderson, V., \& Morrow, V. (2011). The ethics of research with children and young people: A practical handbook. Thousand Oaks, CA: SAGE Publications.

Almqvist, K. (2006). Identitet och etnicitet [Identity and ethnicity]. In A. Frisén \& P. Hwang (Eds.), Ungdomar och identitet [Youth and identity] (pp. 79-108). Stockholm, Sweden: Natur och kultur.

Almqvist, A-L., Sandberg, A., \& Dahlgren, L. (2011). Parental leave in Sweden: motives, experiences, and gender equality amongst parents. Fathering, 9, 189-206. doi:10.3149/fth.0902.189

Alpert, L., Marsden, E., Szymanowski, K., \& Lilgendahl, J. P. (2014, February). Feeling different: The roles of social and personality factors in shaping self-defining stories of master narrative deviation experiences. Poster presented at the Annual Meeting of the Society for Personality and Social Psychology, Austin, TX.

American Psychological Association (APA, 2002). Ethical principles of psychologists and code of conduct. American Psychologist, 57, 10601073. doi:10.1037/0003-066X.57.12.1060

Archer, S. L. (1985b). Career and/or family: The identity process for adolescent girls. Youth \& Society, 16, 289-314. doi: 10.1177/0044118X85016003003

Archer, S. L. (1989). Gender differences in identity development: issues of process, domain and timing. Journal of Adolescence, 12, 117-138. doi:10.1016/0140-1971(89)90003-1

Archer, S. L., \& Waterman, A. S. (1988). Psychological individualism: Gender differences or gender neutrality? Human Development, 31, 65-81. doi:10.1159/000275798

Arnett, J. J. (1999). Adolescent storm and stress, reconsidered. American Psychologist, 54, 317-326. doi:10.1037/0003-066X.54.5.317 
Arnett, J. J. (2000). Emerging adulthood: A theory of development from the late teens through the twenties. American Psychologist, 55, 469. doi:10.1037/0003-066X.55.5.469

Arnett, J. J. (2006). Emerging adulthood: Understanding the new way of coming of age. In J. J. Arnett \& J. L. Tanner (Eds.), Emerging adults in America: Coming of age in the 21st century (pp. 3-19). Washington, DC: American Psychological Association.

Arnett, J. J. (2012). New horizons in research on emerging and young adulthood. In A. Both, S. L.Brown, N. S. Landale, W. D. Manning, \& S. M. McHale (Eds.), Early adulthood in a family context (Vol. 2, pp. 231-244). New York, NY: Springer.

Arnett, J. J. (2014). Emerging adulthood: The winding road from the late teens through the twenties (2nd ed.). New York: Oxford University Press.

Arnett, J. J. (2015). Identity development from adolescence to emerging adulthood: What we know and (especially) don't know. In K. C. McLean \& M. Syed (Eds.), The Oxford handbook of identity development (pp. 53-64). New York, NY: Oxford University Press.

Arneaud, M. J., Alea, N., \& Espinet, M. (2016). Identity development in Trinidad: Status differences by age, adulthood transitions, and culture. Identity, 16, 59-71. doi:10.1080/15283488.2015.1121818

Azmitia, M. (2015). Reflections on the cultural lenses of identity development. In K. C. McLean \& M. Syed (Eds.), The Oxford handbook of identity development (pp. 286-296). New York, NY: Oxford University Press.

Azmitia, M., Syed, M., \& Radmacher, K. (2008). On the intersection of personal and social identities: Introduction and evidence from a longitudinal study of emerging adults. New Directions for Child and Adolescent Development, 2008, 1-16. doi:10.1002/cd.212

Barnett, R. C., \& Hyde, J. S. (2001). Women, men, work, and family: An expansionist theory. American Psychologist, 56, 781. doi:10.1037/0003066X.56.10.781

Bauman, Z. (2001). The individualized society. Cambridge, UK: Polity.

Beck, U. (1992). Risk society: Towards a new modernity. Thousand Oaks, CA: SAGE Publications.

Bergh, S., \& Erling, A. (2005). Adolescent identity formation: A Swedish study of identity status using the EOM-EIS-II. Adolescence, 40(158), 377-396. Retrieved from

https://cmapspublic2.ihmc.us/rid=1LPGMZR4Y-2BPPJ2T-

$1 \mathrm{KSQ} /$ identity\%20status.pdf

Berggren, H., \& Trägårdh, L. (2011). Social trust and radical individualism: the paradox at the heart of Nordic capitalism. In Shared norms for the new reality: The Nordic way. World Economic Forum Davos, Stockholm (pp. 13-27). 
Berry, J. W. (1980). Acculturation as varieties of adaptation. In A. M. Pcilla (Ed.). Acculturation: Theories, models, and findings (pp. 9-25). Boulder, CO: Westview.

Berry, J. W., Westin, C., Virta, E., Vedder, P., Rooney, R., \& Sang, D. (2006). Design of the study: Selecting societies of settlements and immigrant groups. In J. W. Berry, J. Phinney, D. L. Sam, \& P. Vedder (Eds.), Immigrant youth in cultural transition (pp. 15-45). Mahwah, NJ: Lawrence Erlbaum.

Berzonsky, M. D. (2011). A social-cognitive perspective on identity construction. In S. J. Schwartz, K. Luyckx \& V. L. Vignoles (Eds.), Handbook of identity theory and research (pp. 55-75). New York, NY: Springer.

Berzonsky, M. D., Macek, P., \& Nurmi, J.-E. (2003). Interrelationships among identity process, content, and structure: A cross-cultural investigation. Journal of Adolescent Research, 18, 112-130. doi:10.1177/0743558402250344

Björnberg, U. (2002). Ideology and choice between work and care: Swedish family policy for working parents. Critical Social Policy, 22, 33-52. doi:10.1177/02610183020220010401

Bohanek, J. G., Marin, K. A., Fivush, R., \& Duke, M. P. (2006). Family narrative interaction and children's sense of self. Family Process, 45, 39-54. doi:10.1111/j.1545-5300.2006.00079.x

Braun, V., \& Clarke, V. (2006). Using thematic analysis in psychology. Qualitative Research in Psychology, 3, 77-101. doi:10.1037/15249220.5.1.40

Broberg, A. (1989). Child care and early development (unpublished doctoral dissertation). Gothenburg, Sweden: Department of Psychology, University of Gothenburg.

Bourne, E. (1978). The state of research on ego identity: A review and appraisal. Part II. Journal of Youth and Adolescence, 7, 371-392. doi:10.1007/bf01537806

Bowleg, L. (2008). When black + lesbian + woman $\neq$ black lesbian woman: The methodological challenges of qualitative and quantitative intersectionality research. Sex Roles, 59, 312-325. doi:10.1007/s11199008-9400-z

Burke, P. J., \& Stets, J. E. (2009). Identity theory. Oxford, UK: Oxford University Press.

Buunk, A. P., \& Gibbons, F. X. (2007). Social comparison: The end of a theory and the emergence of a field. Organizational Behavior and Human Decision Processes, 102, 3-21. doi:10.1016/j.obhdp.2006.09.007 
Carlsson, J., Wängqvist, M., \& Frisén, A. (2015). Identity development in the late twenties: A never ending story. Developmental Psychology, 51, 334. doi: 10.1037/a0038745.supp

Carter, M. (2014). Gender socialization and identity theory. Social Sciences, 3 , 242-263. doi:10.3390/socsci3020242

Chao, R. K., \& Otsuki-Clutter, M. (2011). Racial and ethnic differences: Sociocultural and contextual explanations. Journal of Research on Adolescence, 21, 47-60. doi:10.1111/j.1532-7795.2010.00714.x

Collins, W. A., Welsh, D. P., \& Furman, W. (2009). Adolescent romantic relationships. Annual Review of Psychology, 60, 631-652. doi:10.1146/annurev.psych.60.110707.163459

Côté, J. E. (2015). Identity formation research from a critical perspective: Is a social science developing? In K. C. McLean \& M. Syed (Eds.), The Oxford handbook of identity development (pp. 527-538). New York, NY: Oxford University Press.

Côté, J. E. (2019). Youth development in identity societies: Paradoxes of purpose. New York, NY: Routledge.

Côté, J. E., \& Allahar, A. L. (1994). Generation on hold: Coming of age in the late twentieth century. New York, NY: New York University Press.

Crenshaw, K. (1991). Mapping the margins: Intersectionality, identity politics, and violence against women of color. Stanford Law Review, 43, 12411299. doi: $10.2307 / 1229039$

Crocetti, E., \& Meeus, W. (2015). The identity status: Strengths of a personcentered approach. In K.C. McLean \& M. Syed (Eds.), The Oxford handbook of identity development (pp. 97-114). New York, NY: Oxford University Press.

Crocetti, E., Prati, F., \& Rubini, M. (2018). The interplay of personal and social identity. European Psychologist, 23, 300-310. doi:10.1027/10169040/a000336

Crocetti, E., Rubini, M., \& Meeus, W. (2008). Capturing the dynamics of identity formation in various ethnic groups: Development and validation of a three-dimensional model. Journal of Adolescence, 31, 207-222. doi: 10.1016/j.adolescence.2007.09.002

Crocetti, E., Scrignaro, M., Sica, L. S., \& Magrin, M. E. (2012). Correlates of identity configurations: Three studies with adolescent and emerging adult cohorts. Journal of Youth and Adolescence, 41, 732-748. doi:10.1007/s10964-011-9702-2

Cross, W. E., Jr., \& Cross, T. B. (2008). Theory, research, and models. In S. Quintana \& C. McKown (Eds.) Handbook of race, racism, and child development. (pp. 154-181). New Jersey, NJ: John Wiley and Sons.

Creswell, J.W., \& Plano Clark, V. L. (2007). Designing and conducting mixed methods research. Thousand Oaks, CA: Sage Publications. 
Cole, E. R. (2009). Intersectionality and research in psychology. American Psychologist, 64, 170. doi:10.1037/a0014564

Dahl, A. L., \& Galliher, R. V. (2009). LGBQQ Young Adult Experiences of Religious and Sexual Identity Integration. Journal of LGBT Issues in Counseling, 3, 92-112. doi:10.1080/15538600903005268

Dahl, A., \& Galliher, R. V. (2012). The Interplay of Sexual and Religious Identity Development in LGBTQ Adolescents and Young Adults: A Qualitative Inquiry. Identity, 12, 217-246. doi:10.1080/15283488.2012.691255

Dehlin, J. P., Galliher, R. V., Bradshaw, W. S., \& Crowell, K. A. (2015). Navigating Sexual and Religious Identity Conflict: A Mormon Perspective. Identity, 15, 1-22. doi:10.1080/15283488.2014.989440

Diener, E., Emmons, R. A., Larsen, R. J., \& Griffin, S. (1985). The Satisfaction With Life Scale. Journal of Personality Assessment, 49, 71. doi:10.1207/s15327752jpa4901_13

Diener, E. (2006). Understanding Scores on the Satisfaction with Life Scale. Retrieved from

http://internal.psychology.illinois.edu/ ediener/Documents/Understan ding\% 20SWLS\%20Scores.pdf

Dimitrova, R. (2014). Does your identity make you happy? Collective identifications and acculturation of youth in a post-communist Europe (Doctoral dissertation). Tilburg University, Tilburg, The Netherlands.

Duvander, A.-Z. (2014). How Long Should Parental Leave Be? Attitudes to gender equality, family, and work as determinants of women's and men's parental leave in Sweden. Journal of Family Issues, 35, 909-926. doi:10.1177/0192513x14522242

Elvin-Nowak, Y., \& Thomsson, H. (2001). Motherhood as idea and practice: A discursive understanding of employed mothers in Sweden. Gender \& Society, 15, 407-428. doi:10.1177/089124301015003005

England, P. (2010). The gender revolution: Uneven and stalled. Gender and Society, 24, 149-166. doi:10.1177/0891243210361475

Erikson, E. H. (1950). Childhood and society. New York, NY: Norton.

Erikson, E. H. (1956). The Problem of Ego Identity. Journal of the American Psychoanalytic Association, 4, 56-121. doi: $10.1177 / 000306515600400104$

Erikson, E. H. (1968). Identity: Youth and crisis. New York, NY: Norton.

Erikson, E. H. (1980). Identity and the life cycle. New York, NY: Norton.

Ethical Review Act of 2003, 460 Swedish Law §§1-41. Available from http://www.riksdagen.se/sv/dokument-lagar/dokument/svenskforfattningssamling/lag-2003460-om-etikprovning-av-forskningsom_sfs-2003-460 
European Commission (2019). Your social security rights in Sweden. Brussels:

Directorate-General for Employment, Social Affairs and Inclusion.

European Institute of Gender Equality (2017). Gender equality index and gender statistics. Retrieved from http://eige.europa.eu/gender-statistics

Fadjukoff, P., Feldt, T., Kokko, K., \& Pulkkinen, L. (2019). Identity status change within personal style clusters: A longitudinal perspective from early adulthood to midlife. Identity, 19, 1-17. doi:10.1080/15283488.2019.1566066

Fadjukoff, P., Pulkkinen, L., \& Kokko, K. (2005). Identity processes in adulthood: Diverging domains. Identity, 5, 1-20. doi:10.1207/s1532706xid0501_1

Fadjukoff, P., Pulkkinen, L., \& Kokko, K. (2016). Identity Formation in Adulthood: A Longitudinal Study from Age 27 to 50. Identity, 16, 8-23. doi:10.1080/15283488.2015.1121820

Fagerberg, I., \& Kihlgren, M. (2001). Experiencing a nurse identity: the meaning of identity to Swedish registered nurses 2 years after graduation. Journal of Advanced Nursing, 34, 137-145. doi:10.1046/j.1365-2648.2001.3411725.x

Ferrer-Wreder, L., \& Kroger, J. (2019). Identity in adolescence: The balance between self and other (4th ed.). London, UK: Routledge.

Ferrer-Wreder, L., Trost, K., Lorente, C. C., \& Mansoory, S. (2012). Personal and ethnic identity in Swedish adolescents and emerging adults. New Directions for Child and Adolescent Development, 61-86. doi:10.1002/cad.20022

Festinger, L. (1954). A theory of social comparison processes. Human Relations, 7, 117-140. doi:10.1177/001872675400700202

Fivush, R., Habermas, T., Waters, T. E., \& Zaman, W. (2011). The making of autobiographical memory: Intersections of culture, narratives and identity. International Journal of Psychology, 46, 321-345. doi:10.1080/00207594.2011.596541

Fivush, R., \& Zaman, W. (2015). Gendered narrative voices: Sociocultural and feminist approaches to emerging identity in childhood and adolescence. In K. C. McLean \& M. Syed (Eds.), The Oxford handbook of identity development (pp. 33-52). New York, NY: Oxford University Press.

Frisén, A., Carlsson, J., \& Wängqvist, M. (2014). "Doesn't everyone want that? It's just a given": Swedish 25-year-olds' thoughts and feelings about a future parenthood. Journal of Adolescent Research, 29, 67-88. doi: $10.1177 / 0743558413502537$

Frisén, A., \& Wängqvist, M. (2011). Emerging adults in Sweden: Identity formation in the light of love, work and family. Journal of Adolescent Research, 26, 200-221. doi:10.1177/0743558410376829 
Furlong, A., \& Cartmel, F. (1997). Young people and social change: individualization and risk in late modernity. Buckingham, UK: Open University Press.

Galliher, R. V., McLean, K. C., \& Syed, M. (2017a). An integrated developmental model for studying identity content in context. Developmental Psychology, 2011-2022. doi:http://dx.doi.org/10.1037/dev0000299

Galliher, R. V., Rivas-Drake, D., \& Dubow, E. F. (2017b). Identity development process and content: Toward an integrated and contextualized science of identity. Developmental Psychology, 53, 2009. doi:10.1037/dev0000452

García Coll, C. T., \& Marks, A. K. (Eds.). (2012). The immigrant paradox in children and adolescents: Is Becoming an American a Developmental risk? Washington, DC: American Psychological Association.

Gerber, J., Wheeler, L., \& Suls, J. (2018). A social comparison theory metaanalysis 60+ years on. Psychological Bulletin, 144, 177. doi:10.1037/bul0000127

Gergen, K. J. (1991). The saturated self: Dilemmas of identity in contemporary life. New York, NY: Basic Books.

Gerson, K. (2010). The unfinished revolution: Coming of age in a new era of gender, work, and family. New York, NY: Oxford University Press.

Ghavami, N., Katsiaficas, D., \& Rogers, L. O. (2016). Chapter Two- Toward an intersectional approach in developmental science: The role of race, gender, sexual orientation, and immigrant status. Advances in Child Development and Behavior, 50, 31-73. doi:10.1016/bs .acdb.2015.12.001

Gibbons, F. X., \& Buunk, B. P. (1999). Individual differences in social comparison: Development of a scale of social comparison orientation. Journal of Personality and Social Psychology, 76, 129-142. doi:10.1037/0022-3514.76.1.129

Giddens, A. (1991). Modernity and self-identity: Self and society in the late modern age. Stanford, CA: Stanford University Press.

Goossens, L. (2001). Global versus domain-specific statuses in identity research: A comparison of two self-report measures. Journal of Adolescence, 24, 681-699. doi:10.1006/jado.2001.0438

Grotevant, H. D. (1987). Toward a process model of identity formation. Journal of Adolescent Research, 2, 203-222. doi:10.1177/074355488723003

Grotevant, H. D., Thorbecke, W., \& Meyer, M. L. (1982). An extension of Marcia's Identity Status Interview into the interpersonal domain. Journal of Youth and Adolescence, 11, 33-47. doi:10.1007/bf01537815 
Haas, L., \& Hwang, C. P. (2000). Programs and policies promoting women's economic equality and men's sharing of child care in Sweden. In L. Haas, C. P. Hwang, \& G. Russell (Eds.), Organizational change and gender equity (pp. 133-162). Thousand Oaks, CA: Sage Publications.

Haas, L., \& Hwang, C. P. (2019). Policy is not enough: The influence of the gendered workplace on fathers' use of parental leave in Sweden. Community, Work \& Family, 22, 58-76. doi:10.1080/13668803.2018.1495616

Habermas, T., Ehlert - Lerche, S., \& De Silveira, C. (2009). The development of the temporal macrostructure of life narratives across adolescence: Beginnings, linear narrative form, and endings. Journal of Personality, 77, 527-560. doi:10.1111/j.1467-6494.2008.00557.x

Halpern, D. F., Benbow, C. P., Geary, D. C., Gur, R. C., Hyde, J. S., \&Gernbacher, M. A. (2007). The science of sex differences in science and mathematics. Psychological Science in the Public Interest, 8, 1-51. doi:10.1111/j1529-1006.2007.00032.x

Hammack, P. L. (2008). Narrative and the cultural psychology of identity. Personality and Social Psychology Review, 12, 222-247. doi:10.1177/1088868308316892

Hammack, P. L. (2010). Narrating hyphenated selves: Intergroup contact and configurations of identity among young Palestinian citizens of Israel. International Journal of Intercultural Relations, 34, 368-385. doi:10.1016/j.ijintrel.2010.03.002

Hammack, P. L. (2011). Narrative and the politics of identity: The cultural psychology of Israeli and Palestinian youth. New York, NY: Oxford University Press.

Hammack, P. L., Thompson, E. M., \& Pilecki, A. (2009). Configurations of Identity Among Sexual Minority Youth: Context, Desire, and Narrative. Journal of Youth and Adolescence, 38, 867-883. doi:10.1007/s10964008-9342-3

Helliwell, J. F. Layard, R., \& Sachs, J. D. (2018). World Happiness Report 2018. Retrieved from https://s3.amazonaws.com/happinessreport/2018/WHR_web.pdf

Hellström, A., \& Nilsson, T. (2010). 'We Are the Good Guys': Ideological positioning of the nationalist party Sverigedemokraterna in contemporary Swedish politics. Ethnicities, 10, 55-76. doi:10.1177/1468796809354214

Hogg, M. A. (2000). Subjective uncertainty reduction through selfcategorization: A motivational theory of social identity processes. European Review of Social Psychology, 11, 223-255. doi:10.1080/14792772043000040 
Holmqvist Gattario, K., Frisén, A., Fuller-Tyszkiewicz, M., Ricciardelli, L. A., Diedrichs, P. C., Yager, Z., ... \& Smolak, L. (2015). How is men's conformity to masculine norms related to their body image? Masculinity and muscularity across Western countries. Psychology of Men \& Masculinity, 16, 337. doi:10.1037/a0038494

Hornsey, M. J. (2008). Social identity theory and self - categorization theory: A historical review. Social Personality Psychology Compass, 2, 204222. doi:10.1111/j.1751-9004.2007.00066.x

Huddy, L. (2001). From social to political identity: A critical examination of social identity theory. Political Psychology, 22, 127-156. doi:10.1111/0162-895X.00230

Hultell, D., \& Gustavsson, J. P. (2008). A psychometric evaluation of the Satisfaction with Life Scale in a Swedish nationwide sample of university students. Personality and Individual Differences, 44, 10701079. doi:10.1016/j.paid.2007.10.030

Hyde, J. S. (2005). The gender similarities hypothesis. American Psychologist, 60, 581-592. doi:10.1037/0003-066X.60.6.581

Hylland Eriksen, T. (2004). Rötter och fötter: Identitet $i$ en föränderlig tid [Roots and feet: Identity in a time of change]. Nora, Sweden: Nya Doxa. Iakimova, O. (2018). Exploring the Dynamics of Xenophobia in the Nordic Countries. Changing Societies \& Personalities, 2, 17-31. doi:10.15826/csp.2018.2.1.028

Inglehart, R., Haerpfer, C., Moreno, A., Welzel, C., Kizilova, K., DiezMedrano, J.,...Puranen, B. (Eds.) (2014). World values survey: Round six-country-pooled datafile version: http://www. worldvaluessurvey.org/WVSDocumentationWV6.jsp. Madrid: JD Systems Institute

Jespersen, K., Kroger, J., \& Martinussen, M. (2013). Identity status and moral reasoning: A meta-analysis. Identity, 13, 266-280. doi:10.1080/15283488.2013.799472

Johansson, T., \& Klinth, R. (2008). Caring fathers: The ideology of gender equality and masculine positions. Men and Masculinities, 11, 42-62. doi:10.1177/1097184X06291899.

Johansson, T., \& Olofsson, R. (2011). The art of becoming 'Swedish': Immigrant youth, school careers and life plans. Ethnicities, 11, 184-201. doi: $10.1177 / 1468796811398827$

Josselson, R., \& Harway, M. (Eds.). (2012). Navigating multiple identities: Race, gender, culture, nationality, and roles. Oxford, UK: Oxford University Press. 
Kiang, L., Yip, T., \& Fuligni, A. J. (2008). Multiple social identities and adjustment in young adults from ethnically diverse backgrounds. Journal of Research on Adolescence, 18, 643-670. doi:10.1111/j.15327795.2008.00575.x

Kierkegaard, S. (1944). Concluding unscientific postscript. Princeton, NJ: Princeton University Press.

Kling, J., Holmqvist Gattario, K., \& Frisén, A. (2017). Swedish women's perceptions of and conformity to feminine norms. Scandinavian Journal of Psychology, 58, 238-248. doi:10.1111/sjop.12361

Kling, J., Wängqvist, M., \& Frisén, A. (2018). “This body is me” Discovering the ways in which the body is salient in people's identities. Body Image, 24, 102-110. doi: 10.1016/j.bodyim.2017.12.009

Kroger, J. (1997). Gender and identity: The intersection of structure, content, and context. Sex Roles, 36, 747-770. doi:10.1023/a:1025627206676

Kroger, J. (2003). What transits in an identity status transition? Identity, 3, 197-220. doi:10.1207/S1532706XID0303_02

Kroger, J. (2007). Identity development: Adolescence through adulthood (2nd ed.). Thousand Oaks, CA: Sage.

Kroger, J. (2015). Identity development through adulthood: The move toward "wholeness." In K. C. McLean \& M. Syed (Eds.), The Oxford handbook of identity development (pp. 65-80). New York, NY: Oxford University Press.

Kroger, J., \& Marcia, J. E. (2011). The identity statuses: Origins, meanings, and interpretations. In S. J. Schwartz, K. Luyckx, \& V. L. Vignoles (Eds.), Handbook of identity theory and research (Vol. 1, pp. 31-53). New York, NY: Springer.

Kroger, J., Martinussen, M., \& Marcia, J. E. (2010). Identity status change during adolescence and young adulthood: A meta-analysis. Journal of Adolescence, 33, 683-698. doi:10.1016/j.adolescence.2009.11.002

Lalander, P., \& Johansson, T. (2008). Ungdomsgrupper i teori och praktik [Youth groups in theory and practice] (3rd ed.). Lund, Sweden: Studentlitteratur.

Lewis, H. L. (2003). Differences in ego identity among college students across age, ethnicity, and gender. Identity, 3, 159-189. doi:10.1207/S1532706XID030205

Liedman, S-E. (1999). Att se sig själv i andra: Om solidaritet [To see yourself in others: About solidarity]. Stockholm, Sweden: Bonnier Essä.

Lillevoll, K. R., Kroger, J., \& Martinussen, M. (2013). Identity status and locus of control: A meta-analysis. Identity, 13, 253-265. doi:10.1080/15283488.2013.799471 
Lunde, C., \& Gyberg, F. (2016). Maternal and paternal influences on young Swedish women's and men's cosmetic surgery acceptance. Sex Roles, 74, 242-253. doi:10.1007/s11199-015-0574-x

Luyckx, K., Goossens, L., \& Soenens, B. (2006). A developmental contextual perspective on identity construction in emerging adulthood: Change dynamics in commitment formation and commitment evaluation. Developmental Psychology, 42, 366. doi:10.1037/0012-1649.42.2.366

Luyckx, K., Goossens, L., Soenens, B., \& Beyers, W. (2006). Unpacking commitment and exploration: Preliminary validation of an integrative model of late adolescent identity formation. Journal of Adolescence, 29, 361-378. doi:10.1016/j.adolescence.2005.03.008

Luyckx, K., Seiffge-Krenke, I., Schwartz, S. J., Crocetti, E., \& Klimstra, T. A. (2014). Identity configurations across love and work in emerging adults in romantic relationships. Journal of Applied Developmental Psychology, 35, 192-203. doi: 10.1016/j.appdev.2014.03.007

Magnusson, E. (2008). Conflict, danger and difference: Nordic heterosexual couples converse about gender equality and fairness. In E. Magnusson, M. Rönnblom, \& H. Silius (Eds.), Critical studies of gender equalities: Nordic dislocations, dilemmas and contradictions (pp. 161-177). Gothenburg, Sweden, Makadam.

Magnusson, E. (2019). Könstillhörighet: Förklaringar, normer, betydelser [Gender: Explanations, norms, meanings]. Stockholm, Sweden: Natur \& Kultur.

Marcia, J. E. (1966). Development and validation of ego-identity status. Journal of Personality and Social Psychology, 3, 551-558. doi:10.1037/h0023281

Marcia, J. E. (1993). The ego identity status approach to ego identity. In J. E. Marcia, A. S. Waterman, D. R. Matteson, S. L. Archer, \& J. L. Orlofsky (Eds.), Ego identity: A handbook for psychosocial research (pp. 3-21). New York, NY: Springer.

Marcia, J. E. (2001). A commentary on Seth Schwartz's review of identity theory and research. Identity, 1, 59-65. doi:10.1207/S1532706XMARCIA

Marcia, J. E., Waterman, A. S., Mattesson, D. R., Archer, S. L., \& Orlofsky, J. L. (Eds.). (1993). Ego identity. A handbook for psychosocial research. New York, NY: Springer-Verlag.

McAdams, D. P. (1993). The stories we live by: Personal myths and the making of the self. New York, NY: Morrow.

McAdams, D. P. (2001). The psychology of life stories. Review of General Psychology, 5, 100-122. doi:10.1037/1089-2680.5.2.100 
McAdams, D. P. (2011). Narrative identity. In S. J. Schwartz, K. Luyckx, \& V. L. Vignoles (Eds.), Handbook of identity theory and research (Vol. 1, pp. 99-115). New York, NY: Springer.

McAdams, D. P. (2015). The art and science of personality development. New York, NY: Guilford Press.

McAdams, D. P., \& McLean, K. C. (2013). Narrative identity. Current Directions in Psychological Science, 22, 233-238. doi:10.1177/0963721413475622

McAdams, D. P., \& Zapata-Gietl, C. (2015). Three strands of identity development across the human life course: Reading Erik Erikson in full. In K. C. McLean \& M. Syed (Eds.), The Oxford handbook of identity development (pp. 81-94). New York, NY: Oxford University Press.

McCall, L. (2005). The complexity of intersectionality. Signs, 30, 1771-1800. doi:10.1086/426800

McLean, K. C. (2015). The co-authored self: Family stories and the construction of personal identity. New York, NY: Oxford University Press.

McLean, K. C., Boggs, S., Haraldsson, K., Lowe, A., Fordham, C., Byers, S., \& Syed, M. (2019). Personal identity development in cultural context: The socialization of master narratives about the gendered life course. International Journal of Behavioral Development. doi: $10.1177 / 0165025419854150$

McLean, K. C., \& Fournier, M. A. (2008). The content and processes of autobiographical reasoning in narrative identity. Journal of Research in Personality, 42, 527-545. doi:10.1016/j.jrp.2007.08.003

McLean, K. C., Lilgendahl, J. P., Fordham, C., Alpert, E., Marsden, E., Szymanowski, K., \& McAdams, D. P. (2018). Identity development in cultural context: The role of deviating from master narratives. Journal of Personality, 86, 631- 651. doi:10.1111/jopy.12341

McLean, K. C., Shucard, H., \& Syed, M. (2017). Applying the master narrative framework to gender identity development in emerging adulthood. Emerging Adulthood, 5, 93-105. doi: 10.1177/2167696816656254

McLean, K. C., Syed, M., \& Shucard, H. (2016). Bringing identity content to the fore: Links to identity development processes. Emerging Adulthood, 4, 356-364. doi: 10.1177/2167696815626820

McLean, K. C., Syed, M., Yoder, A., \& Greenhoot, A. F. (2016). The role of domain content in understanding identity development processes. Journal of Research on Adolescence, 26, 60-75. doi:10. 1111/jora.12169

Meeus, W. (2011). The study of adolescent identity formation 2000-2010: A review of longitudinal research. Journal of Research on Adolescence, 21,75-94. doi:10.1111/j.1532-7795.2010.00716.x 
Meeus, W., Deković, M., \& Iedema, J. (1997). Unemployment and identity in adolescence: A social comparison perspective. The Career Development Quarterly, 45, 369-380. doi:10.1002/j.2161-0045.1997.tb00540.x

Meeus, W., Van De Schoot, R., Keijsers, L., Schwartz, S. J., \& Branje, S. (2010). On the Progression and Stability of Adolescent Identity Formation: A Five-Wave Longitudinal Study in Early-to-Middle and Middle-to-Late Adolescence. Child Development, 81, 1565-1581. doi:10.1111/j.1467-8624.2010.01492.x

Meier, A., \& Allen, G. (2009). Romantic relationships from adolescence to young adulthood: Evidence from the national longitudinal study of adolescent health. The Sociological Quarterly, 50, 308-335. doi:10.1111/j.1533-8525.2009.01142.x

Mettee, D. R., \& Smith, G. (1977). Social comparison and interpersonal attraction: The case for dissimilarity. In J. M. Suls \& R. L. Miller (Eds.), Social comparison processes: Theoretical and empirical perspectives (pp. 69-101). Washington, DC: Hemisphere.

Merrill, N., \& Fivush, R. (2016). Intergenerational narratives and identity across development. Developmental Review, 40, 72-92. doi: 10.1016/j.dr.2016.03.001

MIPEX (2015). Migrant Integration Policy Index 2015. Retrieved from http://www.mipex.eu/

Moon, C. (2008). Sweden: The secret files (what they would rather keep to themselves). Uppsala: Wikströms.

Motti-Stefanidi, F. (2015). Identity development in the context of the risk and resilience framework. In K. C. McLean \& M. Syed (Eds.), The Oxford handbook of identity development (pp. 472-489). New York, NY: Oxford University Press.

Nelson, S. C., Kling, J., Wängqvist, M., Frisén, A., \& Syed, M. (2018). Identity and the body: Trajectories of body esteem from adolescence to emerging adulthood. Developmental Psychology, 54, 1159. doi:10.1037/dev0000435

Pascoe, E. A., \& Smart Richman, L. (2009). Perceived discrimination and health: A meta-analytic review. Psychological Bulletin, 135, 531. doi:10.1037/a0016059

Pasupathi, M. (2014). Identity development: Dialogue between normative and pathological developmental approaches. Journal of Personality Disorders, 28, 113-20. doi: 101521pedi2014281113

Pavot, W., \& Diener, E. (2009). Review of the Satisfaction With Life Scale. In E. Diener (Ed.), Assessing Well-Being: The Collected Works of Ed Diener (pp. 101-117). Dordrecht: Springer Netherlands. 
Personal Data Act of 1998, 204 Swedish Law §§1-53. Available from http://www.riksdagen.se/sv/dokument-lagar/dokument/svenskforfattningssamling/personuppgiftslag-1998204_sfs-1998-204

Phinney, J. S. (1990). Ethnic identity in adolescents and adults: Review of research. Psychological Bulletin, 108, 499-514. doi:10.1037/00332909.108.3.499

Phinney, J. (1993). A three-stage model of ethnic identity development. In M. Bernal \& G. Knight (Eds.), Ethnic identity: Formation and transmission among Hispanics and other minorities (pp. 61-79). Albany, NY: State University of New York Press.

Phinney, J. S. (2000). Identity formation across cultures: The interaction of personal, societal, and historical change. Human Development, 43, 2731. doi:10.1159/000022653

Phinney, J. S. (2003). Ethnic identity and acculturation. In K. M. Chun, P. B. Organista, \& G.Marı'n (Eds.), Acculturation: Advances in theory, measurement, andapplied research (pp. 63-81). Washington, DC: American Psychological Association.

Phinney, J. S. (2006). Ethnic identity exploration in emerging adulthood. In J. J. Arnett \& J. L. Tanner (Eds.), Emerging adulthood: Coming of age in the 21st century (pp. 117-134). Washington, DC: American Psychological Association.

Phinney, J. S., \& Ong, A. D. (2007). Conceptualization and measurement of ethnic identity: Current status and future directions. Journal of Counseling Psychology, 54, 271. doi:10.1037/0022-0167.54.3.271

Phinney, J. S., Ong, A., \& Madden, T. (2000). Cultural values and intergenerational value discrepancies in immigrant and non - immigrant families. Child Development, 71, 528-539. doi:10.1111/14678624.00162

Pulkkinen, L., \& Kokko, K. (2000). Identity development in adulthood: A longitudinal study. Journal of Research in Personality, 34, 445-470. doi:10.1006/jrpe.2000.2296

Quintana, S. M. (2007). Racial and ethnic identity: Developmental perspectives and research. Journal of Counseling Psychology, 54, 259270. doi:10.1037/0022-0167.54.3.259

Rivas-Drake, D., Seaton, E. K., Markstrom, C., Quintana, S., Syed, M., Lee, R. M., . . Y Yip, T. (2014a). Ethnic and racial identity in adolescence: implications for psychosocial, academic, and health outcomes. Child Development, 85, 40-57. doi:10.1111/cdev.12200

Rivas-Drake, D., Syed, M., Umaña-Taylor, A. J., Markstrom, C., French, S., Schwartz, S. J., \& Lee, R. M. (2014b). Feeling good, happy, and proud: A meta-analysis of positive ethnic-racial affect and adjustment. Child Development, 85, 77-102. doi:10.1111/cdev.12175 
Rogers, L. O. (2018). "Who am I, who are we? Erikson and a transactional approach to identity research." Identity, 1-11. doi:10.1080/15283488.2018.1523728

Ryeng, M. S., Kroger, J., \& Martinussen, M. (2013). Identity status and authoritarianism: A meta-analysis. Identity, 13, 242-252. doi:10.1080/15283488.2013.799434

Sam, D. L., \& Berry, J. W. (2010). Acculturation: When individuals and groups of different cultural backgrounds meet. Perspectives on Psychological Science, 5, 472-481. doi:10.1177/1745691610373075

Schachter, E. P. (2004). Identity configurations: A new perspective on identity formation in contemporary society. Journal of Personality, 72, 167-200. doi:10.1111/j.0022-3506.2004.00260.x

Schachter, E. P. (2005a). Context and Identity formation a theoretical analysis and a case study. Journal of Adolescent Research, 20, 375-395. doi: $10.1177 / 0743558405275172$

Schachter, E. P. (2005b). Erikson meets the postmodern: Can classic identity theory rise to the challenge? Identity, 5, 137-160. doi:10.1207/s1532706xid0502_4

Schachter, E. P. (2013). Multiple identities as viewed by Eriksonian theory and its critics: A psychological perspective with relevance to contemporary Jewish education. International Journal of Jewish Education and Research, 2013(5-6), 71-90. Retrieved from https://www.biu.ac.il/soc/ijjer/5_6_issue.html

Shirai, T., Nakamura, T., \& Katsuma, K. (2016). Identity development in relation to time beliefs in emerging adulthood: A long-term longitudinal study. Identity, 16, 45-58. doi:10.1080/15283488.2015.1121817

Schwartz, S. J. (2001). The evolution of Eriksonian and, neo-Eriksonian identity theory and research: A review and integration, Identity, 1, 7-58, doi:10.1207/S1532706XSCHWARTZ

Schwartz, S. J., Beyers, W., Luyckx, K., Soenens, B., Zamboanga, B. L., Forthun, L. F., . . . Waterman, A. S. (2011). Examining the light and dark sides of emerging adults' identity: A study of identity status differences in positive and negative psychosocial functioning. Journal of Youth and Adolescence, 40, 839-859. doi:10.1007/s10964-010-96066

Schwartz, S. J., Luyckx, K., \& Crocetti, E. (2015). What have we learned since Swhartz (2001)? A reappraisal of the field of identity development. In K. C. McLean \& M. Syed (Eds.), Oxford handbook of identity development (pp. 539-561). New York, NY: Oxford University Press. 
Schwartz, S. J., Syed, M., Yip, T., Knight, G. P., Umaña-Taylor, A. J., RivasDrake, D., \& Lee, R. M. (2014). Methodological issues in ethnic and racial identity research with ethnic minority populations: Theoretical precision, measurement issues, and research designs. Child Development, 85, 58-76. doi:10.1111/cdev.12201

Schierup, C.-U., Ålund, A., \& Neergaard, A. (2018). "Race" and the upsurge of antagonistic popular movements in Sweden. Ethnic and Racial Studies, 41, 1837-1854. doi:10.1080/01419870.2017.1361541

Scuzzarello, S., \& Carlson, B. (2018). Young Somalis' social identity in Sweden and Britain. The interplay of group dynamics, socio-political environments, and transnational ties in social identification processes. Migration Studies, mny013. doi:10.1093/migration/mny013

Simpson, B., \& Carroll, B. (2008). Re-viewing 'Role' in Processes of Identity Construction. Organization, 15, 29-50. doi: $10.1177 / 1350508407084484$

Smith, T. B., \& Silva, L. (2011). Ethnic identity and personal well-being of people of color: A meta-analysis. Journal of Counseling Psychology, 58, 42. doi:10.1037/a0021528

Sommestad, L. (1997). Welfare state attitudes to the male breadwinning system: The United States and Sweden in comparative perspective. International Review of Social History, 42, 153-174. doi:10.1017/S0020859000114828

SOU (2005). Det blågula glashuset: Strukturell diskriminering i Sverige [The blue and yellow glasshouse: Structural discrimination in Sweden] (No. 2005:56). Stockholm, Sweden: Government Office.

Spears, R. (2011). Group identities: The social identity perspective. In J. S. Schwartz, K. Luyckx, \& L. V. Vignoles (Eds.), Handbook of Identity Theory and Research (pp. 201-224). New York, NY: Springer.

Statistics Sweden (SCB, 2018). På tal om kvinnor och män. Lathund för jämställdhet 2018 [Women and men in Sweden 2018. Facts and figures]. Retrieved from http://www.scb.se/en_/Finding-statistics/Publishingcalendar/Show-detailed-information/?publobjid=27674

Statistics Sweden (SCB, 2019a). [Interactive table of population statistics in Sweden 2018, Swedish/Foreign background]. Retrieved from http://www.statistikdatabasen.scb.se

Statistics Sweden (SCB, 2019b). Utrikes födda efter födelseland och invandringsår 2018 [Foreign born after birth country and year of immigration 2018]. Retrieved from https://www.scb.se/hittastatistik/statistik-efter-amne/befolkning/befolkningenssammansattning/befolkningsstatistik/pong/tabell-ochdiagram/helarsstatistik--riket/invandring-till-sverige-efter-de-20vanligaste-fodelselanderna-for-de-invandrade/ 
Statistics Sweden (SCB, 2019c). [Interactive tables of population statistics in Sweden 2018, Mean age first child and Employment]. Retrieved from http://www.statistikdatabasen.scb.se.

Statistics Sweden (SCB, 2019d). Labour Force Survey 2018. Retrieved from https://www.scb.se/en/finding-statistics/statistics-by-subjectarea/labour-market/labour-force-surveys/labour-force-surveyslfs/pong/publications/labour-force-surveys-lfs-2018/

Stavrova, O., Fetchenhauer, D., \& Schlösser, T. (2012). Cohabitation, gender, and happiness: A cross-cultural study in thirty countries. Journal of Cross-Cultural Psychology, 43, 1063-1081. doi:10.1177/0022022111419030.

Steinberg, L. (2014). Adolescence (10 $0^{\text {th }}$ ed.). New York, NY: McGraw-Hill.

St. Louis, G. R., \& Liem, J. H. (2005). Ego identity, ethnic identity, and the psychosocial well-being of ethnic minority and majority college students. Identity, 5, 227-246. doi:10.1207/s1532706xid0503_1

Stryker, S. (2008). From Mead to a structural symbolic interactionism and beyond. Annual Review of Sociology, 34, 15-31. doi:10.1146/annurev.soc.34.040507.134649

Svensson, Y., Berne, J., \& Syed, M. (2018). A narrative approach to the role of others in ethnic identity formation. Cultural Diversity and Ethnic Minority Psychology, 24, 187-195. doi:10.1037/cdp0000182

Svensson, Y., \& Syed, M. (2019). Linking self and society: Identity and the immigrant experience in two macro-contexts. Journal of Applied Developmental Psychology, 64, 101056.

doi:10.1016/j.appdev.2019.101056

Swedish Migration Agency (2019). Historik [History]. Retrieved from https://www.migrationsverket.se/Om-Migrationsverket/Migration-tillSverige/Historik.html

Swedish Social Insurance Agency (2018). Social insurance in figures 2018. Retrieved from https://www.forsakringskassan.se/wps/wcm/connect/9d2fe83d-f16f4321-b583-9cef8362320b/social forsakringen-i-siffror-2018engelsk.pdf?MOD=AJPERES $\&$ CVID $=$

Syed, M. (2010). Developing an integrated self: Academic and ethnic identities among ethnically diverse college students. Developmental Psychology, 46, 1590-1604. doi:10.1037/a0020738

Syed, M. (2015). Theoretical and methodological contributions of narrative psychology to ethnic identity research. In C. E. Santos \& A. J. UmañaTaylor (Eds.) Studying ethnic identity: Methodological and conceptual approaches across disciplines (pp. 27-54). Washington, DC: American Psychological Association. 
Syed, M. (2017). Advancing the cultural study of personality and identity: models, methods, and outcomes. Current Issues in Personality Psychology, 5, 65-72. doi:10.5114/cipp.2017.66604

Syed, M., \& Ajayi, A. A. (2018). Promises and pitfalls in the integration of intersectionality with development science. New Directions for Child and Adolescent Development, 161, 109- 117. doi:10.1002/cad.20250

Syed, M., \& Azmitia, M. (2008). A narrative approach to ethnic identity in emerging adulthood: Bringing life to the identity status model. Developmental Psychology, 44, 1012-1027. doi:10.1037/00121649.44.4.1012

Syed, M., \& Azmitia, M. (2010). Narrative and ethnic identity exploration: A longitudinal account of emerging adults' ethnicity-related experiences. Developmental Psychology, 46, 208-219. doi:10.1037/a0017825

Syed, M., \& Fish, J. (2018). Revisiting Erik Erikson's Legacy on Culture, Race, and Ethnicity. Identity, 18, 274-283. doi:10.1080/15283488.2018.1523729

Syed, M., \& Juang, L. P. (2014). Ethnic identity, identity coherence, and psychological functioning: Testing basic assumptions of the developmental model. Cultural Diversity Ethnic Minority Psychology, 20, 176. doi: $10.1037 / \mathrm{a} 0035330$

Syed, M., \& McLean, K. (2015). The future of identity development research: Reflections, tensions, and challenges. In K. McLeans \& M. Syed (Eds.), The Oxford handbook of identity development (pp. 562-573). New York: Oxford University Press.

Syed, M., \& McLean, K. C. (2016). Understanding identity integration: Theoretical, methodological, and applied issues. Journal of Adolescence, 47, 109-118. doi:10.1016/j.adolescence.2015.09.005

Syed, M., \& Mitchell, L. L. (2013). Race, ethnicity, and emerging adulthood: Retrospect and prospects. Emerging Adulthood, 1, 83-95. doi: $10.1177 / 2167696813480503$

Tajfel, H., \& Turner, J. C. (1979). An integrative theory of intergroup conflict. In W. G. Austin \& S. Worchel (Eds.), The social psychology of intergroup relations (pp. 33-47). Monterey, CA: Brooks/Cole.

Tajfel, H., \& Turner, J. C. (1986). An integrative theory of intergroup relations. In S. Worchel \& W. G. Austin (Eds.), The psychology of intergroup relations (pp. 7-24). Chicago, IL: Nelson-Hall.

Teddlie, C., \& Tashakkori, A. (Eds.). (2010). Sage handbook of mixed methods in social and behavioral research (2nd ed.). Thousand Oaks, CA: Sage.

Thorne, A. (2004). Putting the person into social identity. Human Development, 47, 361-361. doi:10.1159/000081038 
Towns, A. (2002). Paradoxes of (in)equality: Something is rotten in the gender equal state of Sweden. Cooperation and Conflict, 37,157-180. doi: $10.1177 / 0010836702037002975$.

Towns, A., Karlsson, E., \& Eyre, J. (2014). The equality conundrum: Gender and nation in the ideology of the Sweden Democrats. Party Politics, 20, 237-247. doi:10.1177/1354068813520272

Trägårdh, L. (1990). Swedish model or Swedish culture? Critical Review, 4 , 569-590. doi:10.1080/08913819008459622

Turner, J. C. (1975). Social comparison and social identity: Some prospects for intergroup behaviour. European Journal of Social Psychology, 5, 1-34. doi:10.1002/ejsp.2420050102

Turner, J. C., \& Reynolds, K. J. (2012). Self-categorization theory. In P. A. M. Van Lange, A. W. Kruglanski, \& E. T. Higgins (Eds.), Handbook of theories of social psychology (Vol. 2, pp. 399-417). Thousand Oaks, CA: Sage.

Umaña-Taylor, A. J., Quintana, S. M., Lee, R. M., Cross, W. E., Rivas-Drake, D., Schwartz, S. J., Syed, M., Yip, T., Seaton, E. (2014). Ethnic and racial identity revisited: An integrated conceptualization. Child Development, 85, 21-39. doi:10.1111/cdev.12196

van Doeselaar, L., Becht, A. I., Klimstra, T. A., \& Meeus, W. H. J. (2018). A review and integration of three key components of identity development: Distinctiveness, coherence, and continuity. European Psychologist, 23, 278-288. doi:10.1027/1016-9040/a000334

van Hoof, A. (1999). The identity status field re-reviewed: An update of unresolved and neglected issues with a view on some alternative approaches. Developmental Review, 19, 497-556. doi:10.1006/drev.1999.0484

Vedder, P., \& Virta, E. (2005). Language, ethnic identity, and the adaptation of Turkish immigrant youth in the Netherlands and Sweden. International Journal of Intercultural Relations, 29, 317-337. doi:10.1016/j.ijintrel.2005.05.006

Verkuyten, M. (2018). The social psychology of ethnic identity (2nd ed.). London, UK: Routledge.

Virta, E., Sam, D. L., \& Westin, C. (2004). Adolescents with Turkish background in Norway and Sweden: A comparative study of their psychological adaptation. Scandinavian Journal of Psychology, 45, 1525. doi:10.1111/j.1467-9450.2004.00374.x

Waterman, A. S. (1999). Identity, the identity statuses, and identity status development: A contemporary statement. Developmental Review, 19, 591-621. doi:10.1006/drev.1999.0493

Way, N., \& Rogers, O. (2015). “[T]hey say black men won't make it, but I know I'm gonna make it": Ethnic and racial identity development in the 
context of cultural stereotypes. In K. McLeans \& M. Syed (Eds.), The Oxford handbook of identity development (pp. 269-285). New York, NY: Oxford University Press.

Whitbourne, S. K., Sneed, J. R., \& Skultety, K. M. (2002). Identity processes in adulthood: Theoretical and methodological challenges. Identity, 2, 29-45. doi:10.1207/S1532706XID0201_03

Whitman, W. (1855). Leaves of grass. Middlesex, UK: Penguin Books.

Wickström, M. (2013). Conceptual change in postwar Sweden: The marginalization of assimilation and the introduction of integration. In P. Kivisto \& Ö. Wahlbeck (Eds.), Debating multiculturalism in the Nordic welfare states (pp. 110-139). London: Palgrave Macmillan.

Wigg, U. (2008). Bryta upp och börja om: Berättelser om flyktingskap, skolgång och identitet [Being up-rooted and starting over: Stories about being a refugee, schooling and identity] (Doctoral thesis, Linköping University, Linköping, Sweden). Retrieved from http://liu.divaportal.org/smash/get/diva2:133426/FULLTEXT02.pdf

Wikström, H. (2007). (O)möjliga positioner: Familjer från Iran \& postkoloniala reflektioner [(Im)possible positions: Families from Iran \& postcolonial reflections] (Doctoral thesis, University of Gothenburg, Gothenburg, Sweden). $\quad$ Retrieved from https://gupea.ub.gu.se/bitstream/2077/10308/1/gupea_2077_10308_1.p df

Wissink, I. B., Deković, M., Yağmur, Ş., Stams, G. J., \& de Haan, M. (2008). Ethnic identity, externalizing problem behaviour and the mediating role of self-esteem among Dutch, Turkish-Dutch and Moroccan-Dutch adolescents. Journal of Adolescence, 31, 223-240. doi: 10.1016/j.adolescence.2007.12.002

Woolf, V. (1931). The waves. London, UK: Hogarth Press

World Economic Forum (2018). The global gender gap report 2018. Retrieved from http://www3.weforum.org/docs/WEF_GGGR_2018.pdf

World Values Survey. (WVS, 2015). Retrieved from http://www.worldvaluessurvey.org/wvs

Worrell, F.C. (2015). Culture as race/ethnicity. In K. McLeans \& M. Syed (Eds.), The Oxford handbook of identity development (pp. 249-268). New York, NY: Oxford University Press.

Wängqvist, M., Carlsson, J., van der Lee, M., \& Frisén, A. (2016). Identity development and romantic relationships in the late twenties. Identity, 16, 24-44. doi:10.1080/15283488.2015.1121819

Wängqvist, M., \& Frisén, A. (2013). Swedish 18-year-olds' identity formation: Associations with feelings about appearance and internalization of body ideals. Journal of Adolescence, 36, 485-493. doi:10.1007/978-1-46141436-0_15 


\section{APPENDIX}

I. Gyberg, F., \& Frisén, A. (2017). Identity status, gender, and social comparison among young adults. Identity, 17, 239-252. doi:10.1080/15283488.2017.1379905

II. Gyberg, F., Frisén, A., Syed, M., Wängqvist, M., \& Svensson, Y. (2018). "Another kind of Swede": Swedish youth's ethnic identity narratives. Emerging Adulthood, 6, 17-31.

doi: $10.1177 / 2167696817690087$

III. Gyberg, F., Frisén, A., \& Syed, M. (2019). "Being stuck between two worlds": Identity configurations of occupational and family identities. Provisional acceptance in Identity. 